Historic, archived document

Do not assume content reflects current scientific knowledge, policies, or practices. 

C 2 states

Agriculture

Forest

Service

North Central

Forest Experiment

Station

Resource

Bulletin NC-73

[4⿻肀二
Timber Resource of Wisconsin's Northwest Survey Unit, 1983

W. Brad Smith

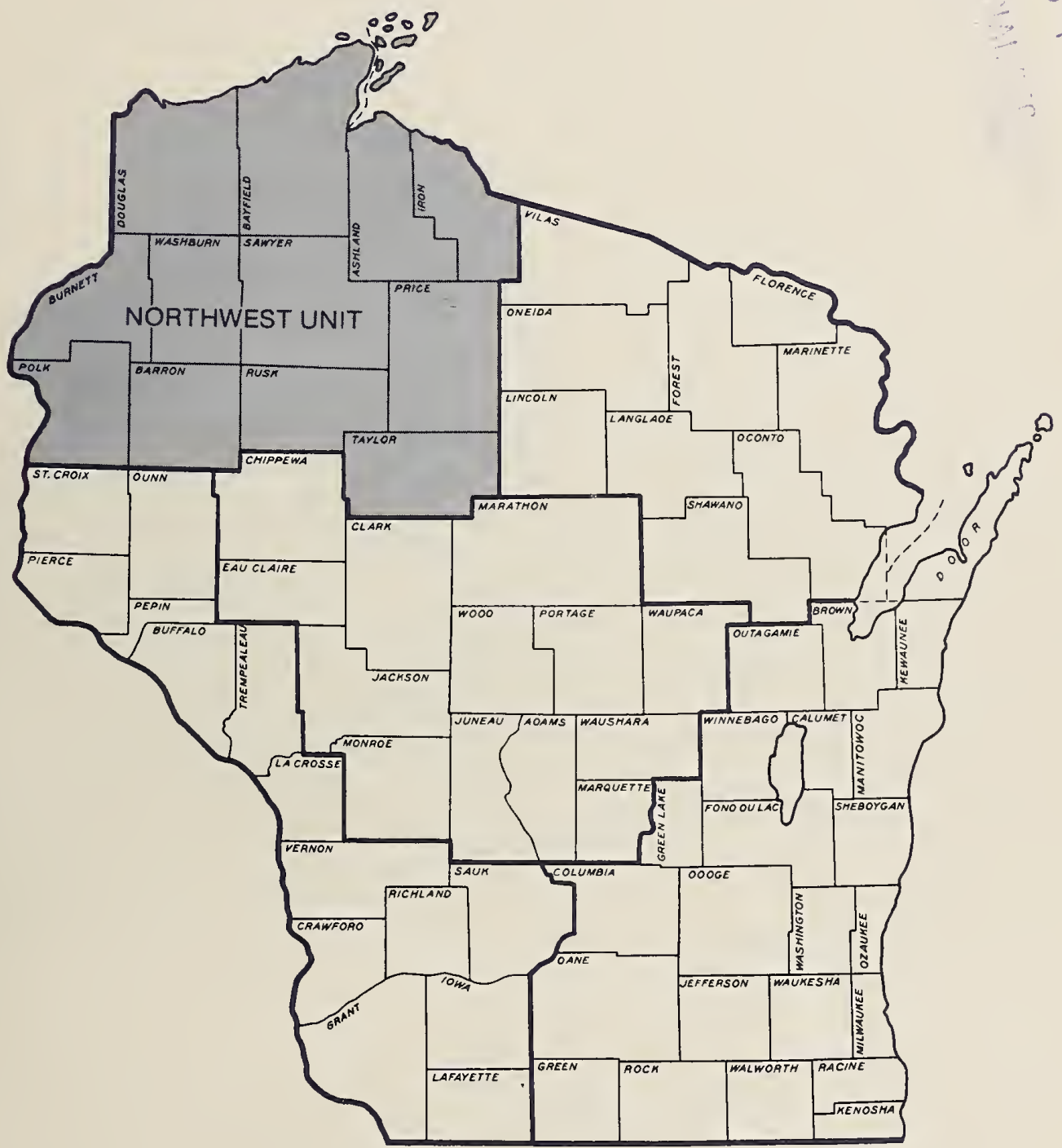

r. 
Information contained in this report includes the most commonly used Forest Inventory and Analysis statistics. However, additional forest resource data can be provided to interested users. Persons requesting additional information that can be provided from the raw inventory data are expected to pay for the retrieval costs. These costs will vary depending on the complexity of the request, from less than $\$ 100$ for a relatively simple request to $\$ 2,000$ for a complex retrieval involving services of a Forest Inventory and Analysis computer programmer. If requests for data conflict with ongoing Forest Inventory and Analysis work, they will be scheduled so as to minimize the impact on the work unit.

Requests for unpublished information may be directed to:

Burton L. Essex

Forest Inventory and Analysis Project

North Central Forest Experiment Station

1992 Folwell Avenue

St. Paul, Minnesota 55108

Phone: (612) 642-5282

Area served: Illinois, Indiana, Iowa, Kansas, Michigan, Minnesota, Missouri, Nebraska, North Dakota, eastern South Dakota, Wisconsin.

North Central Forest Experiment Station

Forest Service - U.S. Department of Agriculture

1992 Folwell Avenue

St. Paul, Minnesota 55108

Manuscript approved for publication December 16, 1983

June 1984 


\section{FOREWORD}

Forest Inventory and Analysis (FIA) is a continuing endeavol as mandated by the Renewable Forest and Rangeland Resources Planning Act of 1974. Prior inventories were mandated by the MeSweeney-MeNary Forest Research Act of 1928. The objective of FIA is to periodically inventory the Nation's forest land to determine its extent, condition, and volume of timber, growth, and depletions. Up-to-date resource information is essential to frame intelligent forest policies and programs. USDA Forest Service regional experiment stations are responsible for conducting these inventories and publishing summary reports for individual States. The North Central Forest Experiment Station is responsible for forest resource evaluation in Illinois, Indiana, Iowa, Kansas, Michigan, Minnesota, Missouri, Nebraska, North Dakota, eastern South Dakota, and Wisconsin.

Fieldwork for the Wisconsin Statewide forest inventory was begun in the summer of 1981 and completed in late 1983. Reports on the three previous Forest Service inventories of Wisconsin's timber resource are dated 1936 , 1956 , and 1968 .

Similar Resource Bulletins reporting statistical highlights and detailed tables on the other Units in Wisconsin will soon be available. In addition to these statistical reports, a series of analytical reports will also be published.

More accurate survey information was obtained during the 1983 survey than otherwise would have been feasible because of intensified field sampling. Such sampling was made possible by additional funding and field personnel provided the North Central Station by the Wisconsin State Legislature through the Department of Natural Resources. Data from the Departments' canvass of all primary wood-using plants in the State was used to help estimate the quantity of timber products harvested in Wisconsin.

Aerial photos used in the Northwest Unit Forest Inventory were furnished by the Wiseonsin Department of Natural Resources, the USDA Agricultural Stabilization and Conservation Service, and the Chequamegon National Forest. 


\section{CONTENTS}

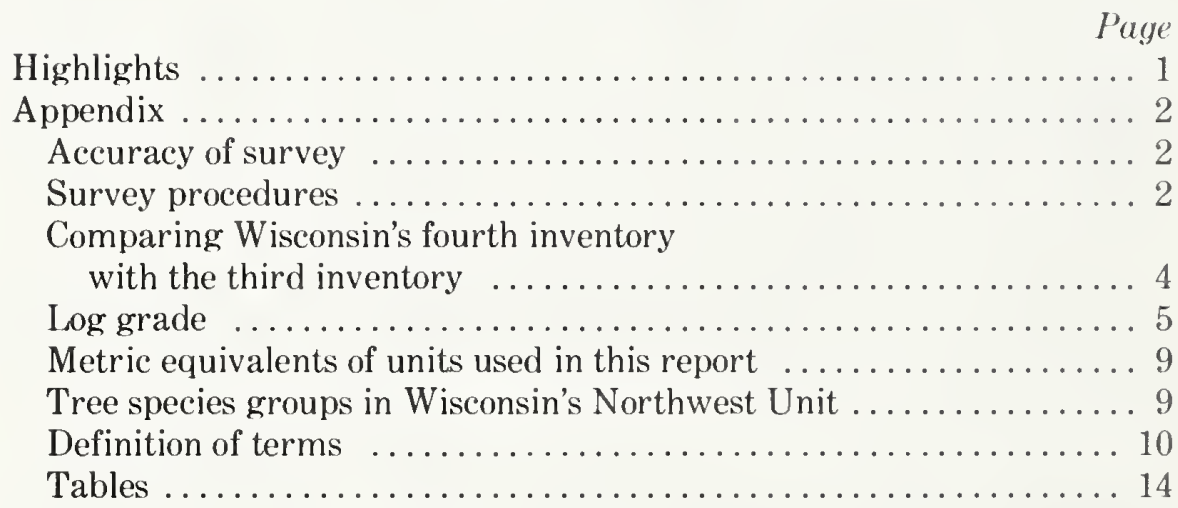




\title{
TIMBER RESOURCE OF WISCONSIN'S NORTHWEST SURVEY UNIT, 1983
}

\author{
W. Brad Smith, Mensurationist
}

\section{HIGHLIGHTS}

\section{Forest Area}

- Forest land accounted for 5.4 million acres (67 percent of the Unit's land area) in 1983, this constitutes no change since 1968.

- Commercial forest land occupied 5.1 million acres in 1983, and 5.2 million acres in 1968-a decline of less than 2 percent.

- Productive-reserved forest land totaled 114,600 acres in 1983, compared to 5,500 acres in 1968 . Major additions since 1968 include the Apostle Islands National Lakeshore, St. Croix Wild and Scenic Riverway, Flambeau River Wilderness. area, and the Rainbow Lake Wilderness area.

- Bayfield County contained the largest area of commercial forest in $1983(740,500$ acres $)$ and in 1968 (777,300 acres).

- Farmers and miscellaneous private individuals continued to hold 2.3 million acres (45 percent of the commercial forest) in 1983. A new definition of farm ownership shifted much of what was previously farmer owned to the miscellaneous private category.

- County and municipal agencies owned 1.1 million acres of commercial forest in 1983 (21 percent).

- The aspen and maple-birch forest types continue to dominate the commercial forest land base in 1983 comprising 59 percent of the commercial forest area.

- Poletimber stands occupied 50 percent of the commercial forest in 1983 as compared to 54 percent in 1968.

- Sawtimber stands, which increased by 510,900 acres between surveys, amounted to 22 percent of the commercial forest in 1983, compared to 12 percent in 1968.

- Fifty-one percent of the commercial plantation area is in the red pine type $(97,900)$ acres and 38 percent is in the jack pine type (72,500 acres).

- Nineteen percent of all commercial forest area has balsam fir as a prominent conifer in the understory.
- Less than 4 percent of all forest land is unproductive or reserved.

- Stands aged 80 years or more increased from 7 percent of the commercial forest area in 1968 to 10 percent in 1983.

- The average site index for commercial forest land in the Unit is 64 feet.

\section{Timber Volume}

- The volume of growing stock volume in 1983 was 5.3 billion cubic feet, 33 percent greater than the 3.9 billion in 1968 .

- Sawtimber volume amounted to 10.1 billion board feet in 1983, 68 percent greater than the 1968 volume.

- The 4.0 billion cubic feet of hardwoods make up 75 percent of the growing-stock volume.

- White spruce growing-stock volume increased 363 percent since 1968 and red pine growing-stock volume increased 224 percent. Ingrow th of plantations to merchantable size was the dominant factor in these dramatic increases.

- The aspens (1.1 billion cubic feet), maples (1.0 billion), and oaks ( 0.5 billion) contain the highest volumes, and together account for nearly half of the growing-stock volume.

- Average growing-stock volume per acre in 1983 was 1,032 cubic feet, compared to 743 cubic feet in 1968.

- Forty-seven percent of the growing-stock volume is in stands aged 41 to 60 years.

- Nearly three-quarters of the sawtimber volume is in trees with grade 3 butt logs. Tree diameter is generally the limiting criteria.

- The volume in cull trees (rough, rotten, and short$\log$ cull) is 648 million cubic feet; salvable dead tree volume is 280 million cubic feet.

\section{Stand Conditions}

- Net annual growth on growing-stock trees was 179 million cubic feet in 1982. 
- The net annual growth rate of growing stock was 3.4 percent of inventory in 1982.

- Net growth averaged 33.7 cubic feet per acre in 1982.

- Annual mortality of growing stock amounted to 49 million cubic feet ( 0.9 percent of inventory) in 1982.

- Disease accounted for 18 percent of the mortality in 1982; chiefly diseases of aspen and elm.

\section{Timber Use}

- Timber removals from growing stock in 1981 totaled nearly 96 million cubic feet (1.8 percent of inventory), compared to 78 million cubic feet (1.9 percent of inventory) in 1967.

- The aspens made up 46 percent of the 1981 removals volume, although they account for only 22 percent of the growing-stock volume.

- Output of roundwood products totaled 110 million cubic feet in 1981; 62 percent was pulpwood, 17 percent was saw logs, and 17 percent was fuelwood.

- Wood residue from primary plants totaled 8.5 million cubic feet in 1981, 0.3 million of which were not used.

\section{Biomass}

- Highest yields of live tree biomass are in the white pine (85 green tons per acre) and the maple-birch (84 tons) forest types.

- Live tree biomass (trees greater than 1-inch in d.b.h.) totaled 332 million green tons (64 tons per acre) in 1983, nearly one half in the boles of growing-stock trees.

\section{APPENDIX}

\section{ACCURACY OF SURVEY}

Forest Inventory and Analysis information is based on a sampling procedure designed to provide reliable statistics at the State and Unit levels. Consequently, the reported figures are estimates only. A measure of reliability of these figures is given by sampling errors. These sampling errors mean that the chances are two out of three that if a 100 -percent inventory had been taken, using the same methods, the results would have been within the limits indicated.

For example, the estimated growing-stock volume in the Northwest Unit in 1983, 5,311.4 million cubic feet, has a sampling error of \pm 1.49 percent $( \pm 79.1$ million cubic feet). The growing-stock volume from a 100-percent inventory would be expected to fall between 5,232.3 and 5,390.5 million cubic feet (5,311.4 \pm 79.1), there being a one in three chance that this is not the case.

Sampling errors were calculated separately for national forest land and other land because of the difference in the way the inventories were conducted. For example, the sampling error for growing-stock volume on land other than national forest is \pm 1.56 percent but for Chequamegon National Forest land it is \pm 4.39 percent. Different survey intensities resulted in different sampling errors.

The following tabulation shows the sampling errors for the 1983 Northwest Unit Forest Inventory:

$\begin{array}{ccc}\begin{array}{c}\text { Item } \\ \text { Growing stock }\end{array} & \begin{array}{c}\text { Sampling } \\ \text { error }\end{array} \\ \text { Volume } & \text { (Million cubic feet) } & \begin{array}{c}\text { (Percent) } \\ \text { Growth }\end{array} \\ \text { Removals } & 5,311.4 & 1.49 \\ \text { Sawtimber } & 179.2 & 3.13 \\ \text { Volume } & 95.4 & 16.29 \\ \text { Removals } & \text { (Million board feet) } & \\ \text { Commercial forest } & 10,057.4 & 2.44 \\ \text { land } & 249.6 & 19.95 \\ & \text { (Thousand acres) } & \\ & 5,150.8 & 0.49\end{array}$

As survey data are broken down into sections smaller than Survey Unit totals, the sampling error increases. For example, the sampling error for growing-stock volume in a particular county is higher than that for total growing-stock volume in the Unit (table 66 shows the sampling errors for estimates smaller than Unit totals).

\section{SURVEY PROCEDURES}

We used a two-phase sampling design for the 1983 Wisconsin survey. This sampling scheme and associated estimators are similar to sampling with partial replacement (SPR) in that a set of randomly located plots was available for remeasurement and a set of new randomly located plots were established and measured. Major enhancements in the new Wisconsin design were stratification for disturbance on the old

\footnotetext{
${ }^{1}$ International $1 / 4$-inch mule.
} 
sample and use of a growth model to improve regression estimates made on the old undisturbed forest plots. The growth model used was the Stand and Tree Evaluation and Modeling System (STEMS).

The major steps in the new survey design were as follows:

1. The first phase of the design was aerial photo interpretation. In this phase two sets of random points were located on current aerial photographs. The first was a set of new photo points and the second was a set of relocated old photo points (ground plot locations from the previous inventory). A total of 42,566 1-acre points, including old ground sample locations, were systematically distributed across aerial photos of the entire Unit, except the Chequamegon National Forest. These points were classified into land classes as shown below to make a preliminary estimate of forest area. Next, a total of 30,121 of these points were stereoclassified as to stand-size class and density. Finally, a total of 3,973 points were examined on the ground to correct the preliminary area estimate for errors in classification and for actual changes in land use since the photos were taken.

\section{Photo points}

$\begin{array}{lrrr}\begin{array}{l}\text { Land class } \\ \text { Forest land }\end{array} & \begin{array}{c}\text { Classified } \\ \text { Stereoclassified }\end{array} & \begin{array}{c}\text { plots } \\ \text { checked }\end{array} \\ \begin{array}{l}\text { Unproductive/ } \\ \text { reserved } \\ \text { forest land }\end{array} & 652 & 28,710 & 2,583 \\ \begin{array}{l}\text { Nonforest land } \\ \text { with trees } \\ \text { without trees }\end{array} & 10,775 & 652 & 76 \\ \text { water } & \frac{7,670}{2} & -159 & 55 \\ \text { Total } & 42,566 & 30,121 & 1,118 \\ \end{array}$

2. The second phase of the design is a ground sample. The plot selection and measurement procedures of phase two of the new Wisconsin survey design are outlined in figure 1.

From the new photo points, a random sample of ground plots were established and measures of land use, volume, mortality and cutting were recorded. At each forest ground plot location, variable-radius plots (basal area factor 37.5) were established at 10 points

\footnotetext{
${ }^{2}$ For more information on STEMS, see: Belcher, D. L.; Holdaway, M. R.; Brand, G. J. A description of STEMS: The stand and tree evaluation and modeling system. Gen. Tech. Rep. NC-79. St. Paul, MN: U.S. Department of Agriculture, Forest Service, North Central Fortst Experiment Station; 1981. 18 p.
}

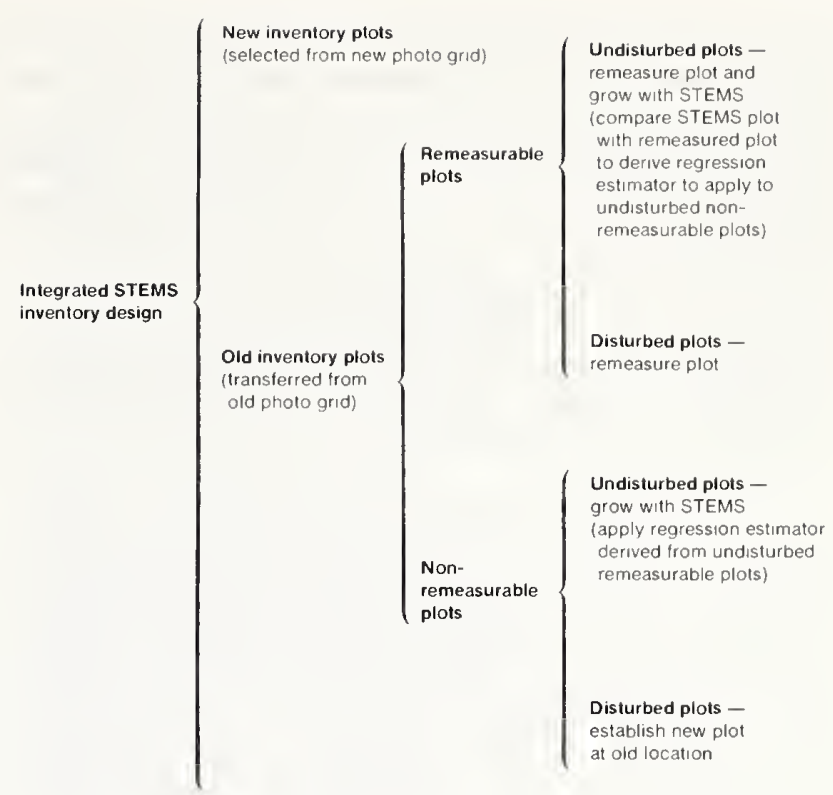

Figure 1.-Logic structure for the 1983 Wisconsin sample design.

uniformly placed over the sample acre. These locations were monumented for future remeasurement.

On the old inventory photo points (old plot locations) we used a somewhat different procedure. Old plots were either remeasurable (monumented) or nonremeasurable (not monumented and thus difficult to relocate in the field). Within both of these groups, old plots were additionally identified as undisturbed or disturbed. The remeasurable old inventory photo points which are classified as forest undisturbed were remeasured on the ground to obtain measurements of current land use, volume, growth and removals. Additionally, all forest undisturbed remeasurable plots were projected to the current time using STEMS, to provide estimates of current volume and growth. The comparison of the projected and observed values on these plots provided regression estimators to adjust the projected values of the undisturbed nonremeasurable plots. All disturbed remeasurable plots were remeasured on the ground to assess changes since the last inventory. Disturbance as used here refers to any change on a plot that can be detected on aerial photos and which the STEMS growth processor cannot predict, such as; catastrophic mortality, cutting, seedling stands, and land use change.

The nonremeasurable forest points are those that were not monumented during the 1968 inventory but played a crucial role in the new survey design. The nonremeasurable undisturbed forest points were visited on the ground at the time of the last survey and following careful examination of both past and current photographs it was determined that nothing happened that STEMS was unable to simulate. STEMS was 
then used to update the old plot and tree data to produce an estimate of current data. Thus these points became ground plots even though the information was obtained without actually visiting the plot. The plot record for each updated plot was sent to the field for verification of current ownership information. For points classified as disturbed, a new ground plot was established as close to the old location as possible. This allowed information about land use trends to be recorded even though the old plot could not be exactly relocated for remeasurement.

The estimation procedure for computing statistics from this sampling design was more complicated than the simple two-phase estimation procedure used in the past. In fact, this procedure yielded two independent samples, one coming from the new photo points and the other from the old photo points that were remeasured or projected. A more detailed description of the sampling design is available in a separate publication. ${ }^{3}$

3. Under an agreement with the Forest Service's Eastern Region 9, North Central crews remeasured 10 -point variable radius plots on the Chequamegon National Forest at the same time they remeasured other plots in the Northwest Unit. The Chequamegon National Forest provided the Station with area of commercial forest land by forest type, stand-size class, and density for the forest. The Station then computed volume, growth, and mortality statistics. Area and volume tables for the forest were approved by the Chequamegon National Forest staff before publication.

4. Statistics on timber utilization during 1981 were obtained from mill surveys. The Wisconsin Department of Natural Resources canvassed resident sawmills, veneer mills, and other primary wood-using plants. The North Central Forest Experiment Station canvassed out-of-State sawmills, pulpmills, and veneer mills to determine their use of Wisconsin timber. Fuelwood and fence post output was based on a sample of public and private landowners to determine their production of fuelwood and fenceposts. Estimates of primary mill residue used for fuelwood were obtained from the canvass of Wisconsin primary wood-using plants. Timber cut for products by ownership class was determined by a canvass of public and industrial timber owners. The portion of timber cut unaccounted for by these owners was listed under "farmer and other owners".

${ }^{3}$ For more information see: Hahn, J. T.; Hansen, $M$. H.; Fairweather, S. E. A sampling procedure incorporating a growth simulator. St. Paul, MN: U.S. Department of Agriculture, Forest Service, North Central Forest Experiment Station; 1984. (In prep.)
5. A total of 2,568 felled trees on 133 active logging operations were measured throughout the State during 1981-1982 to develop wood utilization factors for converting timber products output to timber removals for saw logs and pulpwood. Factors for all other products were obtained during the 1966-1967 Wisconsin utilization study.

6. Field data were sent to St. Paul, Minnesota, for processing and analysis.

\section{COMPARING WISCONSIN'S FOURTH INVENTORY WITH THE THIRD INVENTORY}

Data from new forest inventories are often compared with data from earlier inventories to determine trends in forest resources. However, changes in procedures and definitions between surveys often make it necessary to adjust earlier survey data so that they are comparable to data from the new survey. A consistency check will be made for each forest unit in Wisconsin to ensure that the changes observed between inventories reflect actual changes in the resource and not changes in definitions or procedures.

\section{Identifying and Correcting Procedural Changes}

Some procedural changes were made between the 1968 and 1983 inventories of northwest Wisconsin in the method of deriving annual mortality estimates and determining forest type.

Mortality figures for the 1968 inventory were based on field estimates from nonremeasurement plots. Information gathered on remeasurement plots during the current inventory was used to adjust the 1968 mortality figures. This adjustment also changed the estimate of net growth for the 1968 inventory. Additionally, the old spruce-fir forest type was separated into two distinct types for the new inventory - white spruce and balsam fir. Comparisons with old data may be made by adding the two new types together.

Except for the net growth and mortality information, the old and new inventories of this region may be directly compared.

\section{Checking for Consistency}

A test was made to ensure that it was possible to move from the adjusted 1968 resource statistics to the 1983 values by means of Timber Resource Analysis System (TRAS), a USDA Forest Service computer program for updating, backdating, and projecting 
timber volume, growth, mortality, and removals. Using the adjusted 1968 numbers of softwood and hardwood trees by 2 -inch diameter class and applying 1983 cubic feet per tree estimates, volumes were generated for the 1968 inventory that are comparable with 1983 volumes. Then, using growth rates, mortality rates, and removals rates for the period between the two surveys, TRAS projected the inventory from 1968 to 1983 . The program prints out volumes by diameter class for softwoods and hardwoods for selected years in the period. Thus, inconsistencies in volume, growth, mortality, and removals were identified and resolved.

TRAS generates an estimate of what total removals had to be in order for the inventory to have changed as it did between surveys, given the volume, growth, and mortality inputs. Estimates of removals for products and for logging residues, two of the three components of total timber removals, were available from an independent utilization study. An estimate of "other" removals (see Definition of Terms in Appendix), the third component of total removals, was made by subtracting the first two removals components from the TRAS-generated total removals estimate. This estimate of "other" removals was compared with findings from remeasurement plots and new plots (stump counts and land use change) to check its validity.
When necessary, TRAS was rerun and adjusted until other removals were compatible with the estimate from field data. Total removals were "trend level removals" because the estimate of "other" removals was based on a removals trend line from 1968 to 1983.

\section{LOG GRADE}

In Wisconsin's Northwest Unit the butt log of every sawtimber tree on every full permanent sample plot was graded for quality.

Butt logs were graded on the basis of external characteristics as indicators of quality. Hardwood species were graded according to Hardwood Log Grades for Standard Lumber. ${ }^{4}$ The best 12-foot section of the lowest 16 -foot hardwood log, or the best 12-foot upper section if the butt log did not meet minimum log-grade standards, was graded as follows:

${ }^{4}$ Vaughn, C. L.; Wollin, C. A.; McDonald, K. A.; Bulgrin, E. H. Hardwood log grades for standard lumber. Res. Pap. FPL-63. Madison, WI: U.S. Department of Agriculture, Forest Service, Forest Products Laboratory; $1966.52 \mathrm{p}$. 


\section{Forest Service standard grades for hardwood factory saw logs}

\begin{tabular}{|c|c|c|c|c|c|c|c|c|c|}
\hline \multirow{2}{*}{\multicolumn{2}{|c|}{ Grading factors }} & \multicolumn{8}{|c|}{ Specifications } \\
\hline & & \multicolumn{3}{|c|}{ Log grade 1} & \multicolumn{4}{|c|}{ Log grade 2} & \multirow{2}{*}{$\begin{array}{c}\text { Log grade } 3 \\
\begin{array}{c}\text { Butts and } \\
\text { uppers }\end{array}\end{array}$} \\
\hline \multicolumn{2}{|l|}{ Position in tree } & $\begin{array}{c}\text { Butts } \\
\text { only }\end{array}$ & \multicolumn{2}{|c|}{$\begin{array}{l}\text { Butts and } \\
\text { uppers }\end{array}$} & \multicolumn{4}{|c|}{ Butts and uppers } & \\
\hline \multicolumn{2}{|c|}{ Scaling diameter, inches } & $13-15^{1}$ & $16-19$ & $20+$ & $11+2$ & & $12+$ & & $8+$ \\
\hline \multicolumn{2}{|c|}{ Length without trim, feet } & & $10+$ & & $10+$ & $8-9$ & $10-11$ & $12+$ & $8+$ \\
\hline \multirow{3}{*}{$\begin{array}{l}\text { Required clear } \\
\text { cuttings }^{3} \text { of each of } \\
\text { three best faces }\end{array}$} & Min. length, feet & 7 & 5 & 3 & 3 & 3 & 3 & 3 & 2 \\
\hline & Max. number & 2 & 2 & 2 & 2 & 2 & 2 & 3 & $\begin{array}{l}\text { No } \\
\text { Limit }\end{array}$ \\
\hline & $\begin{array}{l}\text { Min. proportion of } \\
\text { log length } \\
\text { required in } \\
\text { clear cutting }\end{array}$ & $5 / 6$ & $5 / 6$ & $5 / 6$ & $2 / 3$ & $3 / 4$ & $2 / 3$ & $2 / 3$ & $1 / 2$ \\
\hline \multirow{2}{*}{$\begin{array}{l}\text { Maximum } \\
\text { sweep and crook } \\
\text { allowance }\end{array}$} & $\begin{array}{l}\text { For logs with less } \\
\text { than one-fourth } \\
\text { of end in sound } \\
\text { defects }\end{array}$ & \multicolumn{3}{|c|}{15 percent } & \multicolumn{4}{|c|}{30 percent } & 35 percent \\
\hline & $\begin{array}{l}\text { For logs with more } \\
\text { than one-fourth } \\
\text { of end in sound } \\
\text { defects }\end{array}$ & \multicolumn{3}{|c|}{15 percent } & \multicolumn{4}{|c|}{20 percent } & 35 percent \\
\hline \multicolumn{2}{|c|}{ Maximum scaling deduction } & \multicolumn{3}{|c|}{40 percent $^{5}$} & \multicolumn{4}{|c|}{50 percent $^{6}$} & 50 percent \\
\hline
\end{tabular}

'Ash and basswood butts can be 12 inches if they otherwise meet requirements for small \#1's.

${ }^{2}$ Ten-inch logs of all species can be \#2 if they otherwise meet requirements for small \#1's.

${ }^{3} \mathrm{~A}$ clear cutting is a portion of a face, extending the width of the face, that is free of defects.

${ }^{4} \mathrm{~A}$ face is one-fourth of the surface of the log as divided lengthwise.

${ }^{5}$ Otherwise \#1 logs with 41-60 percent deductions can be \#2.

${ }^{6}$ Otherwise \#2 $\log$ s with 51-60 percent deductions can be \#3. 


\section{Forest Service standard specifications for hardwood construction logs (tie and timber logs) ${ }^{1}$}

\begin{tabular}{|c|c|c|}
\hline \multicolumn{2}{|l|}{ Position in tree } & Butt and upper \\
\hline \multicolumn{2}{|l|}{ Min. diameter, small end } & 8 inches + \\
\hline \multicolumn{2}{|l|}{ Min. length, without trim } & 8 feet \\
\hline \multicolumn{2}{|l|}{ Clear cuttings } & No requirements. \\
\hline \multicolumn{2}{|l|}{ Sweep allowance, absolute } & One-fourth of the diameter at the small end for each 8 feet of length. \\
\hline \multirow{3}{*}{$\begin{array}{l}\text { Sound } \\
\text { surface } \\
\text { defects }\end{array}$} & Single knots & $\begin{array}{l}\text { Any number, if no one knot has an average age diameter above the callus in } \\
\text { excess of one-third of log diameter at point of occurrence. }\end{array}$ \\
\hline & Whorled knots & $\begin{array}{l}\text { Any number if sum of knot diameters above the callus does not exceed one- } \\
\text { third of log diameters at point of occurrence. }\end{array}$ \\
\hline & Holes & $\begin{array}{l}\text { Any number provided none has a diameter over one-third of log diameter at } \\
\text { point of occurrence, and none extends over } 3 \text { inches into included timber. }\end{array}$ \\
\hline \multicolumn{2}{|l|}{ Unsound surface defects } & $\begin{array}{l}\text { Same requirements as for sound defects if they extend into included time. }{ }^{2} \text { No } \\
\text { limit if they do not. }\end{array}$ \\
\hline & Sound & No requirements. \\
\hline $\begin{array}{l}\text { End } \\
\text { defects }\end{array}$ & Unsound & $\begin{array}{l}\text { None allowed; log must be sound internally, but will admit one shake not to } \\
\text { exceed one-fourth of the scaling diameter will admit a longitudinal split not } \\
\text { extending over } 5 \text { inches into the contained timber. }\end{array}$ \\
\hline
\end{tabular}

${ }^{1}$ These specifications are minimum for the class. If, from a group of logs, factory logs are selected first, thus leaving only nonfactory logs from which to select construction logs, then the quality range of the construction logs so selected is limited, and the class may be considered a grade. If selection for construction logs is given first priority, then it may be necessary to subdivide the class into grades.

${ }^{2}$ Included timber is always square, and dimension is judged from small end.

Softwood species were graded according to the following specifications: 


\section{Log Grades for Eastern White Pine}

\begin{tabular}{|c|c|c|c|c|c|c|}
\hline $\begin{array}{l}\text { Log } \\
\text { grade }\end{array}$ & $\begin{array}{l}\text { Minimu } \\
\text { Diameter }\end{array}$ & $\begin{array}{l}n \text { size } \\
\text { Length }\end{array}$ & $\begin{array}{l}\text { Sweep } \\
\text { or crook } \\
\text { allowance }\end{array}$ & $\begin{array}{l}\text { Total cull } \\
\text { allowance } \\
\text { including } \\
\text { sweep }\end{array}$ & $\begin{array}{l}\text { Maximum } \\
\text { weevil } \\
\text { injury }\end{array}$ & $\begin{array}{l}\text { Allowable knot size (inches) }{ }^{2} \text { on three best faces or } \\
\text { minimum clearness of four faces }\end{array}$ \\
\hline \multirow{3}{*}{1} & Inches & Feet & \multicolumn{2}{|c|}{-------Percent------- } & Number & $\begin{array}{r}\text { Inches } \\
\text {. }\end{array}$ \\
\hline & $12 \& 13$ & $8-16$ & 20 & 50 & 0 & Four faces clear full length \\
\hline & $14+$ & $10-16$ & 20 & 50 & 0 & $\begin{array}{l}\text { Two faces clear full length, or four faces clear } 50 \text { percent } \\
\text { length ( } 6 \text { feet min. length })^{3}\end{array}$ \\
\hline 2 & $6+$ & $8-16$ & 30 & 50 & 0 & $\begin{array}{l}\text { Sound knots I.e. }{ }^{4} D / 6 \text { and less than } 3 \text { inches }{ }^{5} \\
\text { Unsound knots: I.e. } 11 / 2 \text { inches and for: butt, lots I.e. } D / \\
12 \text { upper logs I.e. } D / 10 \text { or four faces clear } 50 \text { percent of } \\
\text { length }\end{array}$ \\
\hline 3 & $6+$ & $8-16$ & 40 & 50 & $\begin{array}{c}\text { 8-foot logs } \\
1 \text { weevil } \\
\text { 10-foot + logs: } \\
2 \text { weevil }\end{array}$ & $\begin{array}{l}\text { Sound knots I.e. D/3 and less than } 5 \text { inches. } \\
\text { Unsound knots I.e.D/6 and less than } \\
21 \frac{1}{2} \text { inches. }\end{array}$ \\
\hline 4 & $6+$ & $8-16$ & 50 & 50 & No limit & No limit \\
\hline
\end{tabular}

${ }^{1}$ Plus trim.

${ }^{2}$ Disregard all knots less than $1 / 2$-inch diameter in all grades.

${ }^{3}$ The sum of the diameter of sound knots plus twice the sum of the diameter of unsound knots (in inches) is less than or equal to $1 / 2$ of the diameter of the log (inches).

4.e. means less than or equal to.

${ }^{5} \mathrm{D}$ means d.i.b. of log at location of knot.

\section{LOG GRADES FOR JACK PINE AND RED PINE}

Grade 1: $\log$ s with three or four clear faces. ${ }^{5}$

Grade 2: logs with one or two clear faces.

Grade 3: logs with no clear faces.

After the tentative log grade is established, the log will be degraded one grade for each of the following, except that no log can be degraded below grade 3 . Net scale after deduction for defect must be at least 50 percent of the gross contents of the log.

1. Sweep. Degrade any tentative 1 or $2 \log$ one grade if sweep amounts to 3 or more inches and equals

${ }^{5} A$ face is one-fourth of the circumference in width extending full length of the log. Clear faces are those free of: knots measuring more than $1 / 2$-inch in diameter, overgrown knots of any size, holes more than 1/4-inch in diameter. Faces may be rotated to obtain the maximum number of clear ones. or exceeds one-third the diameter inside bark at small end.

2. Heart rot. Degrade any tentative 1 or 2 log grade if conk, massed hyphae, or other evidence of advance heart rot is found anywhere in it.

\section{LOG GRADES FOR ALL OTHER SOFTWOOD LOGS}

\section{Grade 1}

1. Logs must be 16 inches in diameter or larger, 10 feet or longer, and with deduction for defect not over 30 percent of gross scale.

2. Logs must be at least 75 percent clear on each of three faces.

3. All knots outside clear cutting must be sound and not over $2-1 / 2$ inches in size.

\section{Grade 2}

1. Logs must be 12 inches in diameter or larger, 10 feet or longer, and with a net scale after deduction 
for defect of at least 50 percent of the gross contents of the log.

2. Logs must be at least 50 percent clear on each of three faces or 75 percent clear on two faces.

\section{Grade 3}

1. Logs must be 6 inches in diameter or larger, 8 feet or longer, and with a net scale after deduction for defect of at least 50 percent of the gross contents of the log.

Note: (A) Diameters are diameter inside bark (d.i.b.) at small end of log.

(B) Percent clear refers to percent clear in one continuous section.

\section{METRIC EQUIVALENTS OF UNITS USED IN THIS REPORT}

1 acre $=4,046.86$ square meters or 0.405 hectare .

1,000 acres $=405$ hectares.

1 cubic foot $=0.0283$ cubic meter.

1 foot $=30.48$ centimeters or 0.3048 meter.

1 inch $=25.4$ millimeters, 2.54 centimeters, or 0.0254 meter.

1 pound $=0.454$ kilogram.

1 ton $=0.907$ metric ton.

\section{TREE SPECIES GROUPS IN WISCONSIN'S NORTHWEST UNIT'6}

\section{SOFTWOODS}

Jack pine ............... Pinus banksiana

Red pine ................. Pinus resinosa

Eastern white pine ............ Pinus strobus

White spruce ............... Picea glauca

Black spruce ............... Picea mariana

Balsam fir .................... Abies balsamea

Eastern hemlock ...........Tsuga canadensis

Tamarack ................ Larix laricina

Northern white-cedar ...... Thuja occidentalis

Other softwoods

Eastern redcedar ...... Juniperus virginiana

Norway spruce ...............Picea abies

Scotch pine ............. Pinus sylvestris

${ }^{6}$ The common and scientific names are based on: Little, Elbert L. Check list of native and naturalized trees of the United States. Agric. Handb. 541. Washington, DC: U.S. Department of Agriculture, Forest Service; 1979. 375 p.
HARDWOODS

White oaks

White oak Quercus alba

Swamp white oak ......... Quercus bicolor

Bur oak ............ Quercus macrocarpa

Chinkapin Oak ....... Quercus muehlenbergii

Select red oak

Northern red oak .......... Quercus rubra

Other red oaks

Northern pin oak .......Quercus ellipsoidalis

Black oak ............. Quercus velutina

Select hickory

Shagbark hickory ........... Carya ovata

Other hickory

Bitternut hickory ......... Carya cordiformis

Yellow birch .......... Betula alleghaniensis

Hard maple

Sugar maple ..............Acer saccharum

Black maple ............... Acer nigrum

Soft maples

Red maple .................Acer rubrum

Silver maple ............ Acer saccharinum

Ashes

White ash ...........Fraxinus americana Black ash ............. Fraxinus nigra Green ash ..........Fraxinus pennsylvanica

Balsam poplar ........... Populus balsamifera

Eastern cottonwood .........Populus deltoides

Sycamore ............ Platanus occidentalis Aspens

Bigtooth aspen ....... Populus grandidentata

Quaking aspen ......... Populus tremuloides

American basswood ...........Tilia americana

Beech ................. Fagus grandifolia

Black walnut ............. Juglans nigra

Black cherry ............. Prunus serotina

Butternut .............. Juglans cinerea

Elms

American elm .......... Ulmus americana

Slippery elm ............... Ulmus rubra

Rock elm .............. Ulmus thomasii

Hackberry ............. Celtis occidentalis

Paper birch ............ Betula papyrifera

Black willow ............... Salix nigra

Other hardwoods

Boxelder ..................Acer negundo

Black locust .......... Robinia pseudoacacia

Honeylocust ......... Gladitsia triacanthos

River birch .............. Betula nigra

Red mulberry .............. Morus rubra

Blackgum ............... Nyssa silvatica

Northern Catalpa ........ Catalpa speciosa

Noncommercial species

Mountain maple .............Acer spicatum

Eastern hophornbeam .... Ostrya virginiana

Peachleaf willow ........ Salix amygdaloides 
American hornbeam .... Carpinus caroliniana Hawthorn ............... Crataegus spp. Striped maple ..........Acer pensylvanicum

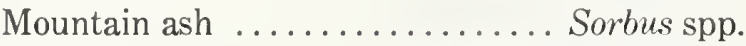
Pin cherry ............Prunus pensylvanica Chokecherry ............Prunus virginiana

\section{DEFINITION OF TERMS}

Acceptable trees.-Growing-stock trees of commercial species that meet specified standards of size and quality but do not qualify as desirable trees.

Basal area.-The area in square feet of the cross section at breast height of a single tree. When the basal area of all trees in a stand are summed, the result is usually expressed as square feet of basal area per acre.

Biomass. - The above-ground volume of all live trees (including bark and foliage) reported in green tons. Biomass is made up of 5 components:

Growing-stock bole.-Biomass of a growing-stock tree from a 1-foot stump to a variable 4-inch top.

Growing-stock tops and limbs.-Biomass of a growing-stock tree from a 1-foot stump minus the growing-stock bole.

Cull bole.-Biomass of a cull tree from a 1-foot stump to a variable 4 -inch top.

Cull tops and limbs.-Biomass of a cull tree from a 1-foot stump minus the cull bole.

1-to 5-inch trees. - Biomass of all live trees 1 - to 5 -inches in diameter at breast height.

Commercial forest land.-Forest land producing or capable of producingerops of industrial wood and not withdrawn from timber utilization. (Note: Areas qualifying as commercial forest land are capable of producing more than 20 cubic feet per acre per year of annual growth under management. Currently inaccessible and inoperable areas are included, except when the areas involved are small and unlikely to become suitable for producing of industrial wood in the foreseeable future.) Also see definition of pastured commercial forest land.

Commercial species.-Tree species presently or prospectively suitable for industrial wood products. (Note: Excludes species of typically small size, poor form, or inferior quality such as hophornbeam and hawthorn.)

County and municipal land.-Land owned by counties and local public agencies or municipalities, or land leased to these governmental units for 50 years or more.

Cull.-Portions of a tree that are unusable for industrial wood products, because of rot, form, or other defect.
Desirable trees.-Growing-stock trees having no serious defects in quality limiting present or prospective use, having relatively high vigor, and containing no pathogens that may kill or seriously deteriorate them before rotation age. These trees would be favored by forest managers in silvicultural operations.

Diameter classes. - A classification of trees based on diameter outside bark, measured at breast height ( $4-1 / 2$ feet above the ground). (Note: d.b.h. is the common abbreviation for diameter at breast height. Two-inch diameter classes are commonly used in Forest Survey, with the even inch the approximate midpoint for a class. For example, the 6-inch class includes trees 5.0 through 6.9 inches d.b.h.)

Farm.-Either a place operated as a unit of 10 or more acres from which the sale of agricultural products totals $\$ 50$ or more annually, or a place operated as a unit of less than 10 acres from which the sale of agricultural products for a year amounts to at least $\$ 250$. Places having less than the $\$ 50$ or $\$ 250$ minimum estimated sales in a given year are also counted as farms if they can normally be expected to produce goods in sufficient quantity to meet the requirements of the definition.

Farmer-owned land.-Land owned by farm operators. (Note: Excludes land leased by farm operators from nonfarm owners, such as railroad companies and States.)

Forest land.-Land at least 16.7 percent stocked by forest trees of any size, or formerly having had such tree cover, and not currentlydeveloped for nonforestuse. (Note: Stocking is measured by comparison of basal area and/ornumber of trees, by age or size and spacing with specified standards.) The minimum area for classification of forest land is 1 acre. Roadside, streamside, and shelterbelt strips of timber must have a crown width of at least 120 feet to qualify as forest land. Unimproved roads and trails, streams, or other bodies of water or clearings in forest areas shall be classed as forest if less than 120 feet wide. Also see definitions for land area, commercial forest land, noncommercial forest land, productive-reserved forest land, stocking, unproductive forest land, and water.

Forest industry land.-Land owned by companies or individuals operating primary wood-using plants.

Forest trees.-Woody plants having a well-developed stem and usually more than 12 feet tall at maturity. 
Forest type.-A classification of forest land based on the species forming a plurality of live tree stocking. Major forest types in the State are:

Jack pine.-Forests in which jack pine comprises a plurality of the stocking. (Common associates include eastern white pine, red pine, aspen, birch, and oak.)

Red pine.-Forests in which red pine comprises a plurality of the stocking. (Common associates include eastern white pine, jack pine, aspen, birch, and oak.)

White pine.-Forests in which eastern white pine comprises a plurality of the stocking. (Common associates include red pine, aspen, birch, and maple.)

Balsam fir. -Forests in which balsam fir and white spruce comprise a plurality of stocking with balsam fir the most common. (Common associates include white spruce, aspen, maple, birch, northern white-cedar, and spruce.)

White spruce.-Forests in which white spruce and balsam fir comprise a plurality of the stocking with white spruce the most common. (Common associates include balsam fir, aspen, maple, birch, and northern white-cedar.)

Black spruce.-Forests in which swamp conifers comprise a plurality of the stocking with black spruce the most common. (Common associates include tamarack, northern whitecedar, and balsam fir.)

Northern white-cedar.-Forests in which swamp conifers comprise a plurality of the stocking with northern white-cedar the most common. (Common associates include spruce and balsam fir.)

Tamarack.-Forests in which swamp conifers comprise a plurality of the stocking with tamarack the most common. (Common associates include black spruce, balsam fir, and aspen.)

Oak-hickory.-Forests in which northern red oak, white oak, bur oak, or hickories, singly or in combination, comprise a plurality of the stocking. (Common associates include jack pine, aspen, birch, and maple.)

Elm-ash-soft maple.-Forests in which lowland elm, ash, cottonwood, and red maple, singly or in combination, comprise a plurality of the stocking. (Common associates include aspen, birch, and balsam fir.)

Maple-birch.-Forests in which sugar maple, basswood, yellow birch, elm, and red maple, singly or in combination, comprise a plurality of the stocking. (Common associates include white pine, elm, hemlock, and basswood.)
Aspen.-Forests in which quaking aspen or bigtooth aspen, singly or in combination, comprise a plurality of the stocking. (Common associates include oak, pine, balsam fir, and paper birch.)

Paper birch.-Forests in which paper birch comprises a plurality of the stocking. (Common associates include maple, aspen, and balsam fir.)

Exotic.-Forests in which species not native to the State comprise a plurality of the stocking. (Mostly Scotch pine plantations.)

Gross area.-The entire area of land and water as determined by the Bureau of the Census, 1970.

Growing-stock trees.-Live trees of commercial species qualifying as desirable and acceptable trees. (Note: Excludes rough, rotten, and dead trees.)

Growing-stock volume.-Net volume in cubic feet of growing-stock trees 5.0 inches d.b.h. and over, from a 1-foot stump to a minimum 4.0 inch top diameter outside bark of the central stem or to the point where the central stem breaks into limbs. Cubic feet can be converted to standard cords by dividing by 79 cubic feet per solid wood cord. One standard cord is 128 cubic feet of stacked wood, including air and bark.

Hardwoods.-Dicotyledonous trees, usually broadleaved and deciduous.

Idle farmland.-Includes former cropland, orchards, improved pastures, and farm sites not tended within the past 2 years and presently less than 16.7 percent stocked with trees.

Improved pasture.-Land currently improved for grazing by cultivating, seeding, irrigating, or clearing of trees or brush and less than 16.7 percent stocked with live trees.

Indian land.-Tribal land held in fee but administered by the Federal Government.

Land area.-A. Bureau of the Census. The area of dry land and land temporarily or partly covered by water such as marshes, swamps, and river flood plains (omitting tidal flats below mean high tide); streams, sloughs, estuaries, and canals less than one-eighth of a statute mile wide; and lakes, reservoirs, and ponds less than 40 acres in area.

B. Forest Inventory and Analysis. The same as the Bureau of the Census, except minimum width of streams, etc., is 120 feet and minimum size of lakes, etc., is 1 acre.

Live trees.-Growing-stock, rough, and rotten trees 1 inch d.b.h. and larger.

Log grades. - A classification of logs based on external characteristics as indicators of quality or value. (See Appendix for specific grading factors used.)

Logging residues.-The unused growing stock portions of trees cut or killed by logging. 
Maintained road.-Any road, hard-topped or other surfaces, that is plowed or graded at least once a year. Includes rights-of-way that are cut or treated to limit herbaceous growth.

Marsh.-Nonforest land that characteristically supports low, generally herbaceous or shrubby vegetation and that is intermittently covered with water.

Merchantable.-Refers to a pulpwood or saw log section that meets pulpwood or saw log specifications, respectively.

Miscellaneous federal land.-Federal land other than National Forest, land administered by the Bureau of Land Management, and Indian land.

Miscellaneous private land.-Privately owned land other than forest-industry and farmer-owned land.

Mortality.-The volume of sound wood in growingstock and sawtimber trees that die annually.

National Forest land.-Federal land that has been legally designated as National Forest or purchase units, and other land administered by the USDA Forest Service.

Net annual growth of growing-stock.-The annual change in volume of sound wood in live sawtimber and poletimber trees and the total volume of trees entering these classes through ingrowth, less volume losses resulting from natural causes.

Net annual growth of sawtimber.-The annual change in the volume of live sawtimber trees and the total volume of trees reaching sawtimber size, less volume losses resulting from natural causes.

Net volume.-Gross volume less deductions for rot, sweep, or other defect affecting use for timber products.

Noncommercial forest land.-(a) Unproductive forest land and (b) productive-reserved forest land.

Noncommercial species.-Tree species of typically small size, poor form, or inferior quality that normally do not develop into trees suitable for industrial wood products.

Nonforest land.-Land that has never supported forests, and land formerly forested where use for timber management is precluded by development for other uses. (Note: Includes areas used for crops, improved pasture, residential areas, city parks, improved roads of any width and adjoining clearings, powerline clearings of any width, and 1- to 40-acre areas of water classified by the Bureau of the Census as land. If intermingled in forest areas, unimproved roads and nonforest strips must be more than 120 feet wide and more than 1 acre in area to qualify as nonforest land.)

a. Nonforest land without trees.-Nonforest land with no live trees present.

b. Nonforest land with trees.-Nonforest land with one or more trees per acre at least 5 inches d.b.h.
Nonstocked land.-Commercial forest land less than 16.7 percent stocked with growing-stock trees.

Other removals.-Growing-stock trees removed but not utilized for products, or trees left standing but "removed" from the commercial forest land classification by land use change. Examples are removals from cultural operations such as timber stand improvement work, land clearing, and changes in land use.

Ownership.-Property owned by one owner, regardless of the number of parcels in a specified area.

Ownership size class.-The amount of commercial forest land owned by one owner, regardless of the number of parcels.

Owner tenure.-The length of time a property has been held by the owner.

Physiographic class.-A measure of soil and water conditions that affect tree growth on a site. The physiographic classes are:

Xeric sites.-Very dry soils where excessive drainage seriously limits both growth and species occurrence. Example: sandy jack pine plains.

Xeromesic sites.-Moderately dry soils where excessive drainage limits growth and species occurrence to some extent. Example: dry oak ridge.

Mesic sites.-Deep, well-drained soils. Growth and species occurrence are limited only by climate.

Hydromesic sites.-Moderately wet soils where insufficient drainage or infrequent flooding limits growth and species occurrence to some extent. Example: better drained bottomland hardwood sites.

Hydric sites. - Very wet sites where excess water seriously limits both growth and species occurrence. Example: frequently flooded river bottoms and spruce bogs.

Plant byproducts.-Plant residues used for products such as mulch, pulp chips, and fuelwood.

Plant residues. - Wood and bark materials generated at manufacturing plants during production of other products.

Poletimber stands.-(See stand-size class.)

Poletimber trees.-Growing-stock trees of commercial species at least 5.0 inches d.b.h. but smaller than sawtimber size.

Productive-reserved forest land.-Forest land sufficiently productive to qualify as commercial forest land but withdrawn from timber utilization through statute, administration regulation, designation, or exclusive use for Christmas tree production, as indicated by annual shearing.

Productive-deferred.-Forest land sufficiently productive to qualify as commercial forest land but presently withdrawn from timber utilization because it is being considered for possible inclusion into the Wilderness system. 
Rotten trees.-Live trees of commercial species that do not contain at least one 12-foot saw log or two saw logs 8 feet or longer, now or prospectively, and/or do not meet regional specifications for freedom from defect primarily because of rot; that is, when more than 50 percent of extra cull volume in a tree is rotten.

Rough trees.-(a) Live trees of commercial species that do not contain at least one merchantable 12foot saw log or two saw logs 8 feet or longer, now or prospectively, and/or do not meet regional specifications for freedom from defect primarily because of roughness or poor form, and (b) all live trees of noncommercial species.

Roundwood products.-Logs, bolts, or other round sections (including chips from roundwood) cut from trees for industrial or consumer uses. (Note: Includes saw logs, veneer logs and bolts; cooperage logs and bolts; pulpwood; fuelwood; piling; poles; posts; hewn ties; mine timbers; and various other round, split, or hewn products.)

Salvable dead trees.-Standing or down dead trees considered merchantable by regional standards.

Saplings.-Live trees 1.0 to 5.0 inches d.b.h.

Sapling-seedling stands.-(See stand-size class.)

Saw log.-A log meeting minimum standards of diameter, length, and defect, including logs at least 8 feet long, sound and straight and with a minimum diameter outside bark (d.o.b.) for softwoods of 7 inches (9 inches for hardwoods) or other combinations of size and defect specified by regional standards.

Saw log portion.-That part of the bole of sawtimber trees between the stump and the saw log top.

Saw $\log$ top.-The point on the bole of sawtimber trees above which a saw log cannot be produced. The minimum saw log top is 7.0 inches d.o.b. for softwoods and 9.0 inches d.o.b. for hardwoods.

Sawtimber stands.-(See stand-size class.)

Sawtimber trees.-Growing-stock trees of commercial species containing at least a 12-foot saw log or two noncontiguous saw $\operatorname{logs} 8$ feet or longer, and meeting regional specifications for freedom from defect. Softwoods must be at least 9.0 inches d.b.h. Hardwoods must be at least 11.0 inches d.b.h.

Sawtimber volume.-Net volume of the saw $\log$ portion of live sawtimber in board feet, International $1 / 4$-inch rule, from stump to a minimum 7 inches top diameter outside bark (d.o.b.) for softwoods and a minimum 9 inches top d.o.b. for hardwoods.

Seedlings.-Live trees less than 1.0 inch d.b.h. that are expected to survive. Only softwood seedlings more than 6 inches tall and hardwood seedlings more than 1 foot tall are counted.
Short-log (rough tree).-Sawtimber-size trees of commercial species that contain at least one merchantable 8- to 11-foot saw log but not a 12-foot saw $\log$ or two noncontiguious saw logs 8- to 11- feet long.

Shrub biomass.-The total above-ground weight (including the bark) of selected shrubs and trees less than 1 inch d.b.h.

Site class.-A classification of forest land in terms of inherent capacity to grow crops of industrial wood based on fully stocked natural stands.

Site index.-An expression of forest site quality based on the height of a free-growing dominant or codominant tree of a representative species in the forest type at age 50 .

Softwoods.-Coniferous trees, usually evergreen, having needles or scale-like leaves.

Stand.-A growth of trees on a minimum of 1 acre of forest land that is stocked by forest trees of any size.

Stand-age class.-Age of the main stand. Main stand refers to trees of the dominant forest type and stand-size class.

Stand-area class.-The extent of a continuous forested area of the same forest type, stand-size class, and stand-density class.

Stand-size class. - A classification of forest land based on the size class of growing-stock trees on the area; that is, sawtimber, poletimber, or seedlings and saplings.

a. Sawtimber stands.-Stands at least 16.7 percent stocked with growing-stock trees, with half or more of total stocking in sawtimber or poletimber trees, and with sawtimber stocking at least equal to poletimber stocking.

b. Poletimber stands. - Stands at least 16.7 percent stocked with growing-stock trees of which half or more of this stocking is in poletimber and/or sawtimber trees, and with poletimber stocking exceeding that of sawtimber.

c. Sapling-seedling stands._Stands at least 16.7 percent stocked with growing-stock trees of which more than half of the stocking is saplings and/or seedlings.

d. Nonstocked stands.-Stands in which stocking of growing-stock trees is less than 16.7 percent.

State land.-Land either owned by States or leased to them for 50 years or more.

Stocking.-The degree of occupancy of land by trees, measured by basal area and/or the number of trees in a stand by size or age and spacing, compared to the basal area and/or number of trees required to fully utilize the growth potential of the land; that is, the stocking standard. 
A stocking percent of 100 indicates full utilization of the site and is equivalent to 80 square feet of basal area per acre in trees 5 inches d.b.h. and larger. In a stand of trees less than 5 inches d.b.h., a stocking percent of 100 would indicate that the present number of trees is sufficient to produce 80 square feet of basal area per acre when the trees reach 5 inches d.b.h.

Stands are grouped into the following stocking classes:

Overstocked stands. - Stands in which stocking of trees is 134.0 percent or more.

Fully stocked stands.-Stands in which stocking of trees is from 101.0 to 133.9 percent.

Medium stocked stands.-Stands in which stocking of trees is from 61.0 to 100.9 percent.

Poorly stocked stands. - Stands in which stocking of trees is from 16.7 to 60.9 percent.

Nonstocked areas.-Commercial forest land on which stocking of trees is less than 16.7 percent.

Timber removals from growing stock.-The volume of sound wood in growing-stock trees removed annually for forest products (including roundwood products and logging residues) and for other removals.

Timber removals from sawtimber.-The net boardfoot volume of live sawtimber trees removed for forest products annually (including roundwood products and logging residues) and for other removals.

Timber products output.-All timber products cut from roundwood and byproducts of wood manufacturing plants. Roundwood products include logs, bolts, or other round sections cut from growingstock trees, cull trees, salvable dead trees, trees on nonforest land, noncommercial species, saplingsize trees, and limbwood. Byproducts from primary manufacturing plants include slabs, edging, trimmings, miscuts, sawdust, shavings, veneer cores and clippings, and screenings of pulpmills that are used as pulpwood chips or other products.

Tree biomass.-The total aboveground weight (including the bark) of all trees from 1 to 5 inches in d.b.h., and the total aboveground weight (including the bark) from a 1-foot stump for trees more than 5 inches in diameter.
Tree size class.-A classification of trees based on diameter at breast height, including sawtimber trees, poletimber trees, saplings, and seedlings.

Unproductive forest land.-Forest land incapable of producing 20 cubic feet per acre of annual growth or of yielding crops of industrial wood under natural conditions because of adverse site conditions. (Note: Adverse conditions include shallow soil, dry climate, poor drainage, high elevation, steepness, and rockiness).

Upper stem portion.-That part of the bole of sawtimber trees above the saw $\log$ top to a minimum top diameter of 4.0 inches outside bark or to the point where the central stem breaks into limbs.

Urban and other areas.-Areas within the legal boundaries of cities and towns; suburban areas developed for residential, industrial, or recreational purposes; schoolyards, cemeteries, roads; railroads; airports; beaches; powerlines; and other rights-ofway; or other nonforest land not included in any other specified land use class.

Water-(a) Bureau of the Census.-Permanent inland water surfaces, such as lakes, reservoirs, and ponds having at least 40 acres in area; and streams, sloughs, estuaries, and canals at least one-eighth of a statute mile wide.

(b) Noncensus.-Permanent inland water surfaces, such as lakes, reservoirs, and ponds from 139.9 acres in area; and streams, sloughs estuaries, and canals from 120 feet to one-eighth of a statute mile wide.

Wooded pasture.-Improved pasture with more than 16.7 percent stocking in live trees but less than 25 percent stocking in growing-stock trees. Area is currently improved for grazing or there is other evidence of grazing.

Wooded strip.-An acre or more of natural continuous forest land that would otherwise meet survey standards for commercial forest land except that it is less than 120 feet wide.

\section{TABLES}

\section{AREA}

Table 1.-Area of land by land class, 1968 and 1983 Table 2.-Area of land by land use class and county Table 3.-Area of commercial forest land by ownership class and county
Table 4.-Area of commercial forest land by ownership class and site class

Table 5.-Area of commercial forest land by ownership class and stand-volume class

Table 6.-Area of privately owned commercial forest land by ownership class, owner tenure, and size of holding 
Table 7.-Area of commercial forest land by forest type, stand-size class, and ownership class

Table 8.-Area of commercial forest land by forest type and county

Table 9.-Area of commercial forest land by county and stand-size class

Table 10.-Area of commercial forest land by forest type, stand-size class, and site class

Table 11.-Area of commercial forest land by forest type and stand-age class

Table 12.-Area of commercial forest land by forest type and site-index class

Table 13.-Area of commercial forest land by forest type, stand-size class, and basal-area class

Table 14.-Area of commercial forest land by stocking class of growing-stock trees and standsize class

Table 15.-Area of commercial forest land in plantations by forest type and stand-age class

Table 16.-Area of commercial forest land with conifer understory by forest type and conifer understory species

Table 17.-Area of noncommercial forest land by ownership class

Table 18.-Area of noncommercial forest land by forest type

\section{NUMBER OF TREES}

Table 19.-Number of all live trees on commercial forest land by species group and diameter class

Table 20.-Number of growing-stock trees on commercial forest land by species group and diameter class

\section{VOLUME}

Table 21.-Net volume of growing stock on commercial forest land by species group

Table 22.-Net volume of all live trees on commercial forest land by species group and diameter class

Table 23.-Net volume of timber on commercial forest land by class of timber and softwoods and hardwoods

Table 24.-Net volume of growing stock, sawtimber, short-log, and rough and rotten trees on commercial forest land by individual species

Table 25.-Net volume of noncommercial species on commercial forest land by individual species

Table 26.-Net volume of growing stock on commercial forest land by species group and county
Table 27.-Net volume of sawtimber on commercial forest land by species group and county

Table 28.-Net volume of growing stock on commercial forest land by species group and diameter class

Table 29.-Net volume of sawtimber on commercial forest land by species group and diameter class

Table 30.-Net volume of growing stock on commercial forest land by species group and forest type

Table 31.-Net volume of sawtimber on commercial forest land by species group and forest type

Table 32.-Net volume of growing stock on commercial forest land by species group and ownership class

Table 33.-Net volume of sawtimber on commercial forest land by species group and ownership class

Table 34.-Net volume of growing stock on commercial forest land by forest type and stand-age class

Table 35.-Net volume of sawtimber on commercial forest land by forest type and stand-age class

Table 36.-Net volume of growing stock on commercial forest land by forest type, standsize class, and basal-area class

Table 37.-Net volume of sawtimber on commercial forest land by forest type, stand-size class, and basal-area class

Table 38.-Net volume of sawtimber on commercial forest land by species group and butt log grade

Table 39.-Net volume of short-log trees on commercial forest land by species group and diameter class (cubic feet)

Table 40.-Net volume of short-log trees on commercial forest land by species group and diameter class (board feet)

\section{GROWTH AND REMOVALS}

Table 41.-Net annual growth of growing stock on commercial forest land by softwoods and hardwoods

Table 42.-Net annual growth of growing stock on commercial forest land by species group and county

Table 43.-Net annual growth of sawtimber on commercial forest land by species group and county

Table 44.-Net annual growth of growing stock on commercial forest land by ownership class and softwoods and hardwoods 
Table 45.-Net annual growth of growing stock on commercial forest land by species group and type

Table 46.-Net annual growth of sawtimber on commercial forest land by species group and type

Table 47.-Net annual growth of growing stock on commercial forest land by forest type, stand-size class, and basal-area class

Table 48.- Net annual growth of sawtimber on commercial forest land by forest type, standsize class, and basal-area class

Table 49.-Current annual growing-stock removals on commercial forest land by species group and county

Table 50.-Current annual sawtimber removals on commercial forest land by species group and county

Table 51.-A verage annual growing-stock removals on commercial forest land by species group and county

Table 52.-Average annual sawtimber removals on commercial forest land by species group and county

Table 53.-Current annual growing-stock and sawtimber removals on commercial forest land by species group

Table 54.-Current annual growing-stock and sawtimber removals on commercial forest land by item and species category

\section{MORTALITY}

Table 55.-Annual mortality of growing stock on commercial forest land by softwoods and hardwoods, 1967 and 1982

Table 56.-Annual mortality of growing stock on commercial forest land by species group and cause
Table 57.-Annual mortality of sawtimber on commercial forest land by species group and cause

Table 58.-Annual mortality of growing stock and sawtimber on commercial forest land by county and softwoods and hardwoods

Table 59.-Annual mortality of growing stock and sawtimber on commercial forest land by ownership class and softwoods and hardwoods

\section{TIMBER PRODUCTS OUTPUT}

Table 60.-Output of timber products by product, softwoods and hardwoods, and source of material

Table 61.-Output of roundwood products by product, softwoods and hardwoods, and source of material

Table 62.-Timber products from roundwood by species group and product

Table 63.- Volume of primary plant residue by use and type of residue

\section{BIOMASS}

Table 64.-All live tree biomass on commercial forest land by species group and forest type

Table 65.-All live tree biomass by species group and tree biomass component

\section{SAMPLING ERRORS}

Table 66.--Sampling errors for estimates smaller than the Unit totals of growing-stock volume, net growth, removals, and area of commercial forest land

Table 67.-Sampling errors for county totals of growing-stock volume, net growth, removals, and area of commercial forest land. 
Tahle 1..-Area of land by land class, Northwest Unit, Wisconsin, 1968 and 1983

(In thousand acres)

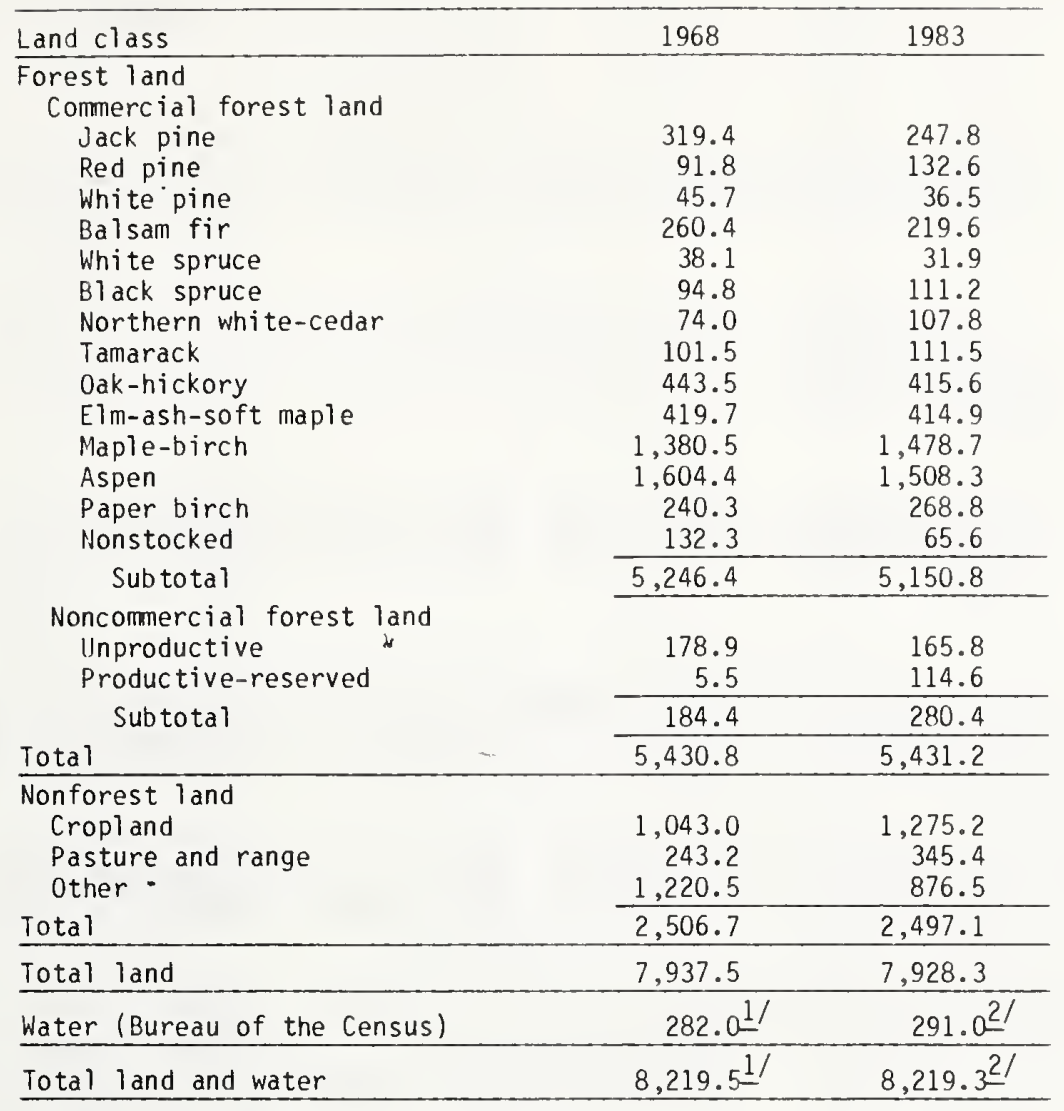

1/U.S. Department of Commerce, Bureau of Census, 1960.

2/U.S. Department of Commerce, Bureau of Census, 1980. 


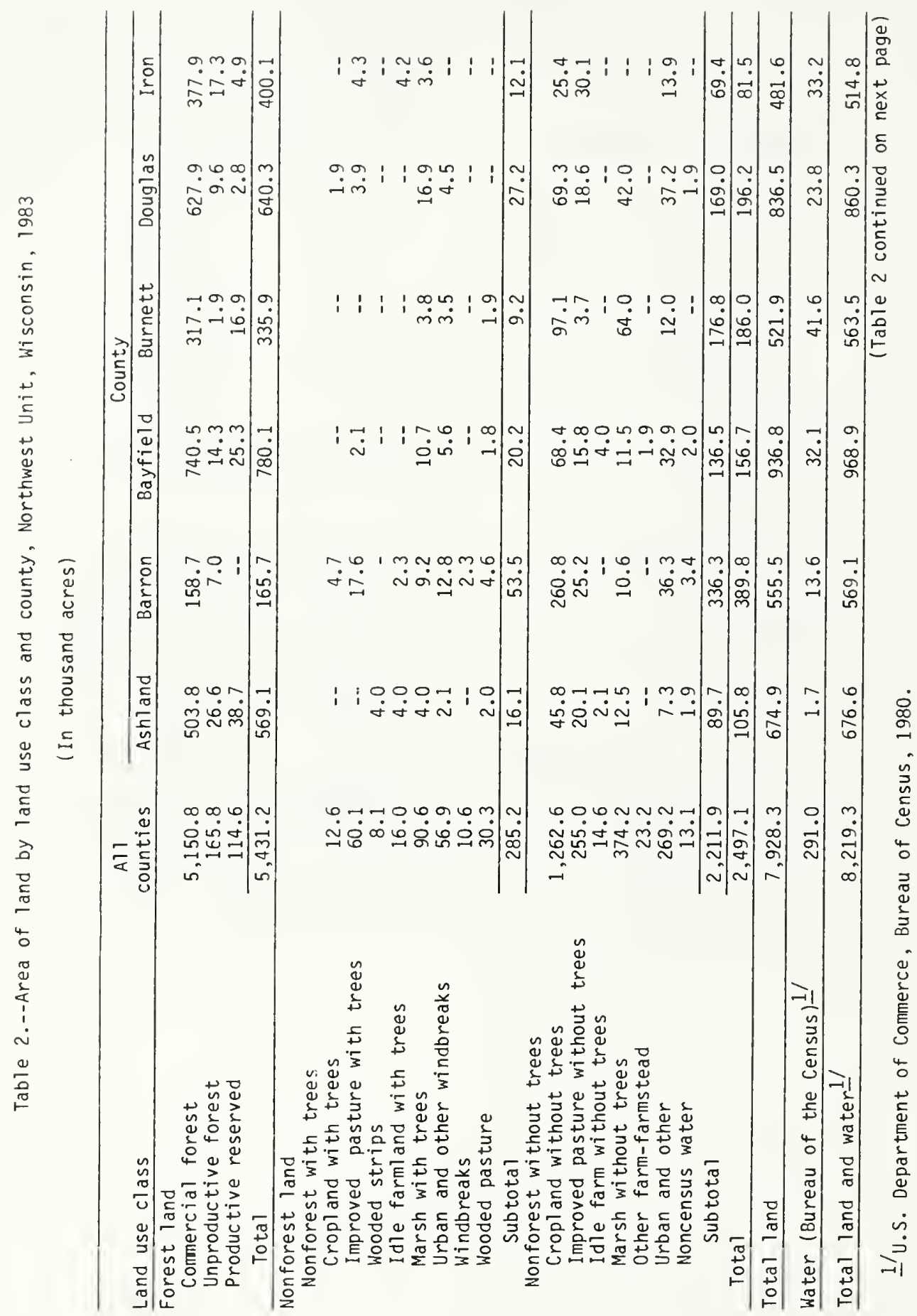




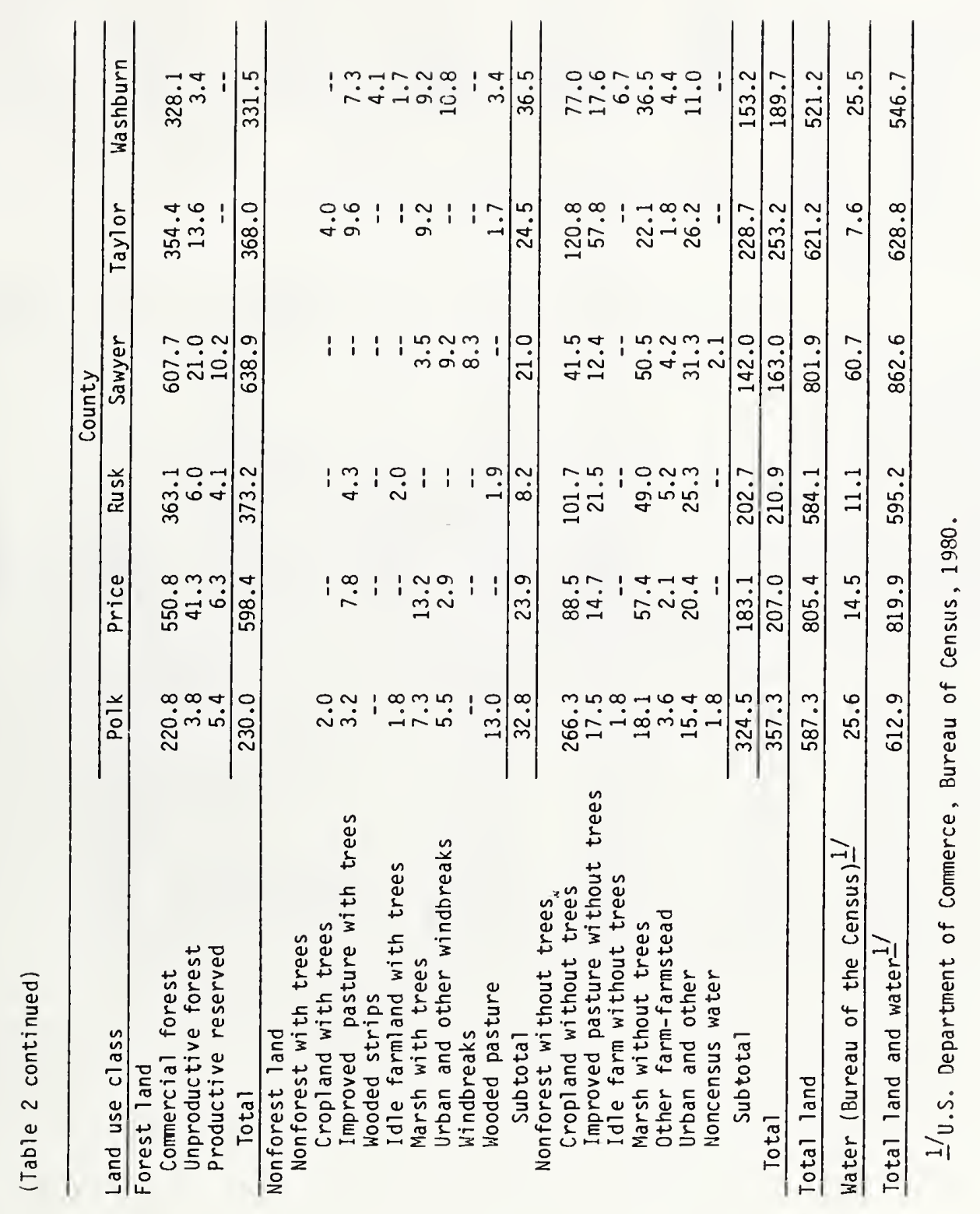


Table 3.--Area of commercial forest land by ownership class and county, Northwest Unit, Wisconsin, 1983

(In thousand acres)

\begin{tabular}{|c|c|c|c|c|c|c|c|}
\hline \multirow[b]{2}{*}{ Ownership class } & \multirow{2}{*}{$\begin{array}{c}\text { All } \\
\text { counties }\end{array}$} & \multicolumn{6}{|c|}{ County } \\
\hline & & Ashitand & Barron & Bayfield & Burnett & Douglas & Iron \\
\hline National Forest & 693.5 & 143.3 & -- & 238.7 & -- & -- & - \\
\hline Miscell aneous federal & 7.3 & -- & -- & -- & 5.6 & -- & -- \\
\hline State & 176.8 & 10.0 & 6.9 & 8.8 & 26.5 & 32.4 & 19.2 \\
\hline County and municipal & $1,109.8$ & 40.6 & 16.1 & 160.6 & 100.2 & 253.8 & 141.7 \\
\hline Indian & 94.6 & 38.5 & -- & 7.2 & - & -- & 10.5 \\
\hline Forest industry & 529.2 & 42.3 & -- & 89.2 & 7.6 & 99.4 & 80.7 \\
\hline Farmer & 450.2 & 26.5 & 55.2 & 41.3 & 45.3 & 30.5 & 10.5 \\
\hline Misc. private-corporation & 224.0 & 46.7 & 6.9 & 17.8 & 5.6 & 28.5 & 24.5 \\
\hline Nisc. private-individual & $1,865.4$ & 155.9 & 73.6 & 176.9 & 126.3 & 183.3 & 90.8 \\
\hline A11 owners & $5,150.8$ & 503.8 & 158.7 & 740.5 & 317.1 & 627.9 & 377.9 \\
\hline
\end{tabular}

(Table 3 continued)

\begin{tabular}{lrrrrrr} 
& \multicolumn{7}{c}{ County } \\
\cline { 3 - 6 } Ownership class & \multicolumn{1}{c}{ Polk } & Price & Rusk & Sawyer & Taylor & Washburn \\
\hline National Forest & -- & 105.2 & -- & 99.0 & 107.3 & -- \\
Miscellaneous federal & -- & -- & -- & 1.7 & -- & -- \\
State & 5.7 & 17.9 & 6.0 & 33.0 & 5.3 & 5.1 \\
County and municipal & 24.4 & 64.4 & 79.6 & 100.5 & 8.9 & 119.0 \\
Indian & -- & -- & -- & 38.4 & -- & -- \\
Forest industry & -- & 39.3 & 51.6 & 98.2 & 9.0 & 11.9 \\
Farmer & 66.7 & 15.9 & 83.0 & 7.0 & 39.4 & 28.9 \\
Misc. private-corporation & 14.7 & 21.5 & 3.9 & 28.2 & 3.6 & 22.1 \\
Misc. private-individual & 109.3 & 286.6 & 139.0 & 201.7 & 180.9 & 141.1 \\
All owners & 220.8 & 550.8 & 363.1 & 607.7 & 354.4 & 328.1 \\
\hline
\end{tabular}


Table 4.--Area of commercial forest land by ownership class and site class, Northwest Unit, Wisconsin, 1983

(In thousand acres)

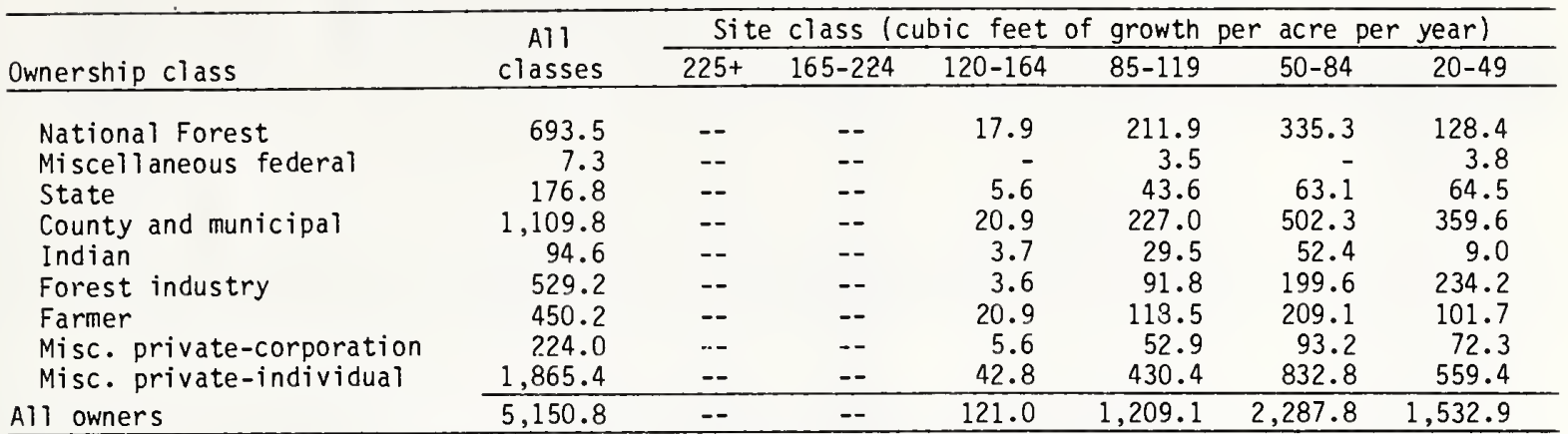

Table 5.--Area of commercial forest land by ownership class and stand-volume class, Northwest Unit, Wisconsin, 1983

(In thousand acres)

\begin{tabular}{lrrrr} 
& & \multicolumn{3}{c}{ Stand-volume class (board feet-1) } \\
\cline { 3 - 5 } Ownership class & All & Less than & 1,500 to \\
& classes & 1,500 & 5,000 & $5,000+$ \\
\hline National Forest & & & & \\
Miscellaneous federal & 693.5 & 287.6 & 320.4 & 85.5 \\
State & 7.3 & 5.4 & 1.9 & -- \\
County and municipal & 176.8 & 85.3 & 76.0 & 15.5 \\
Indian & $1,109.8$ & 545.2 & 451.9 & 112.7 \\
Forest industry & 94.6 & 28.8 & 33.3 & 32.5 \\
Farmer & 529.2 & 285.5 & 189.0 & 54.7 \\
Misc. private-corporation & 450.2 & 234.0 & 170.2 & 46.0 \\
Misc. private-individual & $1,865.4$ & 951.2 & 713.8 & 200.4 \\
\cline { 3 - 6 } All owners & $5,150.8$ & $2,517.5$ & $2,046.8$ & 586.5 \\
\hline
\end{tabular}

1/International $1 / 4-$ inch rule. 
Table 6.--Area of orivately owned commercial forest land by ownership class, owner tenure, and size of holding, Nortnwest Unit, Wisconsin, 1983

(In thousand acres)

\begin{tabular}{|c|c|c|c|c|c|c|c|c|c|c|}
\hline \multirow[b]{2}{*}{$\begin{array}{l}\text { Ownership class } \\
\text { and owner tenure class }\end{array}$} & \multirow[b]{2}{*}{$\begin{array}{l}\text { All } 1 \\
\text { sizes }\end{array}$} & \multicolumn{8}{|c|}{ Size of holding (acres) } & \multirow[b]{2}{*}{$5001+$} \\
\hline & & $1-4$ & $5-10$ & $11-20$ & $21-50$ & $51-100$ & $\begin{array}{l}101- \\
500\end{array}$ & $\begin{array}{r}501- \\
2,500\end{array}$ & $\begin{array}{l}2,501- \\
5,000\end{array}$ & \\
\hline $\begin{array}{r}\text { Forest industry } \\
1-4 \text { years } \\
5-9 \text { years } \\
10-19 \text { years } \\
20+\text { years }\end{array}$ & $\begin{array}{r}37.0 \\
60.8 \\
187.0 \\
244.4 \\
\end{array}$ & $\begin{array}{l}-- \\
-- \\
-- \\
--\end{array}$ & $\begin{array}{l}-- \\
-- \\
-- \\
--\end{array}$ & $\begin{array}{l}-- \\
-- \\
-- \\
-- \\
\end{array}$ & $\begin{array}{l}-- \\
-- \\
-- \\
--\end{array}$ & $\begin{array}{c}3.5 \\
-- \\
-- \\
-- \\
\end{array}$ & $\begin{array}{r}1.9 \\
2.0 \\
2.0 \\
--\end{array}$ & $\begin{array}{l}-- \\
-- \\
7.5 \\
1.9\end{array}$ & $\begin{array}{l}1.8 \\
- \\
7.1 \\
5.3\end{array}$ & $\begin{array}{r}29.8 \\
58.8 \\
170.4 \\
237.2 \\
\end{array}$ \\
\hline All classes & 529.2 & -- & -- & -- & -- & 3.5 & 5.9 & 9.4 & 14.2 & 496.2 \\
\hline $\begin{array}{r}\text { Farmer } \\
1-4 \text { years } \\
5-9 \text { years } \\
10-19 \text { years } \\
20+\text { years }\end{array}$ & $\begin{array}{r}89.4 \\
82.6 \\
149.4 \\
128.8 \\
\end{array}$ & $\begin{array}{l}-- \\
-- \\
-- \\
3.7 \\
\end{array}$ & $\begin{array}{r}5.9 \\
5.6 \\
7.6 \\
11.6 \\
\end{array}$ & $\begin{array}{r}11.7 \\
7.4 \\
7.6 \\
13.6 \\
\end{array}$ & $\begin{array}{l}23.6 \\
16.2 \\
37.1 \\
23.8 \\
\end{array}$ & $\begin{array}{l}19.2 \\
17.0 \\
31.7 \\
31.8 \\
\end{array}$ & $\begin{array}{l}25.6 \\
30.6 \\
63.5 \\
44.3 \\
\end{array}$ & $\begin{array}{r}3.4 \\
5.8 \\
1.9 \\
-- \\
\end{array}$ & $\begin{array}{l}-- \\
-- \\
-- \\
--\end{array}$ & $\begin{array}{l}-- \\
-- \\
-- \\
--\end{array}$ \\
\hline All classes & 450.2 & 3.7 & 30.7 & 40.3 & 100.7 & 99.7 & 164.0 & 11.1 & -- & -- \\
\hline $\begin{array}{l}\text { Misc. priv. -corporation } \\
1-4 \text { years } \\
5-9 \text { years } \\
10-19 \text { years } \\
20+\text { years }\end{array}$ & $\begin{array}{r}47.4 \\
25.1 \\
48.2 \\
103.3 \\
\end{array}$ & $\begin{array}{l}-- \\
-- \\
-- \\
-- \\
\end{array}$ & $\begin{array}{l}-- \\
-- \\
-- \\
-- \\
\end{array}$ & $\begin{array}{l}-- \\
-- \\
-- \\
-- \\
\end{array}$ & $\begin{array}{l}1.8 \\
1.8 \\
5.7 \\
5.5 \\
\end{array}$ & $\begin{array}{l}5.9 \\
1.8 \\
7.6 \\
8.0 \\
\end{array}$ & $\begin{array}{r}13.5 \\
7.1 \\
13.0 \\
25.0 \\
\end{array}$ & $\begin{array}{r}1.7 \\
5.3 \\
9.3 \\
25.5 \\
\end{array}$ & $\begin{array}{r}1.8 \\
1.7 \\
3.4 \\
17.7 \\
\end{array}$ & $\begin{array}{r}22.7 \\
7.4 \\
9.2 \\
21.6 \\
\end{array}$ \\
\hline All classes & 224.0 & -- & -- & -- & 14.8 & 23.3 & 58.6 & 41.8 & 24.6 & 60.9 \\
\hline $\begin{array}{l}\text { Misc. } \text { priv. }- \text { individual } \\
1-4 \text { years } \\
5-9 \text { years } \\
10-19 \text { years } \\
20+\text { years }\end{array}$ & $\begin{array}{l}544.4 \\
409.2 \\
502.1 \\
409.7 \\
\end{array}$ & $\begin{array}{r}9.4 \\
11.2 \\
8.6 \\
3.9 \\
\end{array}$ & $\begin{array}{r}15.8 \\
12.8 \\
9.5 \\
5.7 \\
\end{array}$ & $\begin{array}{l}24.9 \\
22.0 \\
18.9 \\
15.3 \\
\end{array}$ & $\begin{array}{l}181.3 \\
140.1 \\
151.1 \\
110.3 \\
\end{array}$ & $\begin{array}{l}153.8 \\
101.9 \\
113.0 \\
111.0 \\
\end{array}$ & $\begin{array}{l}153.6 \\
115.8 \\
179.5 \\
140.0 \\
\end{array}$ & $\begin{array}{r}3.8 \\
5.4 \\
21.5 \\
23.5 \\
\end{array}$ & $\begin{array}{c}1.8 \\
-- \\
-- \\
-- \\
\end{array}$ & $\begin{array}{l}-- \\
-- \\
-- \\
--\end{array}$ \\
\hline All classes & $1,865.4$ & 33.1 & 43.8 & 81.1 & 582.8 & 479.7 & 588.9 & 54.2 & 1.8 & - \\
\hline $\begin{array}{l}\text { A11 private owners } \\
1-4 \text { years } \\
5-9 \text { years } \\
10-19 \text { years } \\
20+\text { years }\end{array}$ & $\begin{array}{l}718.2 \\
577.7 \\
886.7 \\
886.2 \\
\end{array}$ & $\begin{array}{r}9.4 \\
11.2 \\
8.6 \\
7.6 \\
\end{array}$ & $\begin{array}{l}21.7 \\
18.4 \\
17.1 \\
17.3 \\
\end{array}$ & $\begin{array}{l}36.6 \\
29.4 \\
26.5 \\
28.9 \\
\end{array}$ & $\begin{array}{l}206.7 \\
158.1 \\
193.9 \\
139.6 \\
\end{array}$ & $\begin{array}{l}182.4 \\
120.7 \\
152.3 \\
150.8 \\
\end{array}$ & $\begin{array}{l}194.6 \\
155.5 \\
258.0 \\
209.3 \\
\end{array}$ & $\begin{array}{r}8.9 \\
16.5 \\
40.2 \\
50.9 \\
\end{array}$ & $\begin{array}{r}5.4 \\
1.7 \\
10.5 \\
23.0 \\
\end{array}$ & $\begin{array}{r}52.5 \\
66.2 \\
179.6 \\
258.8 \\
\end{array}$ \\
\hline All classes & $3,068.8$ & 36.8 & 74.5 & 121.4 & 698.3 & 606.2 & 817.4 & 116.5 & 40.6 & 557.1 \\
\hline
\end{tabular}




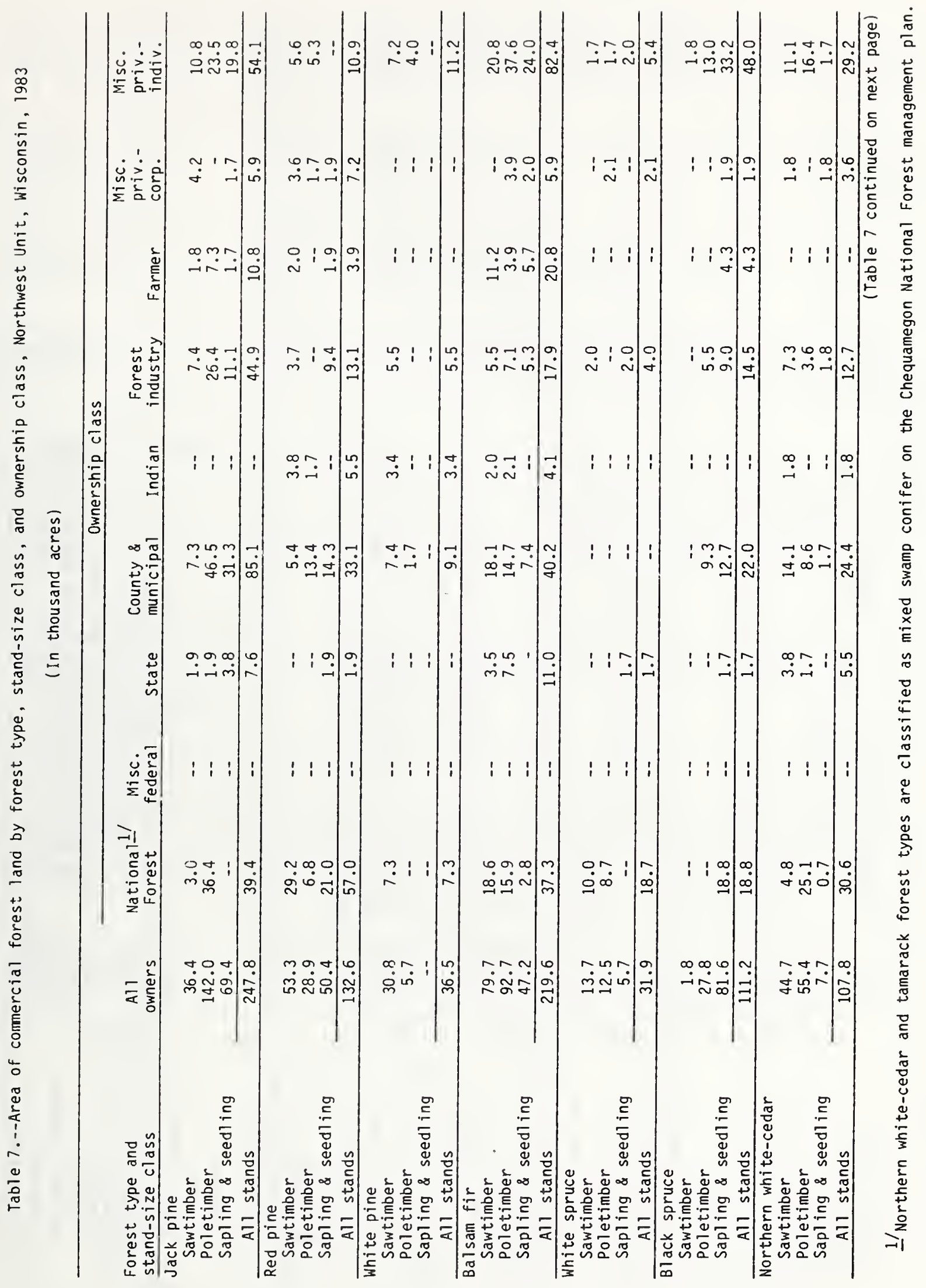




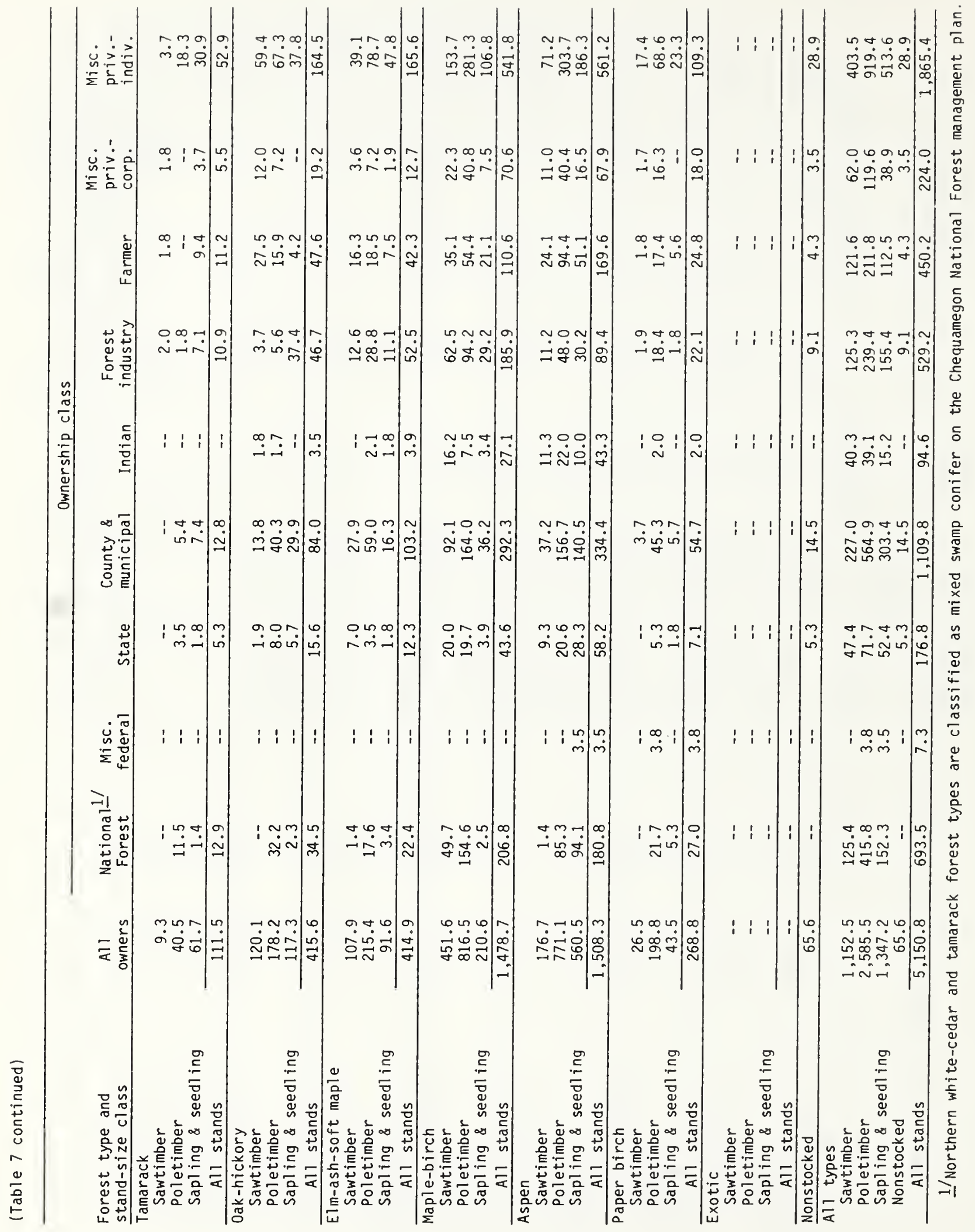


(In thousand acres)

\begin{tabular}{|c|c|c|c|c|c|c|c|}
\hline \multirow[b]{2}{*}{ Forest type } & \multirow{2}{*}{$\begin{array}{c}\text { All } \\
\text { counties }\end{array}$} & \multicolumn{6}{|c|}{ County } \\
\hline & & Ashland & Barron & Bayfield & Burnett & Douglas & Iron \\
\hline Jack pine & 247.8 & 0.7 & 2.3 & 58.1 & 54.6 & 74.2 & -- \\
\hline Red pine & 132.6 & 9.5 & -- & 54.4 & 10.0 & 17.2 & 5.3 \\
\hline White pine & 36.5 & 2.0 & -- & 10.9 & 1.9 & 1.9 & -- \\
\hline Balsam fir & 219.6 & 52.0 & -- & 20.8 & -- & 44.0 & 35.1 \\
\hline White spruce & 31.9 & 14.7 & -- & -- & $-\rightarrow$ & -- & 1.7 \\
\hline Black spruce & 111.2 & 13.9 & 2.3 & 7.1 & 3.8 & 17.1 & 12.4 \\
\hline Northern white-cedar & 107.8 & 22.7 & - & 5.4 & -- & 5.7 & 38.3 \\
\hline Tamarack & 111.5 & 13.4 & 2.3 & 6.2 & 5.7 & 9.5 & 3.6 \\
\hline Oak-hickory & 415.6 & 2.0 & 46.0 & 66.8 & 79.0 & 59.4 & 5.2 \\
\hline Elm-ash-soft maple & 414.9 & 26.9 & 9.2 & 33.6 & 29.2 & 57.2 & 27.9 \\
\hline Maple-birch & $1,478.7$ & 187.8 & 34.5 & 167.3 & 21.6 & 74.3 & 159.3 \\
\hline Aspen & $1,508.3$ & 138.1 & 46.0 & 253.7 & 90.4 & 208.4 & 71.8 \\
\hline Paper birch & 268.8 & 20.1 & 13.8 & 54.4 & 13.3 & 49.6 & 17.3 \\
\hline Exotic & -- & -- & -- & -- & -- & -- & -- \\
\hline Nonstocked & 65.6 & -- & 2.3 & 1.8 & 7.6 & 9.4 & -- \\
\hline Al1 types & $5,150.8$ & 503.8 & 158.7 & 740.5 & 317.1 & 627.9 & 377.9 \\
\hline
\end{tabular}

(Table 8 continued)

\begin{tabular}{|c|c|c|c|c|c|c|}
\hline \multirow[b]{2}{*}{ Forest type } & \multicolumn{6}{|c|}{ County } \\
\hline & Polk & Price & Rusk & Sawyer & Tayl or & Washburn \\
\hline Jack pine & 13.2 & 2.2 & -- & 1.7 & -- & 40.8 \\
\hline Red pine & -- & 12.0 & 3.9 & 13.4 & 1.8 & 5.1 \\
\hline White pine & -- & -- & 6.0 & 12.1 & - & 1.7 \\
\hline Balsam fir & -- & 41.8 & 2.0 & 15.4 & 8.5 & -- \\
\hline White spruce & -- & 3.1 & -- & 8.8 & 3.6 & -- \\
\hline Black spruce & -- & 14.6 & 10.0 & 20.4 & 6.2 & 3.4 \\
\hline Northern white-cedar & -- & 17.4 & 2.0 & 9.4 & 3.5 & 3.4 \\
\hline Tamarack & 5.4 & 28.5 & 2.0 & 10.2 & 14.5 & 10.2 \\
\hline Oak-hickory & 66.9 & -- & 18.0 & 26.4 & -- & 45.9 \\
\hline Elm-ash-soft maple & 14.9 & 60.5 & 43.8 & 45.4 & 42.5 & 23.8 \\
\hline Maple-birch & 59.2 & 174.4 & 132.9 & 249.1 & 163.9 & 54.4 \\
\hline Aspen & 53.9 & 166.2 & 120.7 & 151.6 & 83.4 & 124.1 \\
\hline Paper birch & 7.3 & 17.6 & 17.8 & 28.3 & 15.7 & 13.6 \\
\hline Exotic & -- & -- & -- & -- & -- & -- \\
\hline Nonstocked & -- & 12.5 & 4.0 & 15.5 & 10.8 & 1.7 \\
\hline Al1 types & 220.8 & 550.8 & 363.1 & 607.7 & 354.4 & 328.1 \\
\hline
\end{tabular}

Table 9.--Area of commercial forest land by county and stand-size class, Northwest Unit, Wisconsin, 1983

(In thousand acres)

\begin{tabular}{lrrrrr}
\hline & & \multicolumn{4}{c}{ Stand-size class } \\
\cline { 3 - 5 } County & $\begin{array}{c}\text { Al1 } \\
\text { stands }\end{array}$ & $\begin{array}{c}\text { Sawtimber } \\
\text { stands }\end{array}$ & $\begin{array}{c}\text { Poletimber } \\
\text { stands }\end{array}$ & $\begin{array}{c}\text { Sapling and } \\
\text { seedling stands }\end{array}$ & $\begin{array}{c}\text { Nonstocked } \\
\text { areas }\end{array}$ \\
\hline Ashland & 503.8 & 135.9 & 263.6 & 104.3 & - \\
Barron & 158.7 & 57.5 & 64.4 & 34.5 & 2.3 \\
Bayfield & 740.5 & 144.0 & 407.2 & 187.5 & 1.8 \\
Burnett & 317.1 & 74.5 & 133.3 & 101.7 & 7.6 \\
Douglas & 627.9 & 106.5 & 301.7 & 210.3 & 9.4 \\
Iron & 377.9 & 108.5 & 192.0 & 77.4 & - \\
Polk & 220.8 & 64.7 & 98.4 & 57.7 & - \\
Price & 550.8 & 97.9 & 256.6 & 183.8 & 12.5 \\
Rusk & 363.1 & 103.0 & 192.4 & 63.7 & 4.0 \\
Sawyer & 607.7 & 162.1 & 312.9 & 117.2 & 15.5 \\
Taylor & 354.4 & 52.0 & 179.4 & 112.2 & 10.8 \\
Washburn & 328.1 & 45.9 & 183.6 & 96.9 & 1.7 \\
All counties & $5,150.8$ & $1,152.5$ & $2,585.5$ & $1,347.2$ & 65.6 \\
\hline
\end{tabular}


Table 10.--Area of commercial forest land by forest type, stand-size class, and site class, Northwest Unit, Wisconsin, 1983

(In thousand acres)

\begin{tabular}{|c|c|c|c|c|c|c|c|}
\hline Forest type and & Al1 & Site & class (c) & bic feet of & growth per & acre per & year) \\
\hline stand-size class & classes & $225+$ & $165-224$ & $120-164$ & $85-119$ & $50-84$ & $20-49$ \\
\hline $\begin{array}{l}\text { Jack pine } \\
\text { Sawtimber } \\
\text { Poletimber } \\
\text { Sapling \& seedling }\end{array}$ & $\begin{array}{r}36.4 \\
142.0 \\
69.4 \\
\end{array}$ & $\begin{array}{l}-- \\
-- \\
--\end{array}$ & $\begin{array}{l}-- \\
-- \\
-- \\
\end{array}$ & $\begin{array}{r}-- \\
1.9 \\
\end{array}$ & $\begin{array}{l}7.0 \\
5.7 \\
3.6 \\
\end{array}$ & $\begin{array}{l}16.6 \\
75.2 \\
29.3 \\
\end{array}$ & $\begin{array}{l}12.8 \\
61.1 \\
34.6 \\
\end{array}$ \\
\hline All stands & 247.8 & -- & -- & 1.9 & 16.3 & 121.1 & 108.5 \\
\hline $\begin{array}{l}\text { Red pine } \\
\text { Sawtimber } \\
\text { Poletimber } \\
\text { Sapl ing \& seedling }\end{array}$ & $\begin{array}{l}53.3 \\
28.9 \\
50.4 \\
\end{array}$ & $\begin{array}{l}-- \\
-- \\
--\end{array}$ & $\begin{array}{l}-- \\
-- \\
--\end{array}$ & $\begin{array}{l}3.4 \\
3.5 \\
1.9 \\
\end{array}$ & $\begin{array}{l}37.5 \\
23.6 \\
11.1 \\
\end{array}$ & $\begin{array}{r}7.4 \\
1.8 \\
29.4 \\
\end{array}$ & $\begin{array}{r}-- \\
-- \\
8.0\end{array}$ \\
\hline A11 stands & 132.6 & -- & -- & 13.8 & 72.2 & 38.6 & 8.0 \\
\hline $\begin{array}{l}\text { White pine } \\
\text { Sawtimber } \\
\text { Poletimber } \\
\text { Sapling \& seedling }\end{array}$ & $\begin{array}{r}30.8 \\
5.7 \\
-- \\
\end{array}$ & $\begin{array}{l}-- \\
-- \\
--\end{array}$ & $\begin{array}{l}-- \\
-- \\
-\end{array}$ & $\begin{array}{r}3.4 \\
-- \\
-- \\
\end{array}$ & $\begin{array}{r}9.1 \\
-- \\
-- \\
\end{array}$ & $\begin{array}{r}16.6 \\
3.7 \\
-- \\
\end{array}$ & $\begin{array}{r}1.7 \\
2.0 \\
-= \\
\end{array}$ \\
\hline All stands & 36.5 & -- & $=$ & 3.4 & 9.1 & 20.3 & 3.7 \\
\hline $\begin{array}{l}\text { Balsam fir } \\
\text { Sawtimber } \\
\text { Poletimber } \\
\text { Sapling \& seedling }\end{array}$ & $\begin{array}{l}79.7 \\
92.7 \\
47.2 \\
\end{array}$ & -- & $\begin{array}{l}-- \\
-- \\
- \\
\end{array}$ & $\begin{array}{l}38.6 \\
19.0 \\
15.8 \\
\end{array}$ & $\begin{array}{l}19.8 \\
42.3 \\
11.2 \\
\end{array}$ & $\begin{array}{l}14.3 \\
22.1 \\
12.9 \\
\end{array}$ & $\begin{array}{l}7.0 \\
9.3 \\
7.3 \\
\end{array}$ \\
\hline All stands & 219.6 & -- & - & 73.4 & 73.3 & 49.3 & 23.6 \\
\hline $\begin{array}{l}\text { White spruce } \\
\text { Sawtimber } \\
\text { Poletimber } \\
\text { Sapling \& seedling }\end{array}$ & $\begin{array}{r}13.7 \\
12.5 \\
5.7 \\
\end{array}$ & $\begin{array}{l}-- \\
-- \\
-- \\
\end{array}$ & $\begin{array}{l}-- \\
-- \\
-- \\
\end{array}$ & $\begin{array}{l}-- \\
-- \\
-- \\
\end{array}$ & $\begin{array}{r}13.7 \\
8.7 \\
2.0 \\
\end{array}$ & $\begin{array}{l}--- \\
3.8 \\
2.0 \\
\end{array}$ & $\begin{array}{r}-- \\
-\overline{1.7} \\
\end{array}$ \\
\hline All stands & 31.9 & -- & -- & -- & 24.4 & 5.8 & 1.7 \\
\hline $\begin{array}{l}\text { Black spruce } \\
\text { Sawtimber } \\
\text { poletimber } \\
\text { Sapling \& seedling }\end{array}$ & $\begin{array}{r}1.8 \\
27.8 \\
81.6 \\
\end{array}$ & $\begin{array}{l}-- \\
-- \\
- \\
\end{array}$ & $\begin{array}{l}-- \\
-- \\
--\end{array}$ & $\begin{array}{l}-- \\
-- \\
--\end{array}$ & $\begin{array}{l}-- \\
3.5 \\
1.3 \\
\end{array}$ & $\begin{array}{r}1.8 \\
-- \\
2.0 \\
\end{array}$ & $\begin{array}{l}-- \\
24.3 \\
78.3 \\
\end{array}$ \\
\hline All stands & 111.2 & -- & -- & -- & 4.8 & 3.8 & 102.6 \\
\hline $\begin{array}{l}\text { Northern white-cedar } \\
\text { Sawtimber } \\
\text { Poletimber } \\
\text { Sapling \& seedling }\end{array}$ & $\begin{array}{r}44.7 \\
55.4 \\
7.7 \\
\end{array}$ & $\begin{array}{l}-- \\
-- \\
-- \\
\end{array}$ & $\begin{array}{l}-- \\
-- \\
-- \\
\end{array}$ & $\begin{array}{l}-- \\
-- \\
-\end{array}$ & $\begin{array}{l}-- \\
-- \\
-- \\
\end{array}$ & $\begin{array}{r}15.8 \\
10.8 \\
-- \\
\end{array}$ & $\begin{array}{r}28.9 \\
44.6 \\
7.7 \\
\end{array}$ \\
\hline A11 stands & 107.8 & -- & -- & -- & -- & 26.6 & 81.2 \\
\hline
\end{tabular}


(Table 10 continued)

\begin{tabular}{|c|c|c|c|c|c|c|c|}
\hline \multirow{2}{*}{$\begin{array}{l}\text { Forest type and } \\
\text { stand-size class }\end{array}$} & \multirow{2}{*}{$\begin{array}{c}\text { All } \\
\text { classes }\end{array}$} & Site & \multicolumn{2}{|c|}{ class (cubic feet } & \multirow{2}{*}{ of growth } & \multicolumn{2}{|c|}{ (acre per year) } \\
\hline & & $225+$ & $165-224$ & $120-164$ & & $50-84$ & $20-49$ \\
\hline \multicolumn{8}{|l|}{ Tamarack } \\
\hline Sawtimber & 9.3 & -- & -- & -- & 1.9 & 3.6 & 3.8 \\
\hline Poletimber & 40.5 & -- & -- & -- & 1.7 & 16.9 & 21.9 \\
\hline Sapling \& seedling & 61.7 & -- & -- & -- & 1.7 & 18.5 & 41.5 \\
\hline All stands & 111.5 & - & - & -- & 5.3 & 39.0 & 67.2 \\
\hline \multicolumn{8}{|l|}{ 0ak-hickory } \\
\hline Sawtimber & 120.1 & - & -- & -- & 14.0 & 79.2 & 26.9 \\
\hline Poletimber & 178.2 & -- & -- & -- & 30.2 & 117.3 & 30.7 \\
\hline Sapling \& seedling & 117.3 & $=$ & -- & -- & 10.2 & 55.3 & 51.8 \\
\hline All stands & 415.6 & -- & -- & -- & 54.4 & 251.8 & 109.4 \\
\hline \multicolumn{8}{|l|}{ Elm-ash-soft maple } \\
\hline Sawtimber & 107.9 & -- & -- & -- & 5.8 & 15.8 & 86.3 \\
\hline Poletimber & 215.4 & -- & -- & -- & 13.9 & 50.7 & 150.8 \\
\hline Sapling \& seedling & 91.6 & -- & -- & -- & 1.8 & 9.6 & 80.2 \\
\hline All stands & 414.9 & -- & -- & -- & 21.5 & 76.1 & 317.3 \\
\hline \multicolumn{8}{|l|}{ Maple-birch } \\
\hline Sawtimber & 451.6 & -- & -- & -- & 78.3 & 237.0 & 136.3 \\
\hline Poletimber & 816.5 & -- & -- & 1.8 & 127.6 & 453.2 & 233.9 \\
\hline Sapling \& seedling & 210.6 & -- & $=$ & -- & 20.5 & 113.0 & 77.1 \\
\hline All stands & $1,478.7$ & -- & -- & 1.8 & 226.4 & 803.2 & 447.3 \\
\hline \multicolumn{8}{|l|}{$\overline{\text { Aspen }}$} \\
\hline Sawtimber & 176.7 & -- & -- & 7.2 & 78.6 & 85.6 & 5.3 \\
\hline Poletimber & 771.1 & -- & -- & 11.7 & 371.1 & 357.2 & 31.1 \\
\hline Sapl ing \& seedling & 560.5 & -- & -- & 5.9 & 218.4 & 254.5 & 81.7 \\
\hline All stands & $1,508.3$ & -- & -- & 24.8 & 668.1 & 697.3 & 118.1 \\
\hline \multicolumn{8}{|l|}{ Paper birch } \\
\hline Sawtimber & 26.5 & -- & - & -- & 1.8 & 8.2 & 16.5 \\
\hline Poletimber & 198.8 & -- & -- & 1.9 & 22.4 & 99.3 & 75.2 \\
\hline Sapling \& seedling & 43.5 & -- & -- & -- & 3.7 & 16.2 & 23.6 \\
\hline All stands & 268.8 & -- & -- & 1.9 & 27.9 & 123.7 & 115.3 \\
\hline \multicolumn{8}{|l|}{$\overline{\text { Exotic }}$} \\
\hline Sawtimber & -- & -- & -- & -- & -- & -- & -- \\
\hline Poletimber & -- & $-\infty$ & -- & -- & -- & -- & -- \\
\hline Sapling \& seedling & -- & -- & -- & -- & - & -- & - \\
\hline Al1 stands & -- & -- & -- & -- & -- & -- & -- \\
\hline Nonstocked & 65.6 & -- & -- & -- & 5.4 & 31.2 & 29.0 \\
\hline \multicolumn{8}{|l|}{ A11 types } \\
\hline Sawtimber & $1,152.5$ & -- & -- & 57.6 & 267.5 & 501.9 & 325.5 \\
\hline Poletimber & $2,585.5$ & $\cdots$ & -- & 37.9 & 650.7 & $1,212.0$ & 684.9 \\
\hline Sapling \& seedling & $1,347.2$ & -- & -- & 25.5 & 285.5 & 542.7 & 493.5 \\
\hline Nonstocked & 65.6 & -- & -- & -- & 5.4 & 31.2 & 29.0 \\
\hline Al1 stands & $5,150.8$ & -- & $=$ & 121.0 & $1,209.1$ & $2,287.8$ & $1,532.9$ \\
\hline
\end{tabular}



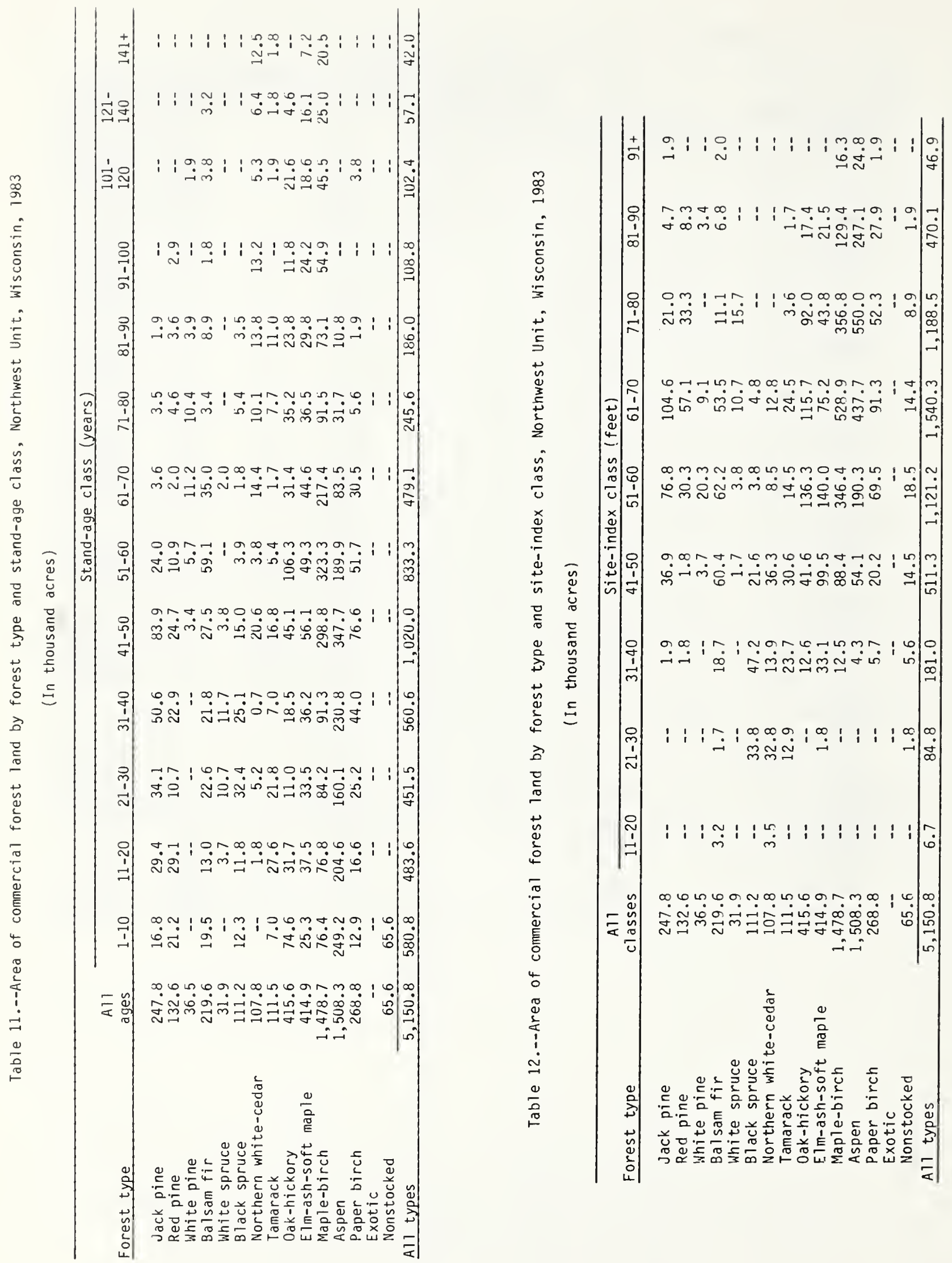


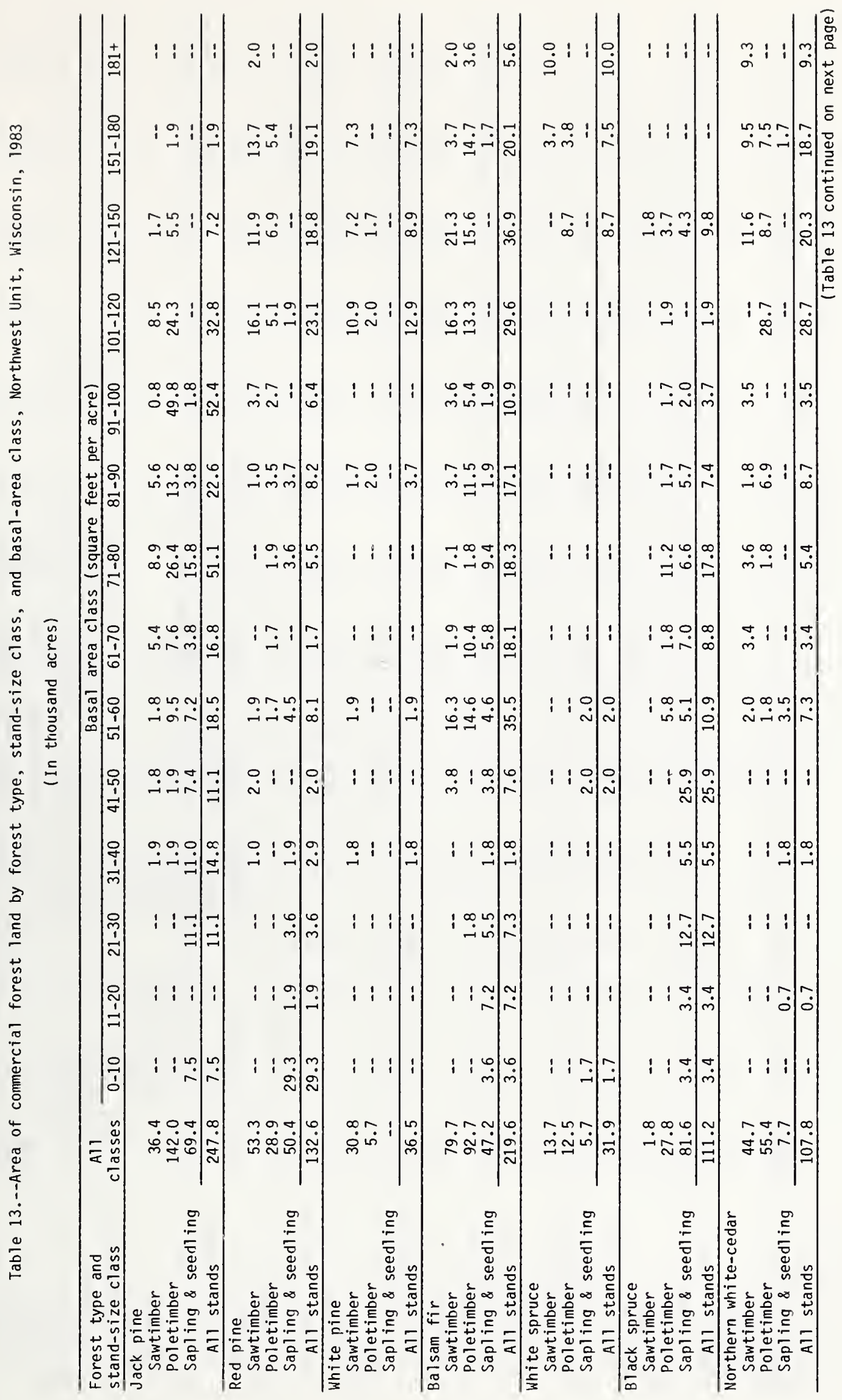




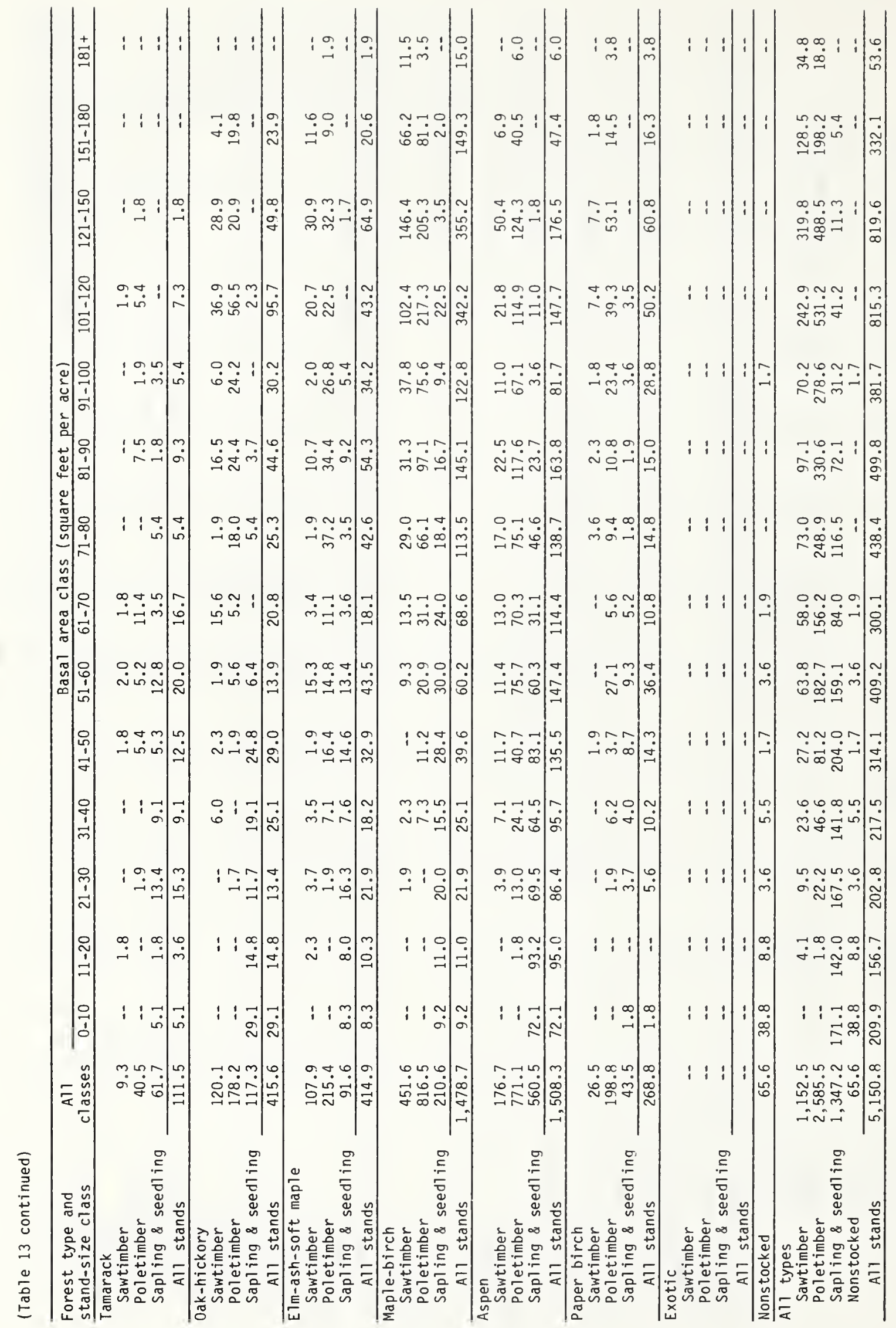



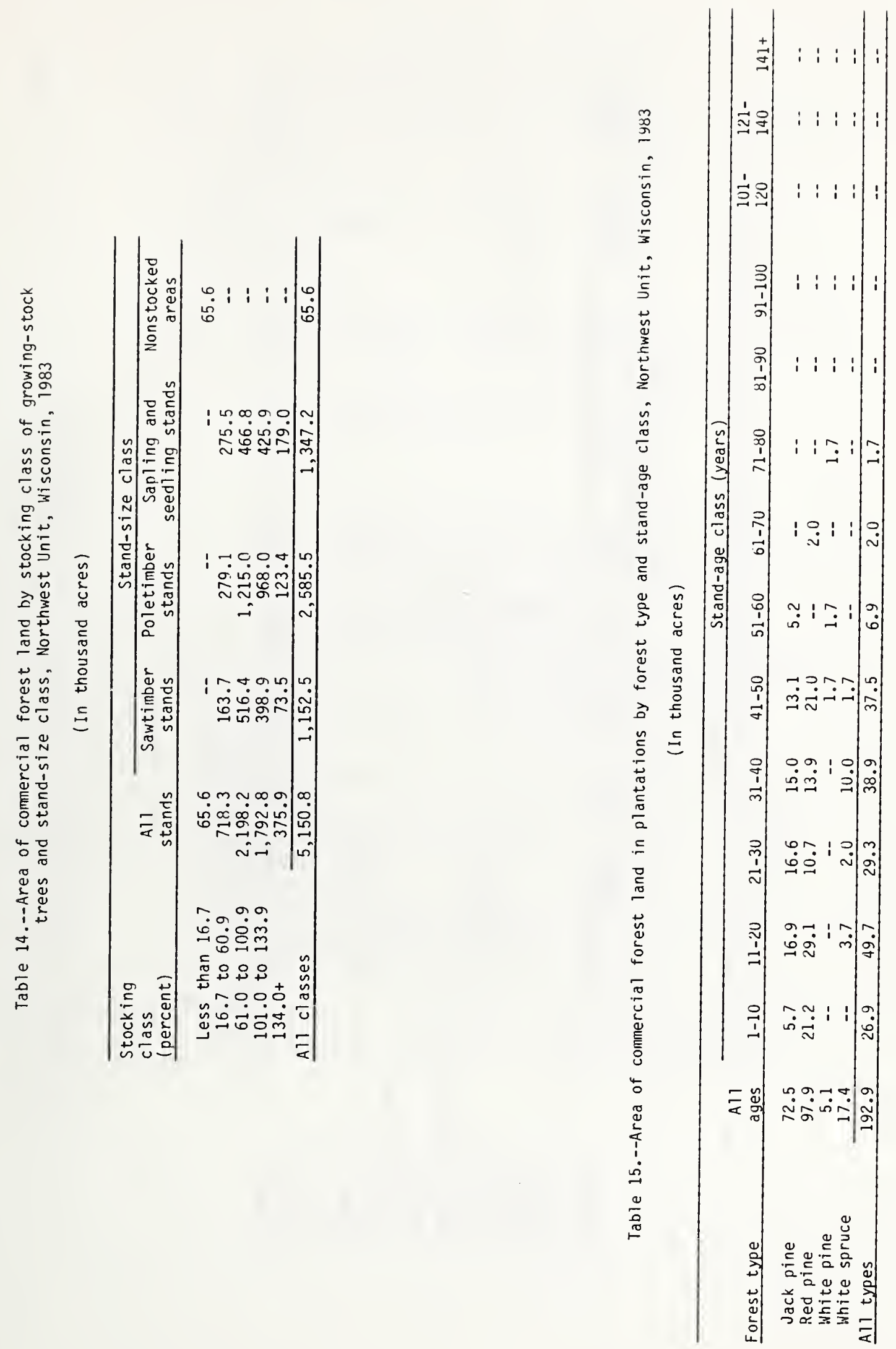


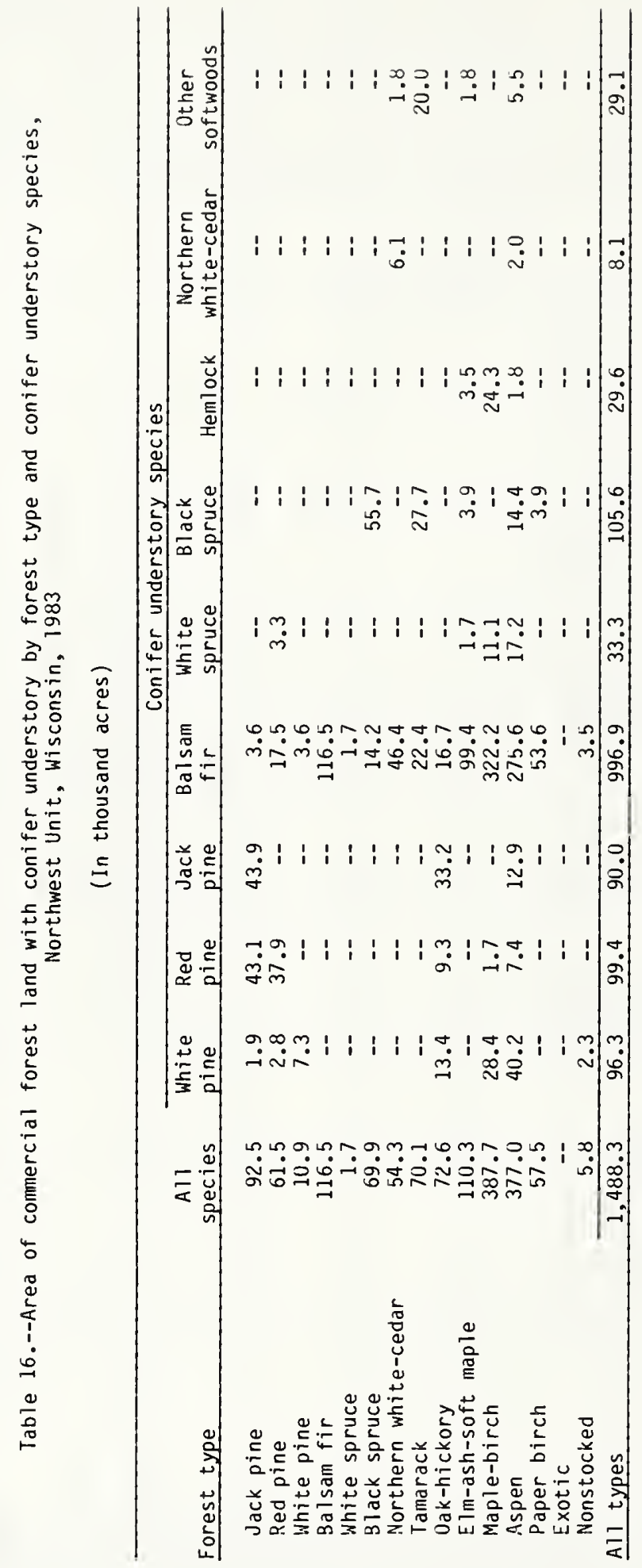


Table 17.--Area of noncommercial forest land by ownership class, Northwest Unit, Wisconsin, 1983

(In thousand acres)

\begin{tabular}{lrrr}
\hline Ownership class & $\begin{array}{c}\text { Ali } \\
\text { areas }\end{array}$ & $\begin{array}{c}\text { Productive- } \\
\text { reserved areas }\end{array}$ & $\begin{array}{c}\text { Unproductive } \\
\text { areas }\end{array}$ \\
\hline National Forest & 86.7 & 24.1 & $1 /$ \\
Miscellaneous federal & 45.0 & 45.0 & 62.6 \\
State & 58.0 & 39.8 & -- \\
County and municipal & 24.9 & 5.7 & 18.2 \\
Indian & 2.2 & -- & 19.2 \\
Forest industry & 5.3 & -- & 2.2 \\
Farmer & 39.3 & -- & 5.3 \\
Misc. private-corp. & 1.8 & -- & 1.8 \\
Misc. private-indiv. & 17.2 & - & 17.2 \\
Total & 280.4 & 114.6 & 165.8 \\
\hline
\end{tabular}

1/Includes 17.0 thousand acres of productive-deferred areas.

Table 18.--Area of noncommercial forest land by forest type, Northwest Unit, Wisconsin, 1983

(In thousand acres)

\begin{tabular}{lrrr}
\hline Forest type & $\begin{array}{c}\text { All } \\
\text { areas }\end{array}$ & $\begin{array}{c}\text { Productive- i/ } \\
\text { reserved areas }\end{array}$ & $\begin{array}{c}\text { Unproductive } \\
\text { areas }\end{array}$ \\
\hline Jack pine & 2.6 & 2.6 & -- \\
Red pine & -- & -- & -- \\
White pine & -- & -- & -- \\
Bal sam fir & 7.8 & 0.9 & 6.9 \\
White spruce & -- & -- & -- \\
Black spruce & 113.2 & 6.9 & 106.3 \\
Northern white-cedar & 4.5 & 0.7 & 3.8 \\
Tamarack & 10.0 & -- & 10.0 \\
Oak-hickory & 7.1 & 5.1 & 2.0 \\
Elm-ash-soft maple & 50.9 & 16.0 & 34.9 \\
Maple-birch & 42.6 & 42.6 & -- \\
Aspen & 38.6 & 38.6 & -- \\
Paper birch & 1.2 & 1.2 & -- \\
Exotic & -- & -- & 1.9 \\
Nonstocked & 1.9 & -- & 165.8 \\
\hline All types & 280.4 & 114.6 & \\
\hline
\end{tabular}

$\underline{1}$ Includes 17.0 thousand acres of productive-deferred areas. 


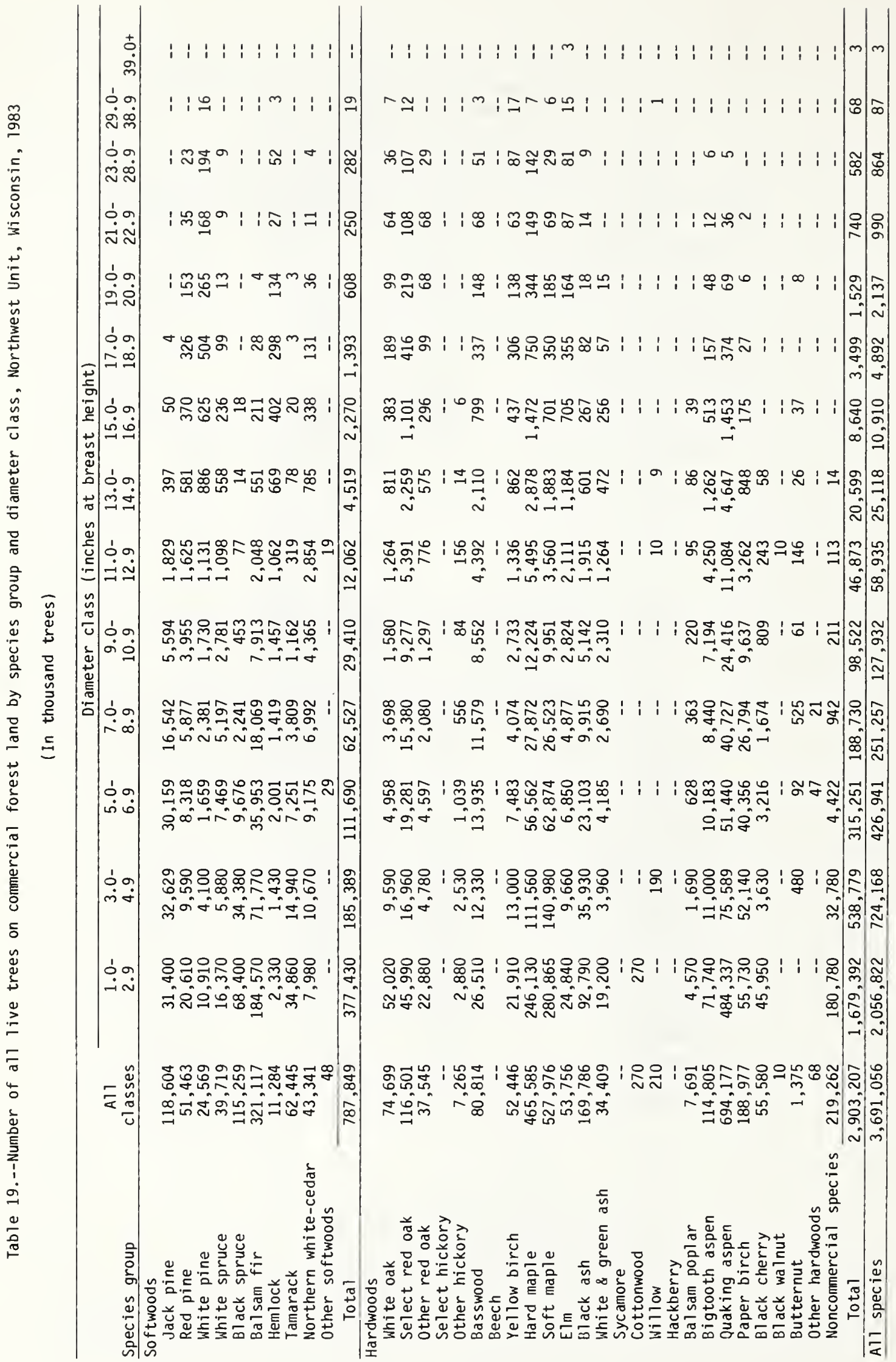




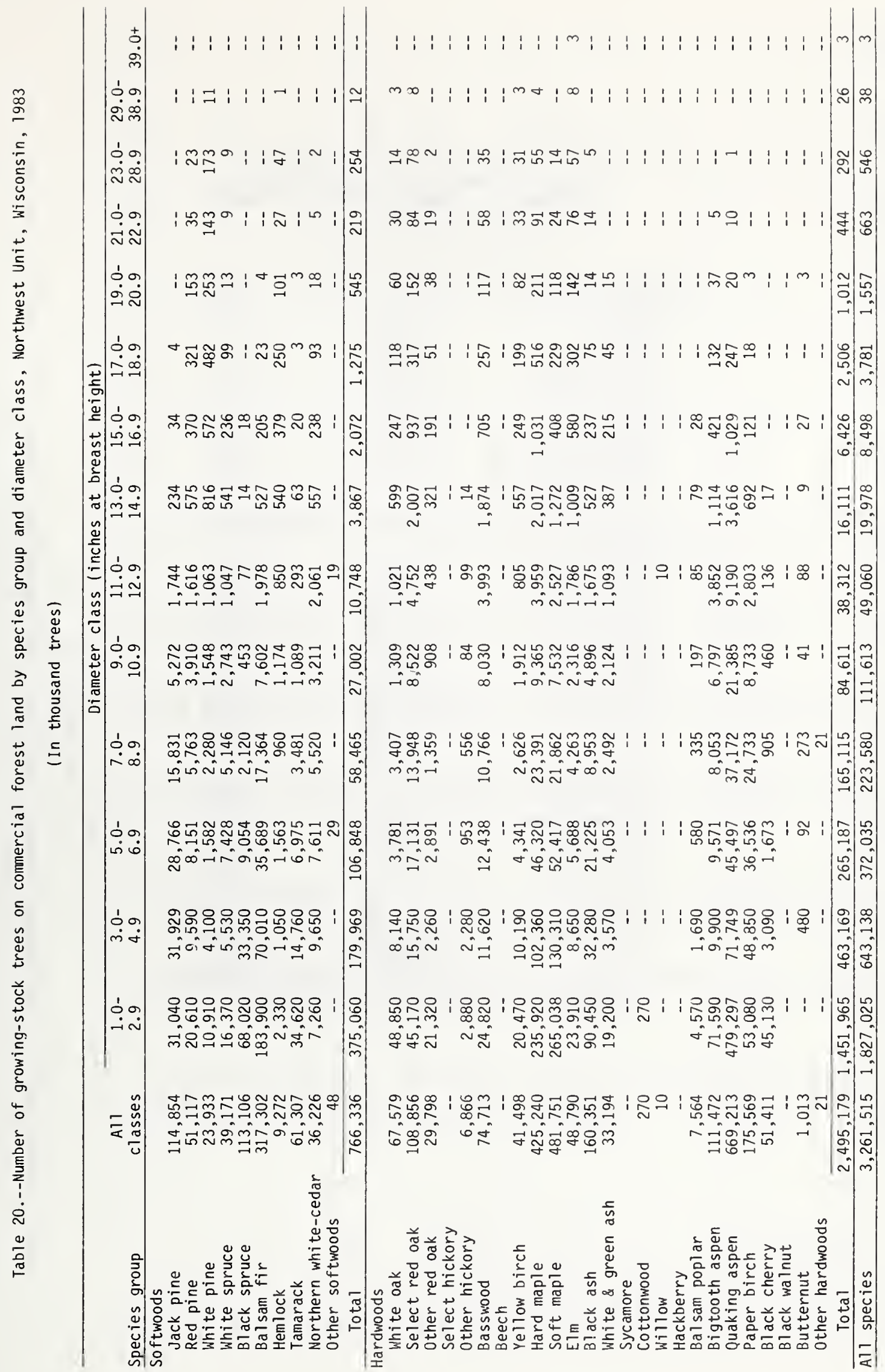


Table 21.--Net volume of growing stock on commercial forest 1 and by species group, Northwest Unit, Wisconsin, 1968 and 1983

(In thousand cubic feet)

\begin{tabular}{|c|c|c|}
\hline Species group & 1968 & 1983 \\
\hline $\begin{array}{l}\text { Softwoods } \\
\text { Jack pine } \\
\text { Red pine } \\
\text { White pine } \\
\text { White spruce } \\
\text { Black spruce } \\
\text { Balsam fir } \\
\text { Hemlock } \\
\text { Tamarack } \\
\text { Northern white-cedar } \\
\text { Other softwoods }\end{array}$ & $\begin{array}{r}188,200 \\
80,000 \\
107,300 \\
33,400 \\
27,900 \\
223,600 \\
77,900 \\
63,900 \\
108,900 \\
--\end{array}$ & $\begin{array}{r}237,849 \\
179,071 \\
154,382 \\
121,342 \\
41,303 \\
299,183 \\
66,348 \\
59,582 \\
124,494 \\
325\end{array}$ \\
\hline Total & 911,100 & $1,283,879$ \\
\hline $\begin{array}{l}\text { Hardwoods } \\
\text { White oak } \\
\text { Select red oak } \\
\text { Other red oak } \\
\text { Hickory } \\
\text { Basswood } \\
\text { Beech } \\
\text { Yellow birch } \\
\text { Hard maple } \\
\text { Soft maple } \\
\text { Elm } \\
\text { Ash } \\
\text { Cottonwood } \\
\text { Willow } \\
\text { Balsam poplar } \\
\text { Bigtooth aspen } \\
\text { Quaking aspen } \\
\text { Paper birch } \\
\text { Black cherry } \\
\text { Black walnut } \\
\text { Butternut } \\
\text { Other hardwoods }\end{array}$ & $\begin{array}{r}51,500 \\
227,500 \\
39,100 \\
2,500 \\
241,300 \\
-- \\
94,800 \\
376,700 \\
241,000 \\
164,200 \\
220,500 \\
100 \\
-. \\
6,400 \\
198,900 \\
780,600 \\
326,800 \\
11,700 \\
-- \\
3,100 \\
300 \\
\end{array}$ & $\begin{array}{r}73,731 \\
392,975 \\
41,248 \\
9,803 \\
334,289 \\
-- \\
85,401 \\
553,791 \\
468,019 \\
141,996 \\
310,079 \\
-- \\
163 \\
8,547 \\
272,055 \\
872,273 \\
438,362 \\
19,820 \\
-- \\
4,841 \\
118\end{array}$ \\
\hline Total & $2,987,000$ & $4,027,511$ \\
\hline All species & $3,898,100$ & $5,311,390$ \\
\hline
\end{tabular}




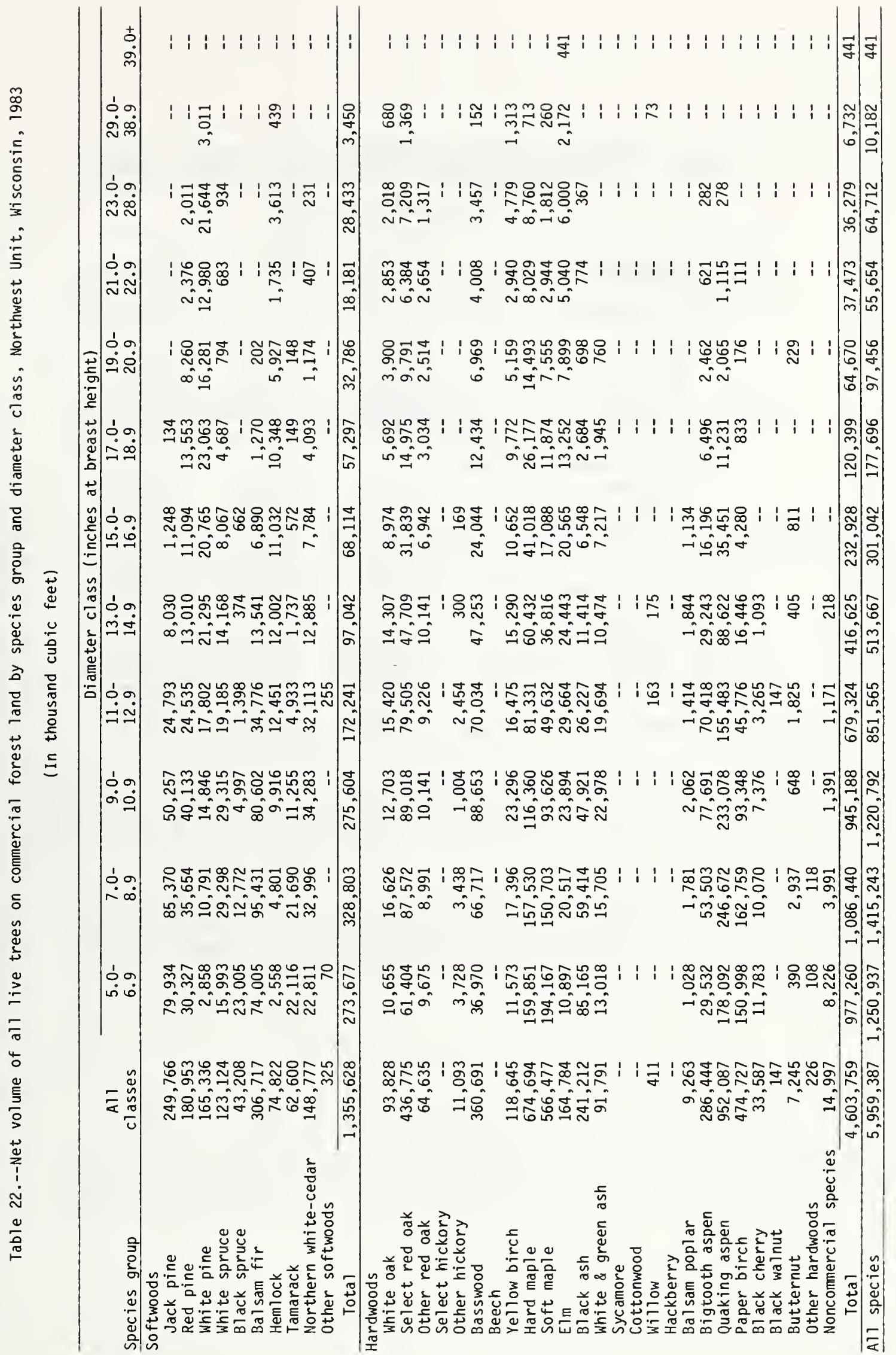


Table 23.--Net volume of timber on commercial forest land by class of timber and softwoods and hardwoods, Northwest Unit, Wisconsin, 1983

(In thousand cubic feet)

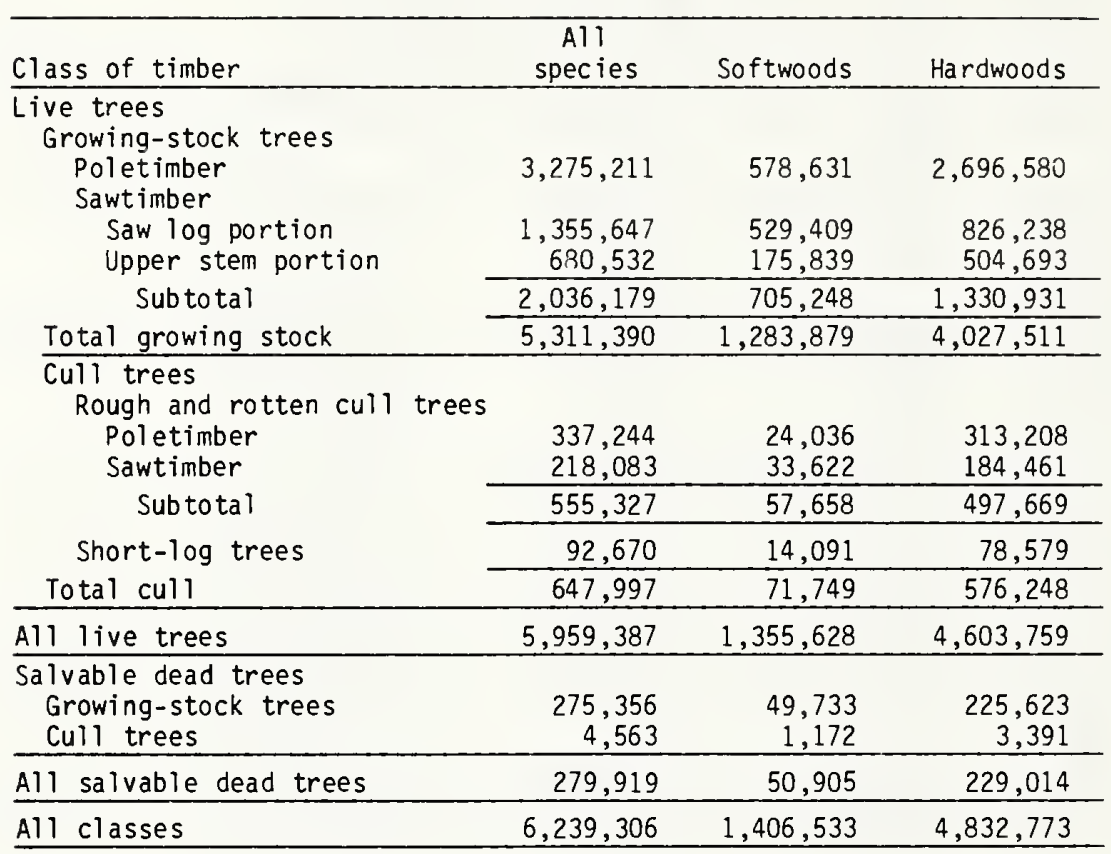




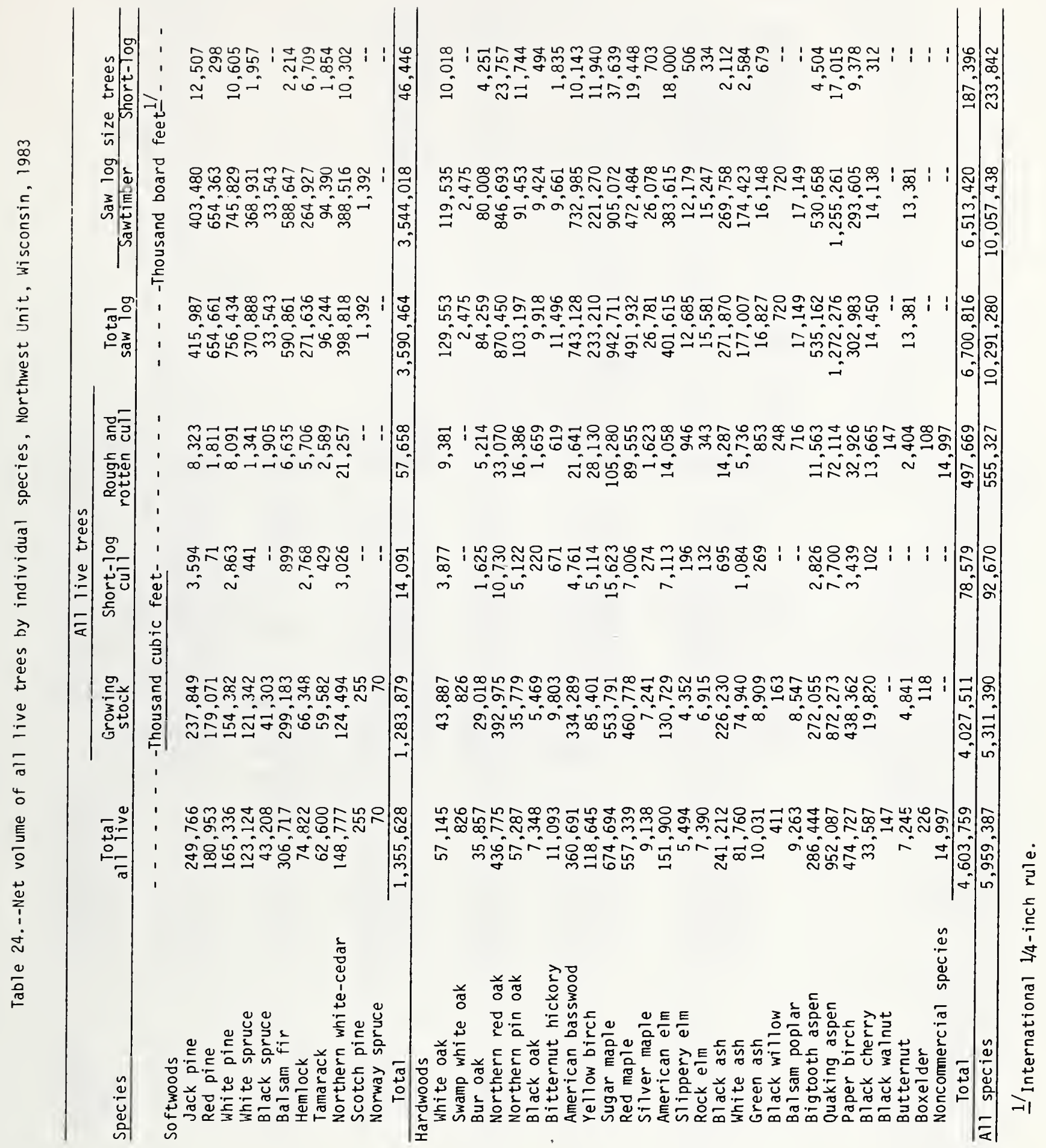


Table 25.--Net volume of noncommercial species on commercial forest 1 and by individual species,

Northwest Unit, Wisconsin, 1983

(In thousand cubic feet)

\begin{tabular}{lr}
\hline Species & Cull volume \\
\hline American hornbeam & 223 \\
Eastern hophornbeam & 14,039 \\
Chokecherry & 231 \\
Mountain ash & 504 \\
\hline All species & 14,997 \\
\hline
\end{tabular}

Table 26.--Net volume of growing stock on commercial forest land by species group and county, Northwest Unit, Wisconsin, 1983

(In thousand cubic feet)

\begin{tabular}{|c|c|c|c|c|c|c|c|}
\hline \multirow[b]{2}{*}{ Species group } & \multirow{2}{*}{$\begin{array}{l}\text { All } \\
\text { counties }\end{array}$} & \multicolumn{6}{|c|}{ County } \\
\hline & & Ashl and & Barron & Bayfield & Burnett & Douglas & Iron \\
\hline \multicolumn{8}{|l|}{ Softwoods } \\
\hline Jack pine & 237,849 & 1,100 & 456 & 67,583 & 56,886 & 62,569 & \\
\hline Red pine & 179,071 & 17,833 & 257 & 53,262 & 14,505 & 12,871 & 6,102 \\
\hline White pine & 154,382 & 23,513 & 2,628 & 37,796 & 6,784 & 7,465 & 7,866 \\
\hline White spruce & 121,342 & 41,820 & - & 11,297 & - & 12,831 & 12,126 \\
\hline Black spruce & 41,303 & 6,961 & 579 & 1,011 & 357 & 8,250 & 7,746 \\
\hline Balsam fir & 299,183 & 63,547 & -- & 34,691 & -- & 60,080 & 57,619 \\
\hline Hemlock & 66,348 & 12,573 & -- & 7,157 & -- & $i, 220$ & 17,168 \\
\hline Tamarack & 59,582 & 3,673 & 415 & 5,497 & 1,306 & 7,879 & 3,006 \\
\hline Northern white-cedar & 124,494 & 38,217 & -- & 13,299 & -- & 9,479 & 31,936 \\
\hline Other softwoods & 325 & -- & -- & -- & -- & -- & 70 \\
\hline Total & $1,283,879$ & 209,237 & 4,335 & 231,593 & 79,838 & 182,644 & 143,639 \\
\hline \multicolumn{8}{|l|}{ Hardwoods } \\
\hline White oak & 73,731 & 141 & 17,152 & 637 & 10,839 & 1,240 & -- \\
\hline Select red oak & 392,975 & 6,794 & 28,970 & 107,971 & 33,600 & 20,538 & 7,631 \\
\hline Other red oak & 41,248 & -- & 1,312 & 2,877 & 15,756 & 2,054 & - \\
\hline Select hickory & -- & -- & -- & -- & -- & -- & -- \\
\hline Other hickory & 9,803 & -- & 758 & -- & 542 & -- & -- \\
\hline Basswood & 334,289 & 39,820 & 7,701 & 26,580 & 5,821 & 15,337 & 29,609 \\
\hline Beech & & -- & -- & - & -- & -- & \\
\hline Yellow birch & 85,401 & 15,111 & 81 & 5,827 & 135 & 5,200 & 17,739 \\
\hline Hard maple & 553,791 & 124,845 & 4,502 & 72,378 & 4,106 & 27,163 & 80,295 \\
\hline Soft maple & 468,019 & 55,722 & 7,540 & 53,614 & 11,300 & 36,532 & 33,959 \\
\hline Elm & 141,996 & 20,076 & 6,425 & 10,954 & 6,777 & 8,107 & 15,159 \\
\hline Black ash & 226,230 & 24,910 & 3,391 & 17,401 & 10,717 & 40,194 & 13,714 \\
\hline White \& green ash & 83,849 & 6,408 & 6,260 & 4,983 & 1,575 & 2,293 & 3,950 \\
\hline Sycamore & -- & -- & -- & -- & -- & -- & -- \\
\hline Cottonwood & -- & -- & -- & -- & -- & -- & - \\
\hline Willow & 163 & -- & -- & -- & 163 & -- & -- \\
\hline Hackberry & & -- & -- & -- & -- & -- & - \\
\hline Balsam poplar & 8,547 & -- & -- & 2,272 & -- & 5,193 & 957 \\
\hline Bigtooth aspen & 272,055 & 14,604 & 14,454 & 72,999 & 26,716 & 11,830 & 9,053 \\
\hline Quaking aspen & 872,273 & 93,501 & 27,989 & 151,387 & 49,312 & 109,617 & 55,132 \\
\hline Paper birch & 438,362 & 35,944 & 12,523 & 94,786 & 19,277 & 77,957 & 29,867 \\
\hline Bl ack cherry & 19,820 & 3,912 & 619 & - & 1,708 & - & 3,099 \\
\hline Black walnut & -- & -- & -- & -- & -- & -- & -- \\
\hline Butternut & 4,841 & -- & 232 & -- & 394 & $\cdots$ & -- \\
\hline Other hardwoods & 118 & -- & -- & -- & -- & 118 & -- \\
\hline Total & $4,027,511$ & 441,788 & 139,909 & 624,666 & 198,738 & 363,373 & 300,164 \\
\hline All species & $5,311,390$ & 651,025 & 144,244 & 856,259 & 278,576 & 546,017 & 443,803 \\
\hline
\end{tabular}




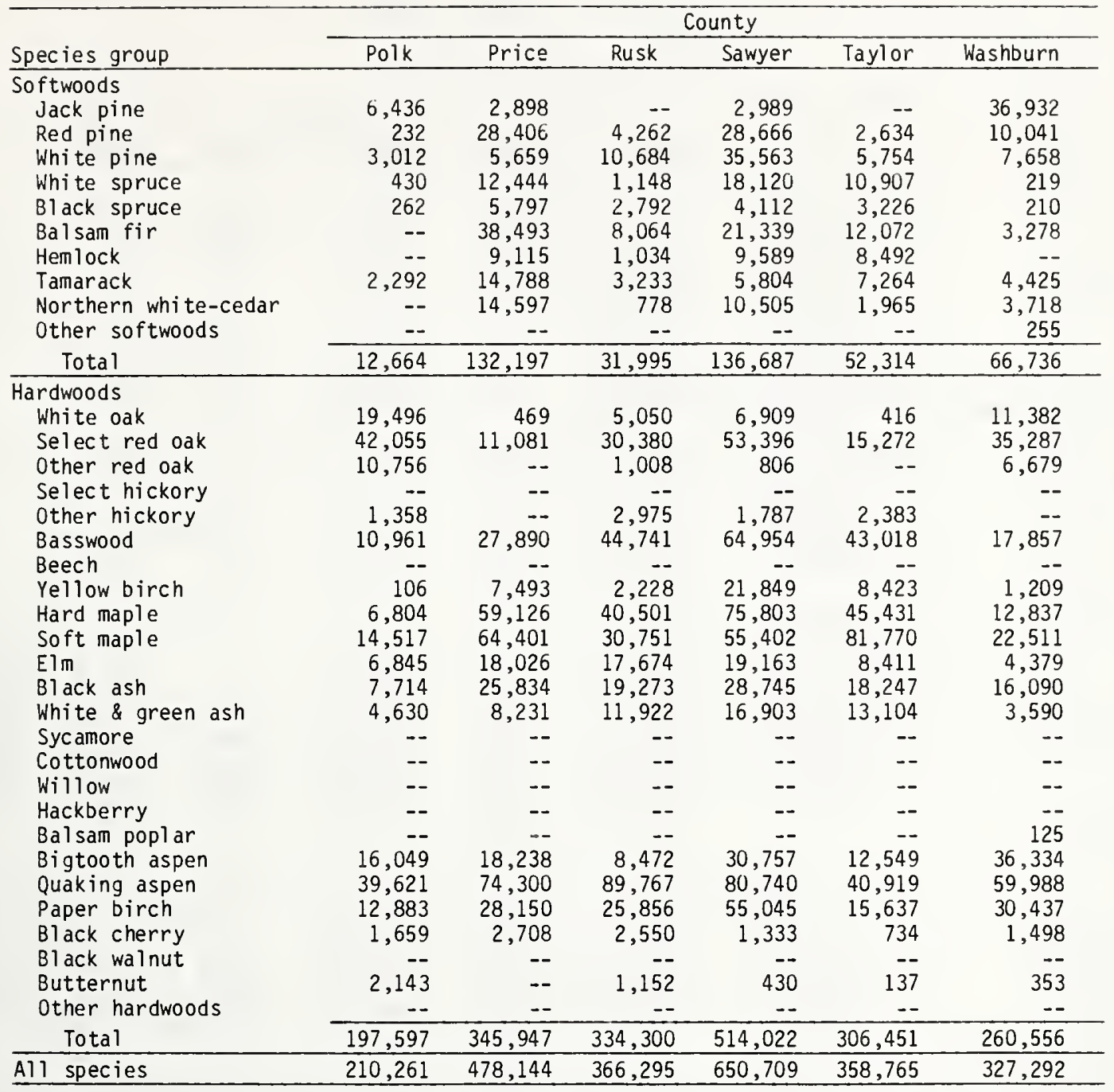


Table 27.--Net volume of sawtimber on commercial forest land by species group and county, Northwest Unit, Wisconsin, 1983

(In thousand board feet) $\underline{\text { I }}$

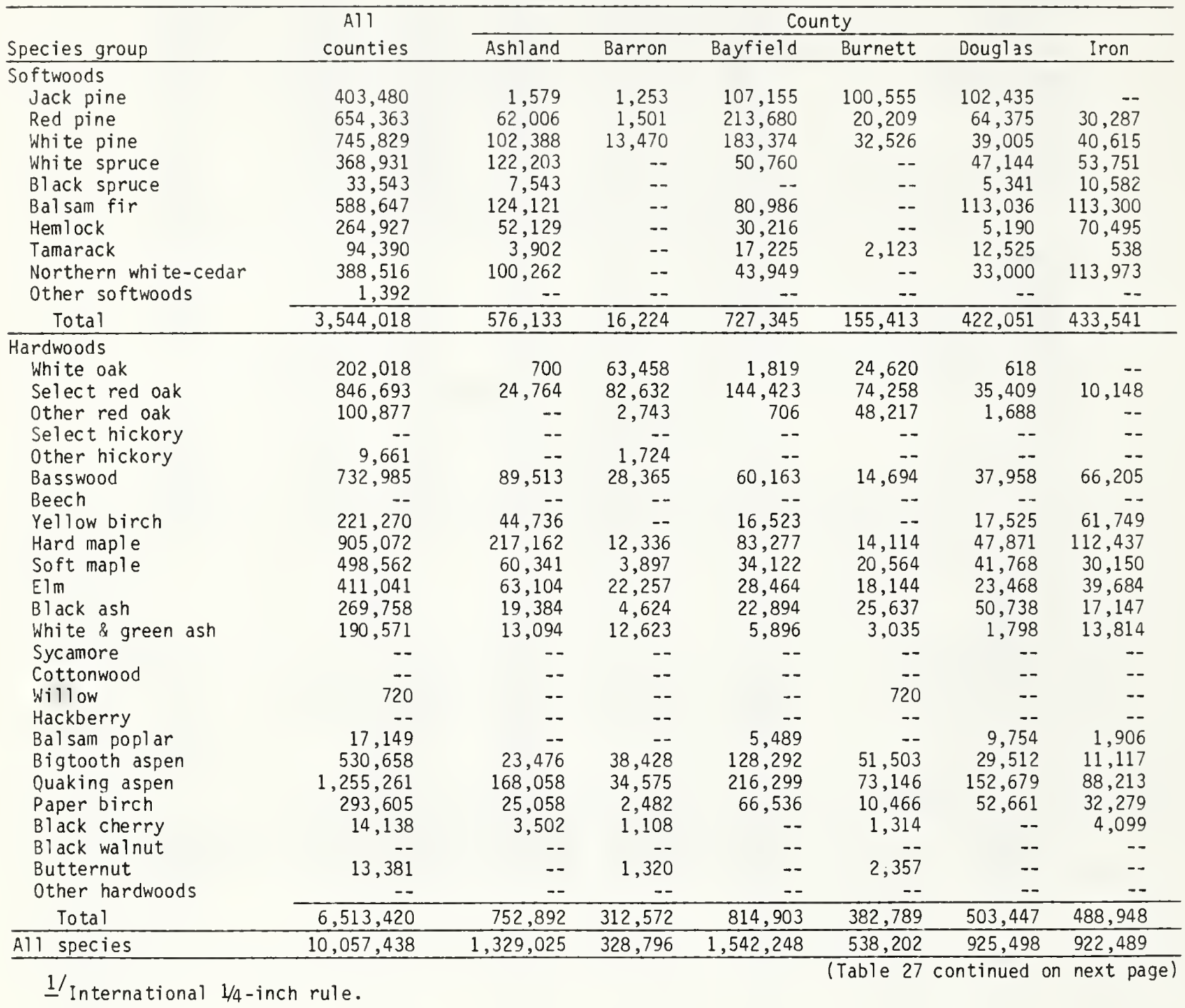




\begin{tabular}{|c|c|c|c|c|c|c|}
\hline \multirow[b]{2}{*}{ Species group } & \multicolumn{6}{|c|}{ County } \\
\hline & Polk & Price & Rusk & Sawyer & Taylor & Washburn \\
\hline \multicolumn{7}{|l|}{ Softwoods } \\
\hline Jack pine & 9,113 & 11,184 & -- & 9,449 & -- & 60,757 \\
\hline Red pine & 1,312 & 90,249 & 20,241 & 108,207 & 9,318 & 32,978 \\
\hline White pine & 16,995 & 28,960 & 53,965 & 171,614 & 26,413 & 36,504 \\
\hline White spruce & 2,347 & 35,982 & 5,178 & 26,548 & 23,875 & 1,143 \\
\hline Black spruce & -- & 2,495 & -- & 6,246 & 1,336 & - \\
\hline Balsam fir & -- & 72,749 & 16,989 & 37,764 & 21,508 & 8,194 \\
\hline Hemlock & -- & 38,075 & 3,374 & 38,944 & 26,504 & -- \\
\hline Tamarack & 5,737 & 20,912 & 4,099 & 6,471 & 11,134 & 9,724 \\
\hline Northern white-cedar & -- & 33,177 & 3,543 & 41,694 & 6,496 & 12,422 \\
\hline 0ther softwoods & -- & $-\cdots$ & - & -- & -- & 1,392 \\
\hline Total & 35,504 & 333,783 & 107,389 & 446,937 & 126,584 & 163,114 \\
\hline \multicolumn{7}{|l|}{ Hardwoods } \\
\hline White oak & 64,835 & 1,869 & 12,067 & 8,510 & 1,137 & 22,385 \\
\hline Select red oak & 115,949 & 12,190 & 96,480 & 135,497 & 47,402 & 67,541 \\
\hline other red oak & 34,078 & -- & 4,631 & 2,549 & -- & 6,265 \\
\hline Select hickory & -- & -- & -- & -- & $-\infty$ & - \\
\hline Other hickory & -- & -- & 3,598 & $=-$ & 4,339 & -- \\
\hline Basswood & 29,508 & 54,208 & 102,459 & 123,045 & 99,957 & 26,910 \\
\hline Beech & -- & -- & & -- & - & -- \\
\hline Yellow birch & -- & 20,491 & 1,863 & 39,626 & 14,005 & 4,752 \\
\hline Hard maple & 15,647 & 97,403 & 103,922 & 119,440 & 55,141 & 26,322 \\
\hline Soft maple & 15,950 & 67,789 & 32,370 & 76,605 & 88,823 & 26,183 \\
\hline Elm & 20,687 & 52,448 & 55,885 & 48,044 & 23,738 & 15,118 \\
\hline Black ash & 8,209 & 27,173 & 31,494 & 33,077 & 14,532 & 14,849 \\
\hline White \& green ash & 6,205 & 24,506 & 25,916 & 41,781 & 36,290 & 5,613 \\
\hline Sycamore & -- & -- & -- & -- & $-\infty$ & -- \\
\hline Cottonwood & -- & -- & -- & -- & -- & -- \\
\hline Willow & -- & -- & -- & -- & -- & -- \\
\hline Hackberry & -- & -- & -- & -- & -- & $\ldots$ \\
\hline Balsam poplar & -- & 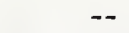 & -- & $=-$ & -- & -- \\
\hline Bigtooth aspen & 34,288 & 22,819 & 20,056 & 82,465 & 18,625 & 70,077 \\
\hline Quaking aspen & 44,271 & 114,047 & 121,632 & 139,002 & 25,466 & 77,873 \\
\hline Paper birch & 6,104 & 31,385 & 7,678 & 33,710 & 11,995 & 13,251 \\
\hline Bl ack cherry & -- & 2,041 & 1,382 & 692 & -- & - \\
\hline Black walnut & -- & -- & -- & -- & -- & -- \\
\hline Butternut & 2,718 & -- & 5,187 & -- & 743 & 1,056 \\
\hline Other hardwoods & -- & -- & - & -- & -- & -- \\
\hline Total & 398,449 & 528,369 & 626,620 & 884,043 & 442,193 & 378,195 \\
\hline All species & 433,953 & 862,152 & 734,009 & $1,330,980$ & 568,777 & 541,309 \\
\hline
\end{tabular}




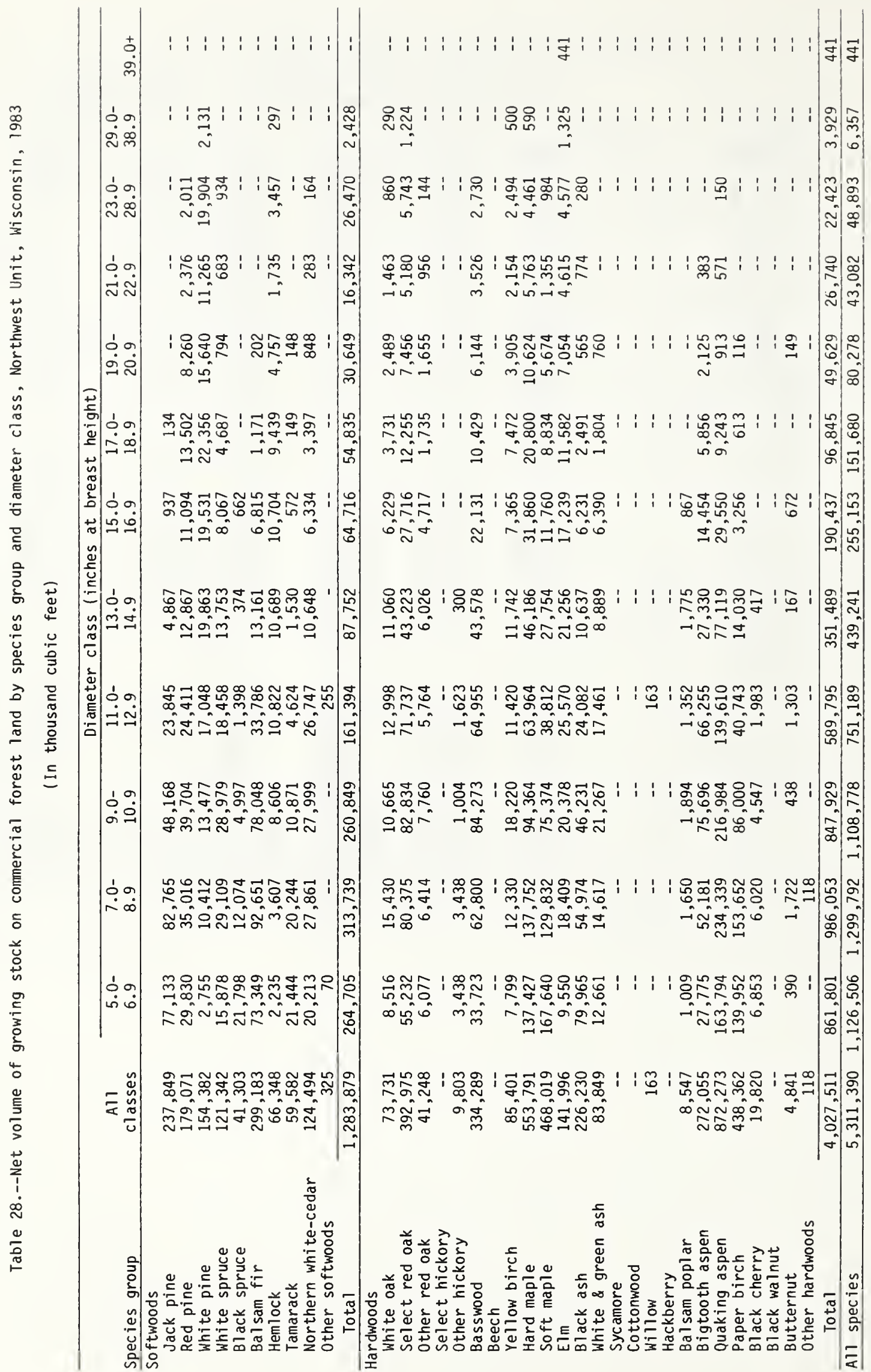




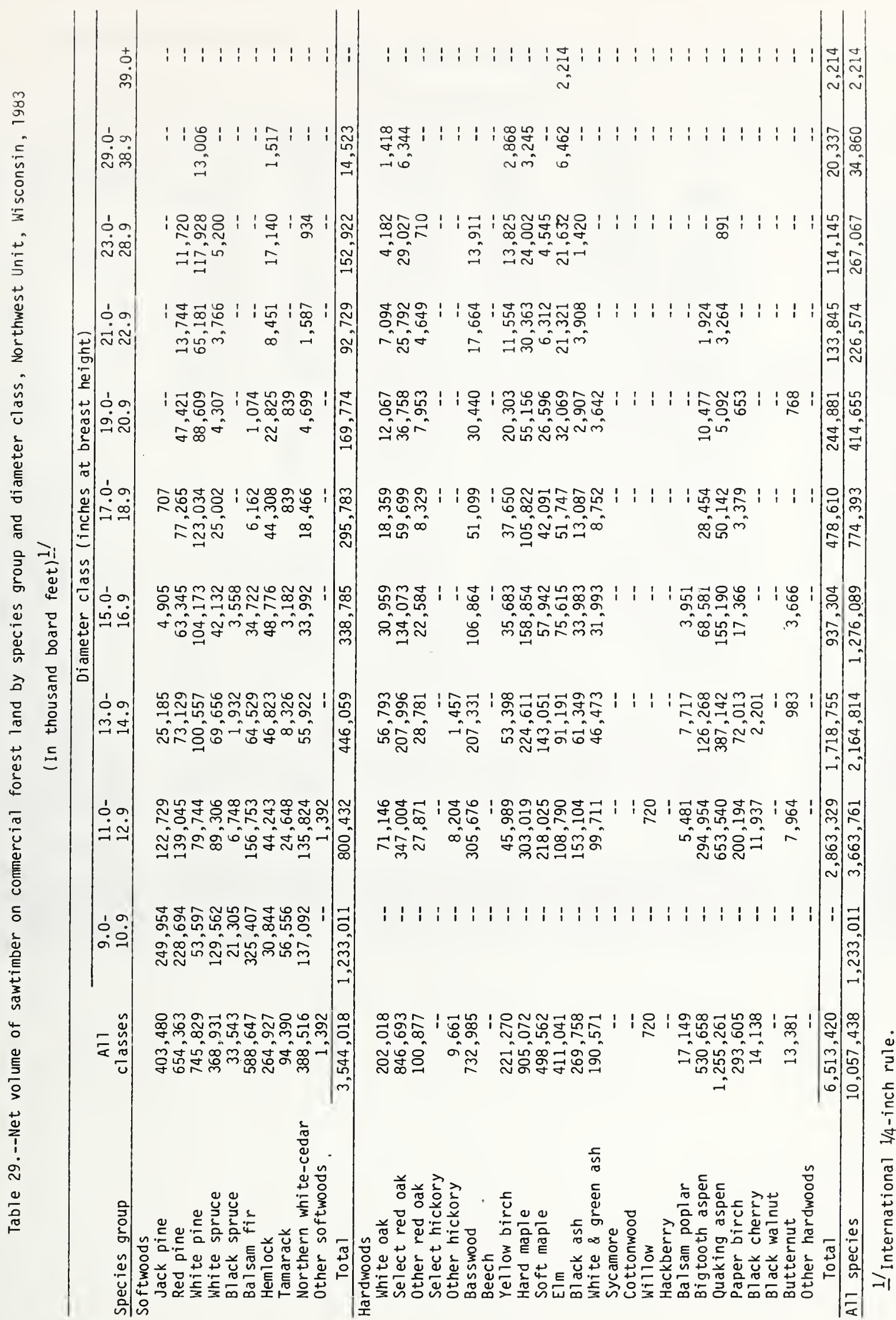


Table 30.--Net volume of growing stock on commercial forest land by species group and forest type, Northwest Unit, Wisconsin, 1983

(In thousand cubic feet)

\begin{tabular}{|c|c|c|c|c|c|c|c|c|}
\hline \multirow[b]{2}{*}{ Species group } & \multirow[b]{2}{*}{$\begin{array}{l}\text { All } \\
\text { types }\end{array}$} & \multicolumn{7}{|c|}{ Forest type } \\
\hline & & $\begin{array}{l}\text { Jack } \\
\text { pine }\end{array}$ & $\begin{array}{l}\text { Red } \\
\text { pine }\end{array}$ & $\begin{array}{l}\text { White } \\
\text { pine }\end{array}$ & $\begin{array}{l}\text { Bal sam } \\
\text { fir }\end{array}$ & $\begin{array}{l}\text { White } \\
\text { spruce }\end{array}$ & $\begin{array}{l}\text { Black } \\
\text { spruce }\end{array}$ & $\begin{array}{l}\text { Northern } \\
\text { white- } \\
\text { cedar }\end{array}$ \\
\hline \multicolumn{9}{|l|}{ so: twoods } \\
\hline White pine & $\begin{array}{l}17 y, 071 \\
154,382\end{array}$ & $\begin{array}{l}0,041 \\
2,268\end{array}$ & 22,692 & $\begin{array}{r}9,104 \\
40,448\end{array}$ & $\begin{array}{l}2,345 \\
7,352\end{array}$ & 1,753 & $\begin{array}{r}888 \\
1,070\end{array}$ & 843 \\
\hline White spruce & 121,342 & -- & 994 & 2,249 & 12,982 & 62,477 & 641 & 2,398 \\
\hline Black spruce & 41,303 & 201 & -. & 715 & 4,928 & 367 & 16,194 & 4,200 \\
\hline Balsam fir & 299,183 & 80 & 1,736 & 2,234 & 107,449 & 2,080 & 2,337 & 12,806 \\
\hline Heml ock & 66,348 & -- & -- & -- & 1,649 & -- & 1,287 & 3,930 \\
\hline Tamarack & 59,582 & -- & -- & 735 & 3,360 & -- & 6,945 & 3,633 \\
\hline Northern white-cedar & 124,494 & -- & 434 & -- & 19,044 & 1,036 & 3,080 & 68,665 \\
\hline Other sof twoods & 325 & -- & -- & 255 & -- & -- & -- & -- \\
\hline Total & $1,283,879$ & 199,356 & 151,959 & 57,046 & 159,109 & 67,844 & 32,442 & 96,475 \\
\hline \multicolumn{9}{|l|}{ Hardwoods } \\
\hline White oak & 73,731 & -- & -- & 254 & 77 & -- & 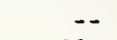 & -- \\
\hline Select red oak & 392,975 & 2,289 & 4,356 & 607 & 239 & -- & 430 & -- \\
\hline Other red oak & 41,248 & 2,988 & -- & 258 & - & -- & 75 & -- \\
\hline Select hickory & & -- & -- & -- & -- & -- & -- & -- \\
\hline Other hickory & 9,803 & -- & -- & -- & -- & -- & -- & -- \\
\hline Basswood & 334,289 & -- & -- & 421 & -- & -- & -- & -- \\
\hline Beech & -- & -- & -- & -- & -- & -- & $-\overline{-}$ & -- \\
\hline Yellow birch & 85,401 & -- & -- & -- & 2,985 & -- & 173 & 5,307 \\
\hline Hard maple & 553,791 & -- & 666 & -- & 1,429 & 118 & 107 & -- \\
\hline Soft maple & 468,019 & - & 4,038 & 1,248 & 6,298 & 688 & 781 & 2,235 \\
\hline Elm & 141,996 & -- & 102 & 251 & 1,382 & -- & -- & -- \\
\hline Black ash & 226,230 & -- & -- & -- & 9,017 & 174 & -- & 6,081 \\
\hline White \& green ash & 83,849 & -- & 118 & -- & 116 & 536 & -. & -- \\
\hline Sycamore & -- & -- & -- & -- & -- & -- & -- & $\cdots$ \\
\hline Cottonwood & -- & -- & -- & -- & -- & -- & -- & -- \\
\hline Willow & 163 & -- & -- & - & -- & -- & -- & -- \\
\hline Hackberry & $\ddot{z}$ & -- & -- & -- & -- & -- & -- & -- \\
\hline Balsam poplar & 8,547 & -- & - & -- & 110 & - & $\ldots$ & -- \\
\hline Bigtooth aspen & 272,055 & 1,761 & 1,985 & 1,440 & 462 & 185 & 191 & 223 \\
\hline Quaking aspen & 872,273 & 6,075 & 7,169 & 9,194 & 18,317 & 1,339 & 1,816 & 1,841 \\
\hline Paper birch & 438,362 & 492 & 3,168 & 1,440 & 10,301 & 522 & 1,359 & 3,167 \\
\hline Black cherry & 19,820 & -- & -- & -- & 102 & - & -- & -- \\
\hline Black walnut & & -- & -- & -- & -- & -- & $\cdots$ & -- \\
\hline Butternut & 4,841 & $=$ & -- & -- & -- & -- & -- & -- \\
\hline other hardwoods & 1.18 & $-\cdot$ & -- & $\cdots$ & -- & -- & -- & $\cdots$ \\
\hline Total & $4,027,511$ & 13,605 & 21,602 & 15,113 & 50,835 & 3,562 & 4,932 & 18,854 \\
\hline All species & $5,311,390$ & 212,961 & 173,561 & 72,159 & 209,944 & 71,406 & 37,374 & 115,329 \\
\hline
\end{tabular}




\begin{tabular}{|c|c|c|c|c|c|c|c|c|}
\hline \multirow[b]{2}{*}{ Species group } & \multicolumn{8}{|c|}{ Forest type } \\
\hline & Tamarack & $\begin{array}{c}\text { Oak- } \\
\text { hickory }\end{array}$ & $\begin{array}{c}\text { Elm-ash- } \\
\text { soft maple }\end{array}$ & $\begin{array}{l}\text { Maple- } \\
\text { birch }\end{array}$ & Aspen & $\begin{array}{l}\text { Paper } \\
\text { birch }\end{array}$ & Exotic & $\begin{array}{c}\text { Non- } \\
\text { stocked }\end{array}$ \\
\hline \multicolumn{9}{|l|}{ Softwoods } \\
\hline Jack pine & 331 & 26,701 & 345 & 573 & 14,798 & 1,574 & -- & 1,098 \\
\hline Red pine & 304 & 5,019 & 256 & 5,633 & 20,992 & 2,612 & -- & -- \\
\hline White pine & 3,782 & 7,299 & 6,382 & 32,842 & 23,257 & 4,312 & -- & 82 \\
\hline White spruce & 381 & -- & 3,592 & 12,736 & 16,638 & 6,053 & -- & 201 \\
\hline Black spruce & 5,338 & -- & 1,521 & 936 & 4,991 & 1,912 & -- & -- \\
\hline Balsam fir & 5,075 & 681 & 31,462 & 62,340 & 53,250 & 17,653 & -- & -- \\
\hline Hemlock & 79 & 594 & 4,448 & 50,823 & 1,982 & 1,556 & -- & -- \\
\hline Tamarack & 30,826 & 141 & 4,612 & 1,108 & 6,230 & 1,372 & -- & 620 \\
\hline Northern white-cedar & 369 & -- & 12,350 & 15,447 & 3,141 & 928 & -- & -- \\
\hline Other softwoods & -- & -- & -- & 70 & -- & -- & -- & -- \\
\hline Total & 46,485 & 40,435 & 64,968 & 182,508 & 145,279 & 37,972 & -- & 2,001 \\
\hline \multicolumn{9}{|l|}{ Hardwoods } \\
\hline White oak & -- & 36,918 & 4,220 & 14,644 & 15,199 & 2,247 & -- & 172 \\
\hline Select red oak & -- & 191,524 & 5,295 & 110,239 & 59,684 & 18,312 & -- & -- \\
\hline other red oak & -- & 25,533 & 1,073 & 2,947 & 7,118 & 1,110 & -- & 146 \\
\hline Select hickory & -- & - & -- & -- & -- & -- & -- & -- \\
\hline Other hickory & -- & 1,209 & 231 & 8,015 & 348 & -- & - & -- \\
\hline Basswood & -- & 10,738 & 11,747 & 295,218 & 12,531 & 3,634 & -- & -- \\
\hline Beech & -- & -- & -- & -- & -- & -- & -- & -- \\
\hline yellow birch & 135 & 81 & 8,411 & 65,440 & 2,147 & 722 & -- & -- \\
\hline Hard maple & 105 & 7,610 & 10,304 & 512,290 & 14,724 & 6,337 & - & 101 \\
\hline Soft maple & 2,081 & 18,090 & 68,843 & 267,862 & 74,626 & 21,118 & -- & 111 \\
\hline Elm & -- & 4,198 & 35,520 & 88,646 & 9,905 & 1,992 & -- & -- \\
\hline Black ash & -- & 2,542 & 128,134 & 60,272 & 15,452 & 4,139 & -- & 419 \\
\hline White \& green ash & -- & 4,708 & 6,120 & 65,671 & 3,796 & 2,784 & -- & -- \\
\hline Sycamore & -- & -- & -- & -- & -- & -- & -- & -- \\
\hline Cottonwood & -- & -- & -- & -- & -- & -- & -- & -- \\
\hline Willow & -- & -- & 163 & -- & -- & -- & -- & -- \\
\hline Hackberry & -- & -- & - & -- & -- & - & -- & -- \\
\hline Bal sam poplar & -- & 109 & 807 & 287 & 6,911 & 323 & -- & -- \\
\hline Bigtooth aspen & 2,249 & 31,403 & 1,732 & 30,499 & 187,996 & 11,929 & -- & -- \\
\hline Quaking aspen & 2,729 & 16,105 & 26,025 & 122,947 & 621,962 & 34,658 & -- & 2,096 \\
\hline Paper birch & 1,876 & 29,568 & 12,392 & 86,479 & 131,887 & 154,923 & -- & 788 \\
\hline Bl ack cherry & -- & 1,459 & 132 & 11,261 & 5,853 & 1,013 & -- & -- \\
\hline Bl ack walnut & -- & -- & -- & -- & -- & -- & -- & -- \\
\hline Butternut & -- & 1,163 & -- & 3,678 & -- & -- & -- & -- \\
\hline Other hardwoods & -- & - & 118 & - & - & -- & -- & -- \\
\hline Total & 9,175 & 382,958 & 321,267 & $1,746,395$ & $1,170,139$ & 265,241 & -- & 3,833 \\
\hline All species & 55,660 & 423,393 & 386,235 & $1,928,903$ & $1,315,418$ & 303,213 & -- & 5,834 \\
\hline
\end{tabular}


Table 31.--Net volume of sawtimber on commercial forest land by species group and forest type, Northwest Unit, Wisconsin, 1983

(In thousand board feet) 1 !

\begin{tabular}{|c|c|c|c|c|c|c|c|c|}
\hline \multirow[b]{2}{*}{ Species group } & \multirow[b]{2}{*}{$\begin{array}{l}\text { Al } 1 \\
\text { types }\end{array}$} & \multicolumn{7}{|c|}{ Forest type } \\
\hline & & $\begin{array}{l}\text { Jack } \\
\text { pine }\end{array}$ & $\begin{array}{l}\text { Red } \\
\text { pine } \\
\end{array}$ & $\begin{array}{l}\text { Whi te } \\
\text { pine }\end{array}$ & $\begin{array}{l}\text { Balsam } \\
\text { fir }\end{array}$ & $\begin{array}{l}\text { White } \\
\text { spruce }\end{array}$ & $\begin{array}{l}\text { Black } \\
\text { spruce }\end{array}$ & $\begin{array}{c}\text { Northern } \\
\text { white- } \\
\text { cedar } \\
\end{array}$ \\
\hline \multicolumn{9}{|l|}{ Sof twoods } \\
\hline $\begin{array}{l}\text { Jack pine } \\
\text { Red pine }\end{array}$ & 403,480 & & & 3,593 & - & -- & $\overline{--}$ & -- \\
\hline $\begin{array}{l}\text { Red pine } \\
\text { White pine }\end{array}$ & $\begin{array}{l}654,363 \\
745,829\end{array}$ & $\begin{array}{l}37,574 \\
10,136\end{array}$ & $\begin{array}{l}394,811 \\
102,375\end{array}$ & $\begin{array}{r}40,923 \\
182,169\end{array}$ & 11,212 & a & 5,136 & $-\overline{-}$ \\
\hline $\begin{array}{l}\text { White pine } \\
\text { White spruce }\end{array}$ & $\begin{array}{l}745,829 \\
368,931\end{array}$ & $\begin{array}{r}10,136 \\
--\end{array}$ & $\begin{array}{r}102,315 \\
4,116\end{array}$ & $\begin{array}{r}182,169 \\
10,243\end{array}$ & 36,804 & $\begin{array}{r}9,288 \\
140,169\end{array}$ & 3,585 & 4,042 \\
\hline Black spruce & $\begin{array}{r}308,931 \\
33,543\end{array}$ & -- & & $\begin{array}{r}10,243 \\
--\end{array}$ & $\begin{array}{r}48,556 \\
7,861\end{array}$ & $\begin{array}{r}140,109 \\
767\end{array}$ & $\begin{array}{l}2,603 \\
7,432\end{array}$ & 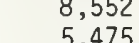 \\
\hline Balsam fir & 588,647 & -- & 4,160 & 9,119 & 208,532 & 3,640 & $\begin{array}{l}1,432 \\
3,457\end{array}$ & $\begin{array}{l}5,4 / 5 \\
5,815\end{array}$ \\
\hline Heml ock & 264,927 & -- & -- & -- & 5,510 & -- & 5,191 & 14,600 \\
\hline Tamarack & 94,390 & -- & -- & 840 & 6,750 & -- & 3,019 & 5,499 \\
\hline Northern white-cedar & 388,516 & -- & 1,134 & -- & 60,358 & -- & 8,825 & 203,009 \\
\hline Other so f twoods & 1,392 & -- & -- & 1,392 & -- & -- & - & -- \\
\hline Total & $3,544,018$ & 320,046 & 518,159 & 248,279 & 385,583 & 153,864 & 39,248 & 246,992 \\
\hline \multicolumn{9}{|l|}{ Hardwoods } \\
\hline White oak & 202,018 & -- & -- & 678 & -- & -- & -- & -- \\
\hline Select red oak & 846,693 & 2,766 & 4,555 & -- & 1,205 & -- & 596 & -- \\
\hline Other red oak & 100,877 & 6,269 & -- & 810 & -- & -- & 411 & -- \\
\hline Select hickory & -- & -- & -- & -- & -- & -- & -- & -- \\
\hline Other hickory & 9,661 & -- & -- & -- & -- & -- & -- & -- \\
\hline Basswood & 732,985 & -- & -- & 853 & -- & -- & -- & -- \\
\hline Beech & -- & -- & -- & -- & -- & -- & -- & -- \\
\hline Yellow birch & 221,270 & -- & -- & -- & 9,037 & -- & 481 & 18,603 \\
\hline Hard maple & 905,072 & -- & -- & -- & 2,380 & -- & -- & -- \\
\hline Soft maple & 498,562 & -- & -- & -- & 6,722 & 2,016 & -- & 3,077 \\
\hline Elm & 411,041 & -- & -- & 737 & 4,231 & -- & -- & -- \\
\hline Black ash & 269,758 & -- & -- & -- & 5,887 & 1,011 & -- & 759 \\
\hline White \& green ash & 190,571 & -- & -- & -- & -- & -- & -- & -- \\
\hline Sycamore & - & -- & -- & -- & -- & -- & -- & -- \\
\hline Cottonwood & -- & -- & -- & -- & -- & -- & -- & -- \\
\hline Willow & 720 & -- & -- & -- & -- & -- & -- & -- \\
\hline Hackberry & -- & -- & -- & -- & -- & -- & -- & -- \\
\hline Bal sam poplar & 17,149 & -- & -- & -- & -- & -- & -- & -- \\
\hline Bigtooth aspen & 530,658 & -- & 2,246 & 3,252 & -- & - & 977 & 565 \\
\hline Quaking aspen & $1,255,261$ & 2,433 & 7,317 & 16,051 & 34,604 & 4,554 & 3,788 & 3,761 \\
\hline Paper birch & 293,605 & -- & 4,425 & 687 & 10,342 & -- & 590 & 5,138 \\
\hline Black cherry & 14,138 & -- & -- & -- & 692 & -- & -- & -- \\
\hline Black walnut & & -- & -- & -- & -- & -- & -- & -- \\
\hline Butternut & 13,381 & -- & -- & -- & -- & -- & -- & -- \\
\hline Other hardwoods & & -- & -- & -- & -- & -- & -- & -- \\
\hline Total & $6,513,420$ & 11,468 & 18,543 & 23,068 & 75,100 & 7,581 & 6,843 & 31,903 \\
\hline All species & $10,057,438$ & 331,514 & 536,702 & 271,347 & 460,683 & 161,445 & 46,091 & 278,895 \\
\hline
\end{tabular}

1/International $1 / 4$-inch rule. 


\begin{tabular}{|c|c|c|c|c|c|c|c|c|}
\hline \multirow[b]{2}{*}{ Species group } & \multicolumn{8}{|c|}{ Forest type } \\
\hline & Tamarack & $\begin{array}{c}\text { 0ak- } \\
\text { hickory }\end{array}$ & $\begin{array}{l}\text { Elm-ash- } \\
\text { soft maple }\end{array}$ & $\begin{array}{l}\text { Maple- } \\
\text { birch }\end{array}$ & Aspen & $\begin{array}{l}\text { Paper } \\
\text { birch }\end{array}$ & Exotic & $\begin{array}{c}\text { Non- } \\
\text { stocked }\end{array}$ \\
\hline \multicolumn{9}{|l|}{ So ftwo ods } \\
\hline Jack pine & -- & 73,548 & 972 & 2,572 & 31,237 & 6,875 & -- & 784 \\
\hline Red pine & 1,734 & 17,203 & 1,465 & 32,380 & 97,764 & 14,161 & -- &.- \\
\hline White pine & 18,274 & 37,671 & 33,252 & 172,600 & 113,257 & 22,051 & -- & 325 \\
\hline White spruce & 909 & -- & 14,693 & 59,917 & 55,376 & 22,736 & -- & 1,061 \\
\hline Black spruce & 2,436 & -- & 4,736 & 2,551 & 1,512 & 773 & -- & -- \\
\hline Balsam fir & 1,441 & 556 & 66,716 & 152,060 & 96,169 & 36,982 & -- & -- \\
\hline Hemlock & 339 & 2,751 & 15,295 & 206,335 & 8,590 & 6,316 & -- & -- \\
\hline Tamarack & 34,199 & -- & 19,788 & 1,548 & 18,406 & 2,644 & -- & 1,697 \\
\hline Northern white-cedar & -- & -- & 45,066 & 58,188 & 9,850 & 2,086 & - & -- \\
\hline Other softwoods & -- & -- & -- & -- & -- & -- & -- & -- \\
\hline Total & 59,332 & 131,729 & 201,983 & 688,151 & 432,161 & 114,624 & -- & 3,867 \\
\hline \multicolumn{9}{|l|}{ Hardwoods } \\
\hline White oak & -- & 110,666 & 14,223 & 44,958 & 25,718 & 5,263 & -- & 512 \\
\hline Select red oak & -- & 370,967 & 16,823 & 335,228 & 79,185 & 35,368 & -- & -- \\
\hline Other red oak & -- & 51,882 & 4,187 & 12,685 & 20,591 & 3,296 & -- & 746 \\
\hline Select hickory & -- & - & -- & -- & -- & - & -- & -- \\
\hline other hickory & -- & 698 & -- & 8,963 & -- & -- & -- & -- \\
\hline Basswood & -- & 22,882 & 26,806 & 664,372 & 12,568 & 5,504 & -- & -- \\
\hline Beech & -- & -- & $-\infty$ & -- & -- & -- & -- & - \\
\hline Yellow birch & 629 & -- & 21,561 & 168,342 & 867 & 1,750 & -- & -- \\
\hline Hard maple & - & 11,539 & 6,952 & 869,626 & 8,972 & 5,603 & -- & -- \\
\hline Soft maple & 1,903 & 14,238 & 124,118 & 325,361 & 17,405 & 3,722 & -- & -- \\
\hline Elm & - & 13,652 & 103,795 & 264,062 & 18,724 & 5,840 & -- & -- \\
\hline Black ash & -- & 4,862 & 169,449 & 76,243 & 7,463 & 4,084 & -- & -- \\
\hline White \& green ash & -- & 8,111 & 16,533 & 160,296 & 2,214 & 3,417 & -- & -- \\
\hline Syc amore & -- & -- & $=-$ & -- & -- & -- & -- & -- \\
\hline Cottonwood & -- & -- & -- & -- & -- & -- & -- & -- \\
\hline Willow & -- & -- & 720 & -- & -- & -- & -- & -- \\
\hline Hackberry & -- & -- & -- & -- & -- & -- & -- & -- \\
\hline Balsam poplar & -- & -- & 2,045 & -- & 14,342 & 762 & -- & -- \\
\hline Bigtooth aspen & -- & 67,812 & 4,941 & 71,166 & 347,031 & 32,668 & -- & -- \\
\hline Quaking aspen & 1,292 & 24,402 & 40,872 & 288,712 & 766,624 & 59,524 & -- & 1,327 \\
\hline Paper birch & 2,054 & 11,758 & 12,870 & 87,720 & 75,019 & 83,002 & -- & -- \\
\hline Black cherry & -- & -- & -- & 10,750 & 1,314 & 1,382 & -- & -- \\
\hline Black walnut & - & -- & -- & -- & -- & -- & -- & -- \\
\hline Butternut & -- & 5,034 & -- & 8,347 & -- & -- & -- & -- \\
\hline Other hardwoods & -- & -- & -- & -- & -- & -- & $\rightarrow$ & -- \\
\hline Total & 5,878 & 718,503 & 565,895 & $3,396,831$ & $1,398,037$ & 251,185 & -- & 2,585 \\
\hline All species & 65,210 & 850,232 & 767,878 & $4,084,982$ & $1,830,198$ & 365,809 & -- & 6,452 \\
\hline
\end{tabular}




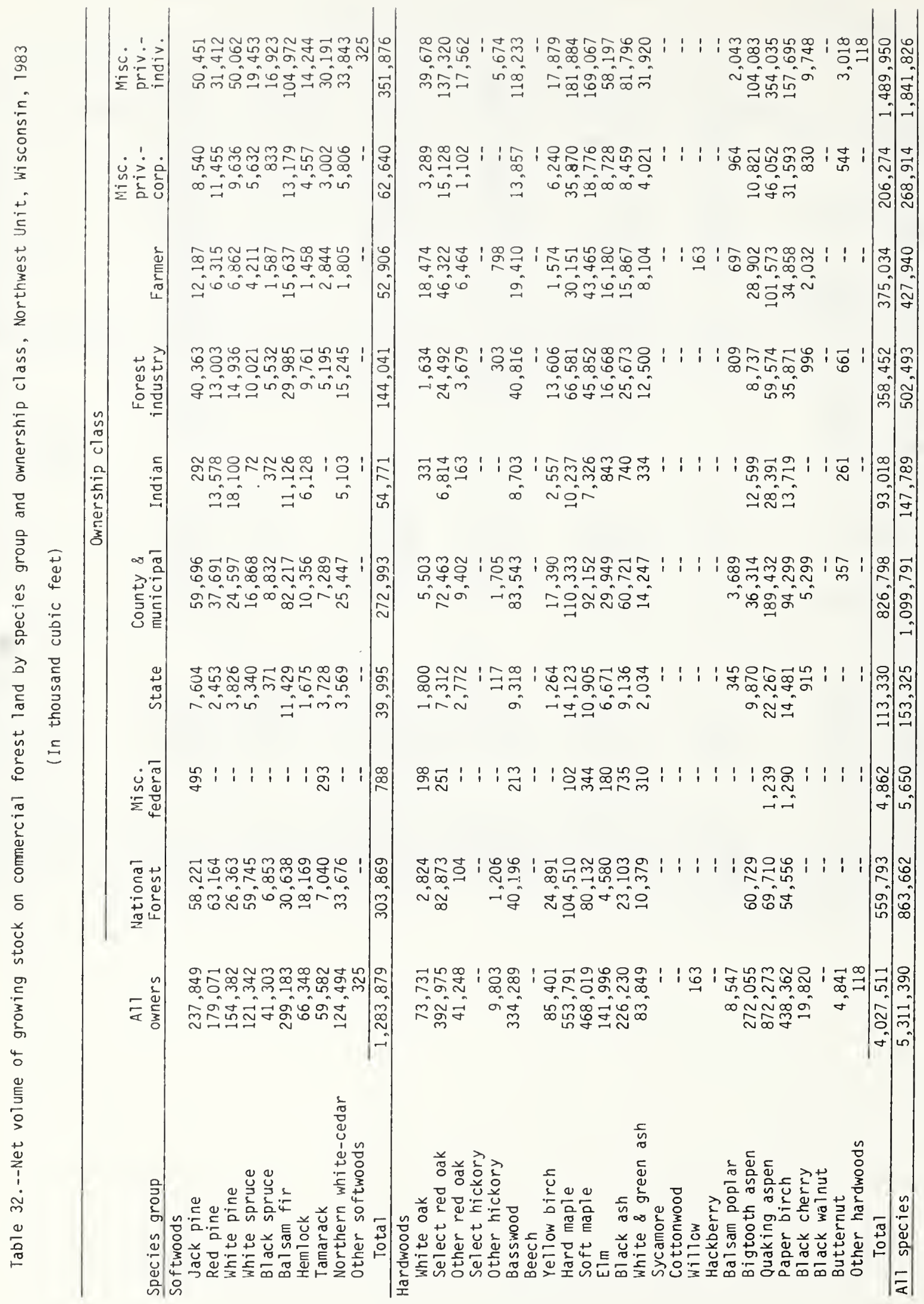




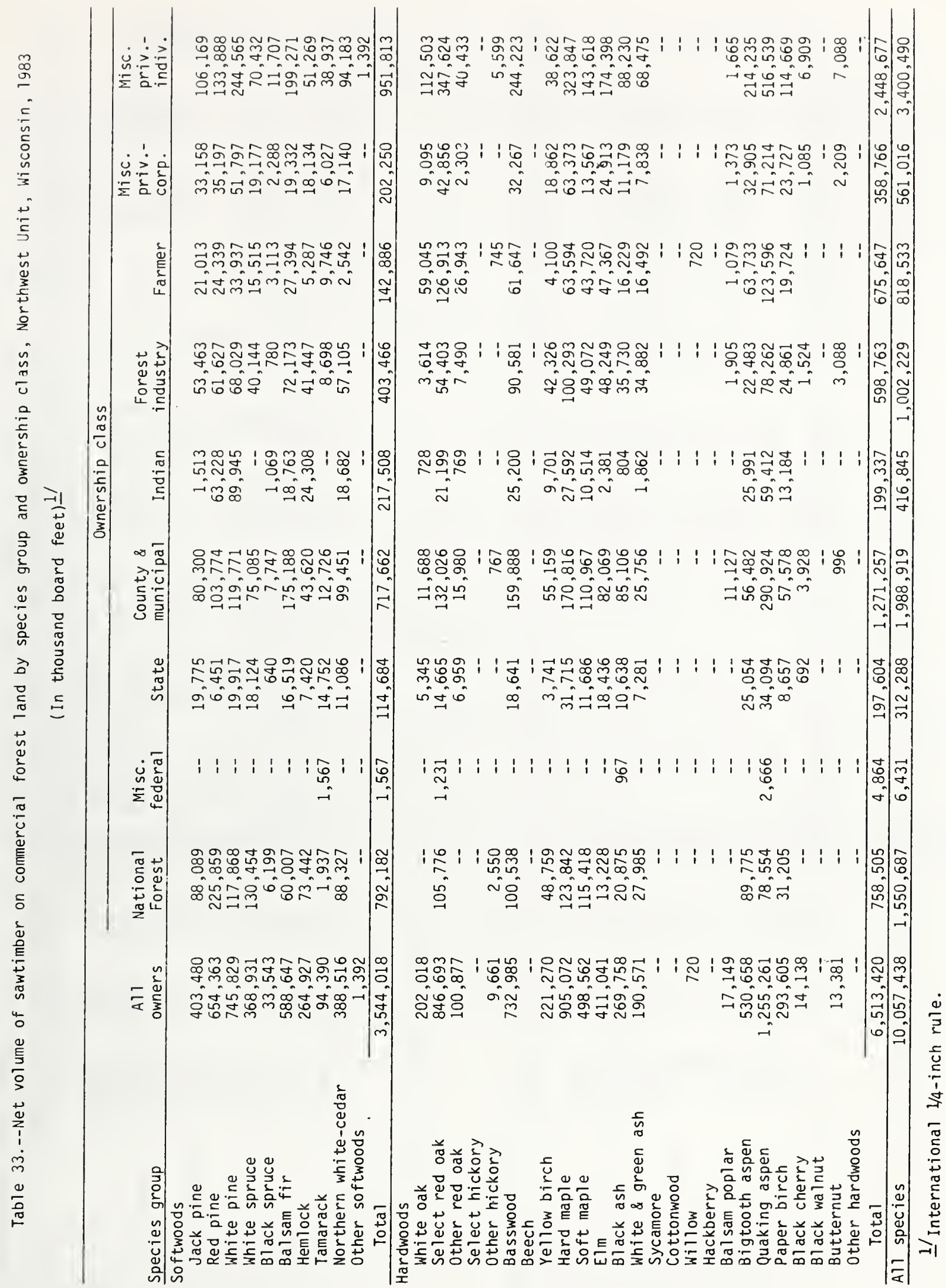



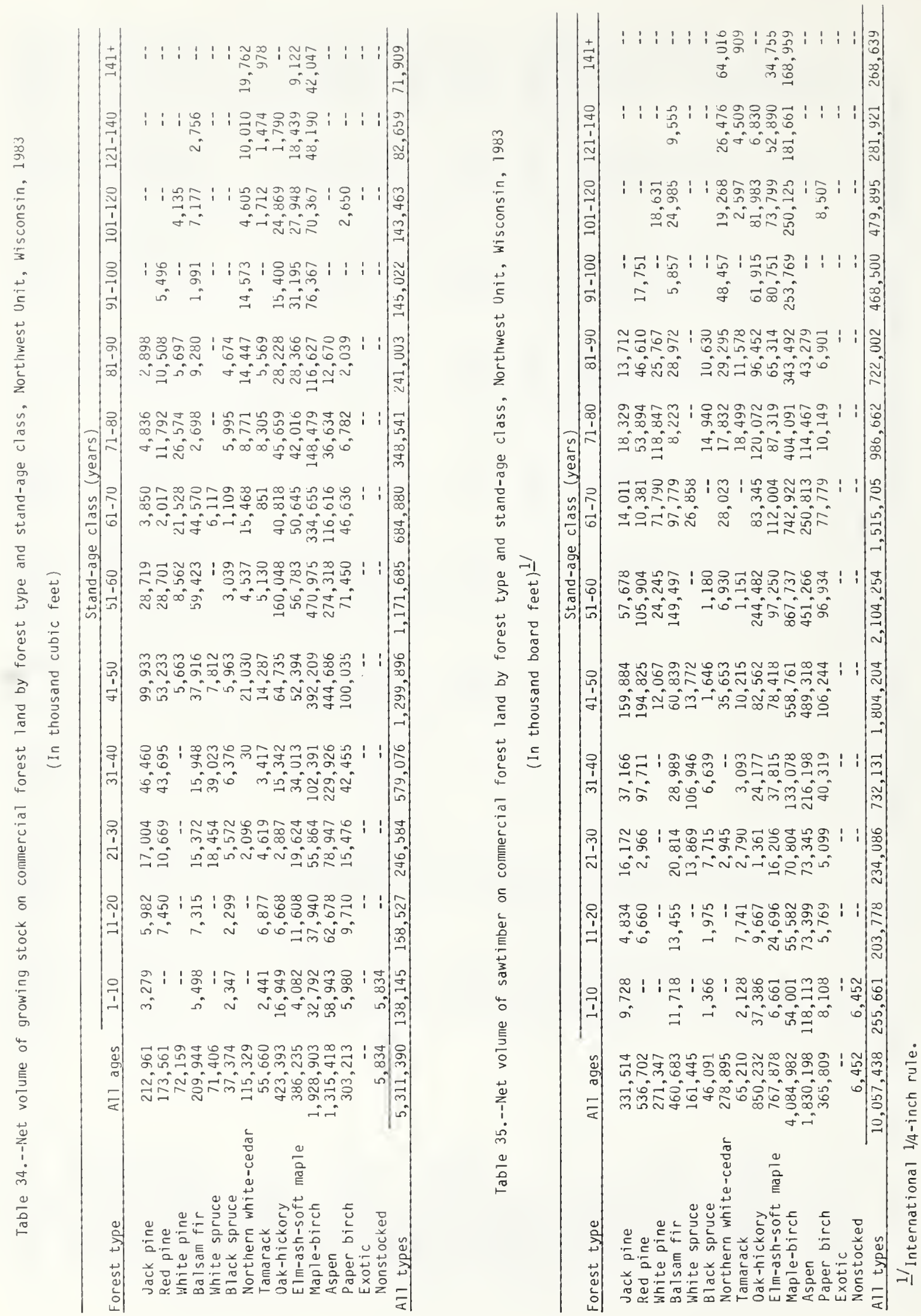
Table 36.--Net volume of growing stock on commercial forest land by forest type, stand-size class, and basal-area class, Northwest Unit, Wisconsin, 1983

(In thousand cubic feet)

\begin{tabular}{|c|c|c|c|c|c|c|c|c|}
\hline \multirow{2}{*}{$\begin{array}{l}\text { Forest type and } \\
\text { stand-size class }\end{array}$} & \multirow{2}{*}{$\begin{array}{c}\text { All } \\
\text { classes }\end{array}$} & \multicolumn{7}{|c|}{ Basal-area class (square feet per acre) } \\
\hline & & $0-10$ & $11-20$ & $21-30$ & $31-40$ & $41-50$ & $51-60$ & $61-70$ \\
\hline \multirow{5}{*}{$\begin{array}{l}\text { Jack pine } \\
\text { Sawtimber } \\
\text { Poletimber } \\
\text { Sapl ing \& seedling } \\
\text { All stands }\end{array}$} & & & & & & & & \\
\hline & 41,543 & -- & -- & -- & 786 & 877 & 1,738 & 4,630 \\
\hline & 155,658 & -- & -- & -- & 1,044 & 1,622 & 5,628 & 6,085 \\
\hline & 15,760 & 84 & -- & 1,095 & 1,878 & 1,401 & 2,002 & 206 \\
\hline & 212,961 & 84 & -- & 1,095 & 3,708 & 3,900 & 9,368 & 10,921 \\
\hline \multicolumn{9}{|l|}{ Red pine } \\
\hline Sawtimber & 119,795 & -- & -- & -- & 677 & 2,017 & 1,542 & -- \\
\hline Poletimber & 47,785 & -- & -- & -- & -- & -- & 1,389 & -- \\
\hline Sapling \& seedling & 5,981 & -- & -- & 243 & 1,043 & -- & 1,519 & -- \\
\hline All stands & 173,561 & -- & -- & 243 & 1,720 & 2,017 & 4,450 & -- \\
\hline \multicolumn{9}{|l|}{ White pine } \\
\hline Sawtimber & 63,856 & -- & -- & -- & 1,023 & -- & 895 & -- \\
\hline Poletimber & 8,303 & -- & -- & -- & -- & -- & -- & -- \\
\hline Sapling \& seedling & -- & -- & -- & $=$ & -- & -- & -- & - \\
\hline All stands & 72,159 & -- & -- & -- & 1,023 & -- & 895 & -- \\
\hline \multicolumn{9}{|l|}{ Balsam fir } \\
\hline Sawtimber & 91,780 & -- & -- & -- & -- & 2,750 & 13,186 & \\
\hline Poletimber & 98,005 & -- & -- & 691 & -- & -- & 6,688 & 11,121 \\
\hline Sapling \& seedling & 20,159 & -- & 486 & 1,157 & 443 & 1,724 & 1,946 & 3,788 \\
\hline All stands & 209,944 & -- & 486 & 1,848 & 443 & 4,474 & 21,820 & 16,636 \\
\hline \multicolumn{9}{|l|}{ White spruce } \\
\hline Sawtimber & 45,810 & -- & -- & -- & -- & -- & -- & -- \\
\hline Poletimber & 25,097 & -- & -- & -- & -- & -- & -- & -- \\
\hline Sapling \& seedling & 499 & -- & -- & -- & -- & -- & 499 & -- \\
\hline Al 1 stands & 71,406 & -- & -- & -- & -- & -- & 499 & -- \\
\hline \multicolumn{9}{|l|}{ Black spruce } \\
\hline Sawtimber & 2,813 & -- & -- & -- & -- & -- & -- & -- \\
\hline Poletimber & 21,143 & -- & -- & -- & -- & -- & 2,048 & 1,358 \\
\hline Sapling \& seedling & 13,418 & -- & 132. & 1,406 & 492 & 5,039 & 906 & 1,378 \\
\hline All stands & 37,374 & -- & 132 & 1,406 & 492 & 5,039 & 2,954 & 2,736 \\
\hline \multicolumn{9}{|l|}{ Northern white-cedar } \\
\hline Sawtimber & 60,374 & -- & -- & -- & -- & -- & 304 & 2,045 \\
\hline Poletimber & 52,829 & -- & -- & - & -- & -- & 1,710 & - \\
\hline Sapling \& seedling & 2,126 & -- & 30 & -- & -- & -- & 1,441 & -- \\
\hline All stands & 115,329 & -- & 30 & -- & -- & -- & 3,455 & 2,045 \\
\hline
\end{tabular}


(Table 36 continued)

\begin{tabular}{|c|c|c|c|c|c|c|c|}
\hline \multirow{2}{*}{$\begin{array}{l}\text { Forest type and } \\
\text { stand-size class }\end{array}$} & \multicolumn{7}{|c|}{ Basal-area class (square feet per acre) } \\
\hline & $71-80$ & $81-90$ & $91-100$ & $101-120$ & $121-150$ & $151-180$ & $181+$ \\
\hline $\begin{array}{l}\text { Jack pine } \\
\text { Sawtimber } \\
\text { Poletimber } \\
\text { Sapling \& seedling }\end{array}$ & $\begin{array}{r}8,439 \\
18,545 \\
7,521 \\
\end{array}$ & $\begin{array}{r}6,130 \\
14,098 \\
1,573 \\
\end{array}$ & $\begin{array}{r}1,165 \\
66,258 \\
-- \\
\end{array}$ & $\begin{array}{r}14,323 \\
32,024 \\
\ldots- \\
\end{array}$ & $\begin{array}{r}3,455 \\
7,177 \\
-- \\
\end{array}$ & $\begin{array}{r}-- \\
3,177 \\
-- \\
\end{array}$ & $\begin{array}{l}-- \\
-- \\
--\end{array}$ \\
\hline All stands & 34,505 & 21,801 & 67,423 & 46,347 & 10,632 & 3,177 & -- \\
\hline $\begin{array}{l}\text { Red pine } \\
\text { Sawtimber } \\
\text { Poletimber } \\
\text { Sapling \& seedling }\end{array}$ & $\begin{array}{r}-- \\
625 \\
2,171 \\
2706\end{array}$ & $\begin{array}{r}1,415 \\
4,644 \\
-- \\
6,050\end{array}$ & $\begin{array}{r}5,433 \\
5,991 \\
-- \\
11\end{array}$ & $\begin{array}{r}35,737 \\
10,689 \\
1,005 \\
17\end{array}$ & $\begin{array}{r}27,785 \\
11,485 \\
-- \\
39\end{array}$ & $\begin{array}{r}38,609 \\
12,962 \\
-- \\
51 \quad 571\end{array}$ & $\begin{array}{r}6,580 \\
-- \\
-- \\
5,580\end{array}$ \\
\hline All stands & 2,796 & 6,059 & 11,424 & 47,431 & 39,270 & 51,571 & 6,580 \\
\hline $\begin{array}{l}\text { White pine } \\
\text { Sawtimber } \\
\text { Poletimber } \\
\text { Sapling \& seedling }\end{array}$ & $\begin{array}{l}-- \\
-- \\
--\end{array}$ & $\begin{array}{r}2,313 \\
2,619 \\
-- \\
\end{array}$ & $\begin{array}{l}-- \\
-- \\
--\end{array}$ & $\begin{array}{r}20,605 \\
3,270 \\
- \\
\end{array}$ & $\begin{array}{r}18,125 \\
2,414 \\
-- \\
\end{array}$ & $\begin{array}{r}20,895 \\
-- \\
-- \\
\end{array}$ & -- \\
\hline Al1 stands & -- & 4,932 & -- & 23,875 & 20,539 & 20,895 & -- \\
\hline $\begin{array}{l}\text { Balsam fir } \\
\text { Sawtimber } \\
\text { Poletimber } \\
\text { Sapling \& seedling }\end{array}$ & $\begin{array}{l}5,768 \\
1,159 \\
5,793 \\
\end{array}$ & $\begin{array}{r}4,090 \\
11,208 \\
1,213 \\
\end{array}$ & $\begin{array}{l}2,924 \\
5,044 \\
2,237 \\
\end{array}$ & $\begin{array}{r}19,908 \\
12,142 \\
-- \\
\end{array}$ & $\begin{array}{r}32,253 \\
20,789 \\
-- \\
\end{array}$ & $\begin{array}{r}6,338 \\
23,490 \\
1,372 \\
\end{array}$ & $\begin{array}{r}2,836 \\
5,673 \\
-- \\
\end{array}$ \\
\hline All stands & 12,720 & 16,511 & 10,205 & 32,050 & 53,042 & 31,200 & 8,509 \\
\hline $\begin{array}{l}\text { White spruce } \\
\text { Sawtimber } \\
\text { Poletimber } \\
\text { Sapling \& seedling }\end{array}$ & $\begin{array}{l}-- \\
-- \\
--\end{array}$ & $\begin{array}{l}-- \\
-- \\
--\end{array}$ & $\begin{array}{l}-- \\
-- \\
-\end{array}$ & $\begin{array}{l}-- \\
-- \\
-\end{array}$ & 17,955 & $\begin{array}{r}10,657 \\
7,142 \\
-- \\
\end{array}$ & $\begin{array}{r}35,153 \\
-- \\
-- \\
\end{array}$ \\
\hline Al1 stands & -- & -- & -- & -- & 17,955 & 17,799 & 35,153 \\
\hline $\begin{array}{l}\text { Black spruce } \\
\text { Sawtimber } \\
\text { Poletimber } \\
\text { Sapling \& seedling }\end{array}$ & $\begin{array}{r}6,787 \\
856 \\
7643\end{array}$ & $\begin{array}{l}1,21 \overline{3} \\
1,784 \\
2007\end{array}$ & $\begin{array}{r}-\overline{-} \\
1,861 \\
415 \\
2\end{array}$ & $\begin{array}{r}-- \\
1,405 \\
-- \\
1\end{array}$ & $\begin{array}{l}2,813 \\
6,471 \\
1,010 \\
10,294\end{array}$ & $\begin{array}{l}-- \\
-- \\
-- \\
--\end{array}$ & $\begin{array}{l}-- \\
-- \\
--\end{array}$ \\
\hline$\frac{\text { All stands }}{\text { Nerthern white-cedar }}$ & 7,643 & 2,997 & 2,276 & 1,405 & 10,294 & -- & - \\
\hline $\begin{array}{l}\text { Northern white-cedar } \\
\text { Sawtimber } \\
\text { Poletimber } \\
\text { Sapling \& seedling }\end{array}$ & $\begin{array}{r}2,866 \\
1,078 \\
-- \\
\end{array}$ & $\begin{array}{r}1,529 \\
4,304 \\
-- \\
\end{array}$ & $\begin{array}{r}2,748 \\
-- \\
-- \\
\end{array}$ & $\begin{array}{r}-- \\
29,429 \\
-- \\
\end{array}$ & $\begin{array}{r}18,270 \\
8,371 \\
-- \\
\end{array}$ & $\begin{array}{r}13,014 \\
7,937 \\
655 \\
\end{array}$ & $\begin{array}{r}19,598 \\
-- \\
-- \\
\end{array}$ \\
\hline Al1 stands & 3,944 & 5,833 & 2,748 & 29,429 & 26,641 & 21,606 & 19,598 \\
\hline
\end{tabular}


(Table 36 continued)

\begin{tabular}{|c|c|c|c|c|c|c|c|c|}
\hline \multirow{2}{*}{$\begin{array}{l}\text { Forest type and } \\
\text { stand-size class }\end{array}$} & \multirow{2}{*}{$\begin{array}{c}\text { All } \\
\text { classes }\end{array}$} & \multicolumn{7}{|c|}{ Basal-area class (square feet per acre) } \\
\hline & & $0-10$ & $11-20$ & $21-30$ & $31-40$ & $41-50$ & $51-60$ & $61-70$ \\
\hline $\begin{array}{l}\text { Tamarack } \\
\text { Sawtimber } \\
\text { Poletimber } \\
\text { Sapl ing \& seedling }\end{array}$ & $\begin{array}{r}8,936 \\
30,768 \\
15,956 \\
\end{array}$ & $\begin{array}{l}-- \\
93 \\
\end{array}$ & $\begin{array}{r}380 \\
-- \\
218 \\
\end{array}$ & $\begin{array}{r}-- \\
430 \\
1,947 \\
\end{array}$ & $\begin{array}{r}-- \\
-- \\
1,627 \\
\end{array}$ & $\begin{array}{l}1,089 \\
2,405 \\
1,063 \\
\end{array}$ & $\begin{array}{l}1,121 \\
2,829 \\
4,247\end{array}$ & $\begin{array}{l}1,474 \\
8,983 \\
1,009\end{array}$ \\
\hline All stands & 55,660 & 93 & 598 & 2,377 & 1,627 & 4,557 & 8,197 & 11,466 \\
\hline $\begin{array}{l}\text { Oak-hickory } \\
\text { Sawtimber } \\
\text { Poletimber } \\
\text { Sapl ing \& seedling }\end{array}$ & $\begin{array}{r}150,915 \\
245,974 \\
26,504 \\
\end{array}$ & $\begin{array}{r}-- \\
272 \\
\end{array}$ & $\begin{array}{r}-- \\
1,087 \\
\end{array}$ & $\begin{array}{r}5 \overrightarrow{56} \\
2,195 \\
\end{array}$ & $\begin{array}{r}2,248 \\
-- \\
7,339 \\
\end{array}$ & $\begin{array}{r}1,579 \\
444 \\
9,828 \\
\end{array}$ & $\begin{array}{r}960 \\
2,267 \\
2,655 \\
\end{array}$ & $\begin{array}{r}10,350 \\
5,139 \\
-- \\
\end{array}$ \\
\hline All stands & 423,393 & 272 & 1,087 & 2,751 & 9,587 & 11,851 & 5,882 & 15,489 \\
\hline $\begin{array}{l}\text { Elm-ash-soft maple } \\
\text { Sawtimber } \\
\text { Poletimber } \\
\text { Sapl ing \& seedling }\end{array}$ & $\begin{array}{r}131,670 \\
224,186 \\
30,379 \\
\end{array}$ & $\begin{array}{r}-- \\
213 \\
\end{array}$ & $\begin{array}{r}624 \\
-- \\
336 \\
\end{array}$ & $\begin{array}{r}1,353 \\
704 \\
3,706 \\
\end{array}$ & $\begin{array}{l}1,970 \\
1,743 \\
1,719 \\
\end{array}$ & $\begin{array}{l}1,204 \\
6,881 \\
5,627 \\
\end{array}$ & $\begin{array}{l}8,010 \\
9,420 \\
6,443 \\
\end{array}$ & $\begin{array}{r}2,501 \\
12,034 \\
1,877 \\
\end{array}$ \\
\hline All stands & 386,235 & 213 & 960 & 5,763 & 5,432 & 13,712 & 23,873 & 16,412 \\
\hline $\begin{array}{l}\text { Maple-birch } \\
\text { Sawtimber } \\
\text { Poletimber } \\
\text { Sapling \& seedling }\end{array}$ & $\begin{array}{r}739,515 \\
1,094,515 \\
94,873 \\
\end{array}$ & $\begin{array}{r}-- \\
17 \overline{3} \\
\end{array}$ & $\begin{array}{r}-- \\
1,160 \\
\end{array}$ & $\begin{array}{r}546 \\
-- \\
3,862 \\
\end{array}$ & $\begin{array}{r}930 \\
1,743 \\
4,151 \\
\end{array}$ & $\begin{array}{r}-- \\
6,223 \\
12,855 \\
\end{array}$ & $\begin{array}{r}4,830 \\
12,031 \\
14,199 \\
\end{array}$ & $\begin{array}{l}11,592 \\
19,791 \\
14,650 \\
\end{array}$ \\
\hline All stands & $1,928,903$ & 173 & 1,160 & 4,408 & 6,824 & 19,078 & 31,060 & 46,033 \\
\hline $\begin{array}{l}\text { Aspen } \\
\text { Sawtimber } \\
\text { Pol etimber } \\
\text { Sapl ing \& seedling }\end{array}$ & $\begin{array}{l}233,445 \\
923,535 \\
158,438 \\
\end{array}$ & $\begin{array}{r}-- \\
1,237 \\
\end{array}$ & $\begin{array}{r}-- \\
226 \\
7,351 \\
\end{array}$ & $\begin{array}{r}2,436 \\
4,961 \\
16,229 \\
\end{array}$ & $\begin{array}{r}3,503 \\
8,769 \\
19,974 \\
\end{array}$ & $\begin{array}{r}6,633 \\
24,485 \\
27,159 \\
\end{array}$ & $\begin{array}{r}9,320 \\
57,638 \\
23,431 \\
\end{array}$ & $\begin{array}{l}14,573 \\
54,494 \\
15,656 \\
\end{array}$ \\
\hline A11 stands & $1,315,418$ & 1,237 & 7,577 & 23,626 & 32,246 & 58,277 & 90,389 & 84,723 \\
\hline $\begin{array}{l}\text { Paper birch } \\
\text { Sawtimber } \\
\text { Poletimber } \\
\text { Sapling \& seedling }\end{array}$ & $\begin{array}{r}33,319 \\
247,256 \\
22,638 \\
\end{array}$ & $\begin{array}{l}-- \\
-- \\
--\end{array}$ & $\begin{array}{l}-- \\
-- \\
-- \\
\end{array}$ & $\begin{array}{r}-- \\
680 \\
864 \\
\end{array}$ & $\begin{array}{r}-- \\
3,028 \\
1,429 \\
\end{array}$ & $\begin{array}{l}1,091 \\
1,701 \\
4,815 \\
\end{array}$ & $\begin{array}{r}-- \\
39,926 \\
3,826 \\
\end{array}$ & $\begin{array}{r}-- \\
5,019 \\
3,875 \\
\end{array}$ \\
\hline A11 stands & 303,213 & - & - & 1,544 & 4,457 & 7,607 & 23,752 & 8,894 \\
\hline $\begin{array}{l}\text { Exotic } \\
\text { Sawtimber } \\
\text { Poletimber } \\
\text { Sapl ing \& seedling }\end{array}$ & $\begin{array}{l}-- \\
-- \\
--\end{array}$ & $\begin{array}{l}-- \\
-- \\
--\end{array}$ & $\begin{array}{l}-- \\
-- \\
--\end{array}$ & $\begin{array}{l}-- \\
-- \\
--\end{array}$ & $\begin{array}{l}-- \\
-- \\
--\end{array}$ & $\begin{array}{l}-- \\
-- \\
-- \\
\end{array}$ & $\begin{array}{l}-- \\
-- \\
-\end{array}$ & $\begin{array}{l}-- \\
-- \\
--\end{array}$ \\
\hline All stands & -- & -- & -- & -- & -- & -- & -- & - \\
\hline Nonstocked & 5,834 & 902 & 914 & 303 & 1,144 & 316 & 1,315 & 829 \\
\hline $\begin{array}{l}\text { All types } \\
\text { Sawtimber } \\
\text { Poletimber } \\
\text { Sapl ing \& seedling } \\
\text { Nonstocked }\end{array}$ & $\begin{array}{r}1,723,771 \\
3,175,054 \\
406,731 \\
5,834 \\
\end{array}$ & $\begin{array}{r}-- \\
-- \\
2,072 \\
902 \\
\end{array}$ & $\begin{array}{r}1,004 \\
226 \\
10,800 \\
914 \\
\end{array}$ & $\begin{array}{r}4,335 \\
8,022 \\
32,704 \\
303 \\
\end{array}$ & $\begin{array}{r}11,137 \\
16,327 \\
40,095 \\
1,144 \\
\end{array}$ & $\begin{array}{r}17,240 \\
43,761 \\
69,511 \\
316 \\
\end{array}$ & $\begin{array}{r}41,906 \\
121,574 \\
63,114 \\
1,315 \\
\end{array}$ & $\begin{array}{r}48,892 \\
124,024 \\
42,439 \\
829 \\
\end{array}$ \\
\hline All stands & $5,311,390$ & 2,974 & 12,944 & 45,364 & 68,703 & 130,828 & 227,909 & 216,184 \\
\hline
\end{tabular}




\begin{tabular}{|c|c|c|c|c|c|c|c|}
\hline \multirow{2}{*}{$\begin{array}{l}\text { Forest type and } \\
\text { stand-size class }\end{array}$} & \multicolumn{7}{|c|}{ Basal-area class (square feet per acre) } \\
\hline & $71-80$ & $81-90$ & $91-100$ & $101-120$ & $121-150$ & $151-180$ & $181+$ \\
\hline \multicolumn{8}{|l|}{ Tamarack } \\
\hline Sawtimber & -- & -- & -- & 4,872 & -- & -- & - \\
\hline Poletimber & -- & 6,966 & 1,712 & 6,232 & 1,211 & -- & -- \\
\hline Sapl ing \& seedl ing & 2,495 & 890 & 2,367 & - & -- & -- & -- \\
\hline All stands & 2,495 & 7,856 & 4,079 & 11,104 & 1,211 & -- & -- \\
\hline \multicolumn{8}{|l|}{ Oak-hickory } \\
\hline Sawtimber & 1,338 & 16,738 & 7,532 & 50,835 & 50,961 & 8,374 & -- \\
\hline Poletimber & 12,223 & 27,504 & 29,420 & 85,087 & 34,424 & 48,910 & -- \\
\hline Sapl ing \& seedling & 1,148 & 1,909 & -- & 71 & & -- & - \\
\hline All stands & 14,709 & 46,151 & 36,952 & 135,993 & 85,385 & 57,284 & -- \\
\hline \multicolumn{8}{|l|}{ Elm-ash-soft maple } \\
\hline Sawtimber & 655 & 12,734 & 1,628 & 26,131 & 53,547 & 21,313 & -- \\
\hline Poletimber & 28,623 & 37,360 & 31,710 & 27,478 & 49,611 & 16,020 & 2,602 \\
\hline Sapling \& seedling & 2,021 & 5,136 & 2,510 & - & 791 & -- & -- \\
\hline All stands & 31,299 & 55,230 & 35,848 & 53,609 & 103,949 & 37,333 & 2,602 \\
\hline \multicolumn{8}{|l|}{ Maple-birch } \\
\hline Sawtimber & 25,494 & 41,149 & 49,778 & 142,535 & 265,907 & 163,237 & 33,517 \\
\hline Poletimber & 56,290 & 103,865 & 87,240 & $3 \div 1,259$ & 343,847 & 144,685 & 7,541 \\
\hline Sapling \& seedling & 9,782 & 8,840 & 5,165 & 17,175 & 1,391 & 1,470 & -- \\
\hline All stands & 91,566 & 153,854 & 142,183 & 470,969 & 611,145 & 309,392 & 41,058 \\
\hline \multirow{2}{*}{\multicolumn{8}{|c|}{$\begin{array}{l}\text { Aspen } \\
\text { Sawtimber }\end{array}$}} \\
\hline Sawtimber & & & & & & & \\
\hline Poletimber & 70,768 & 131,078 & 84,656 & 171,083 & 228,357 & 74,631 & 12,389 \\
\hline Sapling \& seedling & 23,919 & 13,740 & 1,913 & 5,867 & 1,962 & -- & -- \\
\hline All stands & 111,573 & 172,524 & 100,929 & 207,321 & 322,998 & 89,609 & 12,389 \\
\hline \multirow{2}{*}{\multicolumn{8}{|c|}{ Paper birch }} \\
\hline Sawtimber & 3,097 & 1,015 & 1,461 & 9,412 & 13,824 & 3,419 & \\
\hline Poletimber & 8,854 & 13,535 & 23,921 & 46,216 & 86,225 & 30,255 & 7,896 \\
\hline Sapling \& seedling & 846 & 1,690 & 2,549 & 2,744 & -- & -- & -- \\
\hline A11 stands & 12,797 & 16,240 & 27,931 & 58,372 & 100,049 & 33,674 & 7,896 \\
\hline \multicolumn{8}{|l|}{ Exotic } \\
\hline Sawtimber & -- & -- & -- & -- & -- & -- & -- \\
\hline Poletimber & -- & -- & -- & -- & -- & -- & -- \\
\hline Sapling \& seedling & -- & -- & -- & -- & -- & -- & -- \\
\hline All stands & -- & -- & -- & -- & -- & -- & -- \\
\hline Nonstocked & -- & -- & 111 & -- & -- & -- & - \\
\hline \multicolumn{8}{|l|}{ A11 types } \\
\hline $\begin{array}{l}\text { Sawtimber } \\
\text { Poletimber }\end{array}$ & $\begin{array}{r}64,543 \\
204,952\end{array}$ & $\begin{array}{l}114,819 \\
358,394\end{array}$ & $\begin{array}{r}87,029 \\
337,813\end{array}$ & $\begin{array}{l}354,729 \\
736,314\end{array}$ & $\begin{array}{l}579,619 \\
818,337\end{array}$ & $\begin{array}{l}300,834 \\
369,209\end{array}$ & $\begin{array}{l}97,684 \\
36,101\end{array}$ \\
\hline Sapling \& seedling & 56,552 & 36,775 & 17,156 & 26,862 & 5,154 & 3,497 & -- \\
\hline Nonstocked & -- & -- & 111 & -- & -- & -- & -- \\
\hline ATT stands & 326,047 & 509,988 & 442,109 & $1,117,905$ & $1,403,110$ & 673,540 & 133,785 \\
\hline
\end{tabular}


Table 37.--Net volume of sawtimber on commercial forest land by forest type, stand-size class, and basal-area class, Northwest Unit, Wisconsin, 1983

(In thousand board feet) 1 /

\begin{tabular}{|c|c|c|c|c|c|c|c|c|}
\hline \multirow{2}{*}{$\begin{array}{l}\text { Forest type and } \\
\text { stand-size class }\end{array}$} & \multirow{2}{*}{$\begin{array}{c}\text { A11 } \\
\text { classes }\end{array}$} & \multicolumn{7}{|c|}{ Basal-area class (square feet per acre) } \\
\hline & & $0-10$ & $11-20$ & $21-30$ & $31-40$ & $41-50$ & $51-60$ & $61-70$ \\
\hline $\begin{array}{l}\text { Jack pine } \\
\text { Sawtimber } \\
\text { Poletimber } \\
\text { Sapling \& seedling } \\
\text { All stands }\end{array}$ & $\begin{array}{r}141,457 \\
166,226 \\
23,831 \\
331,514\end{array}$ & $\begin{array}{l}-- \\
-- \\
-- \\
--\end{array}$ & $\begin{array}{l}-- \\
-- \\
-- \\
--\end{array}$ & $\begin{array}{r}-- \\
-- \\
1,419 \\
1,419\end{array}$ & $\begin{array}{l}2,541 \\
1,933 \\
3,288 \\
7,762 \\
\end{array}$ & $\begin{array}{r}3,055 \\
-- \\
4,935 \\
7,990\end{array}$ & $\begin{array}{r}5,994 \\
4,517 \\
4,572 \\
15,083 \\
\end{array}$ & $\begin{array}{r}15,914 \\
8,650 \\
-- \\
24,564\end{array}$ \\
\hline $\begin{array}{l}\text { Red pine } \\
\text { Sawtimber } \\
\text { Poletimber } \\
\text { Sapl ing \& seedling } \\
\text { All stands }\end{array}$ & $\begin{array}{r}465,264 \\
64,872 \\
6,566 \\
536,702\end{array}$ & $\begin{array}{l}-- \\
-- \\
-- \\
--\end{array}$ & $\begin{array}{l}-- \\
-- \\
--\end{array}$ & $\begin{array}{l}-- \\
-- \\
--\end{array}$ & $\begin{array}{r}3,201 \\
--- \\
5,045 \\
8,246\end{array}$ & $\begin{array}{r}10,381 \\
-- \\
-- \\
10,381\end{array}$ & $\begin{array}{r}8,288 \\
4,906 \\
--- \\
13,194\end{array}$ & $\begin{array}{l}-- \\
-- \\
-- \\
--\end{array}$ \\
\hline $\begin{array}{l}\text { White pine } \\
\text { Sawtimber } \\
\text { Poletimber } \\
\text { Sapl ing \& seedling }\end{array}$ & $\begin{array}{r}252,829 \\
18,518 \\
-- \\
\end{array}$ & $\begin{array}{l}-- \\
-- \\
--\end{array}$ & $\begin{array}{l}-- \\
-- \\
--\end{array}$ & $\begin{array}{l}-- \\
-- \\
--\end{array}$ & $\begin{array}{r}5,132 \\
-- \\
-- \\
\end{array}$ & $\begin{array}{l}-- \\
-- \\
-\end{array}$ & $\begin{array}{r}2,742 \\
-- \\
-- \\
\end{array}$ & $\begin{array}{l}-- \\
-- \\
--\end{array}$ \\
\hline All stands & 271,347 & -- & - & -- & 5,132 & -- & 2,742 & -- \\
\hline $\begin{array}{l}\text { Balsam fir } \\
\text { Sawtimber } \\
\text { Poletimber } \\
\text { Sapling \& seedling }\end{array}$ & $\begin{array}{r}288,747 \\
135,810 \\
36,126 \\
\end{array}$ & $\begin{array}{l}-- \\
-- \\
--\end{array}$ & $\begin{array}{l}-- \\
-- \\
-\end{array}$ & $\begin{array}{r}-\overline{1} \\
2,114 \\
2,233\end{array}$ & $\begin{array}{l}-- \\
776 \\
\end{array}$ & $\begin{array}{r}8,050 \\
-- \\
5,610 \\
\end{array}$ & $\begin{array}{r}50,349 \\
13,103 \\
4,454 \\
\end{array}$ & $\begin{array}{l}5,687 \\
8,158 \\
5,747 \\
\end{array}$ \\
\hline All stands & 460,683 & -- & - & 3,347 & 776 & 13,660 & 67,906 & 19,592 \\
\hline $\begin{array}{l}\text { White spruce } \\
\text { Sawtimber } \\
\text { Poletimber } \\
\text { Sapling \& seedling }\end{array}$ & $\begin{array}{r}135,936 \\
25,509 \\
-- \\
\end{array}$ & $\begin{array}{l}-- \\
-- \\
--\end{array}$ & $\begin{array}{l}-- \\
-- \\
-\end{array}$ & $\begin{array}{l}-- \\
-- \\
--\end{array}$ & $\begin{array}{l}-- \\
-- \\
--\end{array}$ & $\begin{array}{l}-- \\
-- \\
--\end{array}$ & $\begin{array}{l}-- \\
-- \\
--\end{array}$ & $\begin{array}{l}-- \\
-- \\
--\end{array}$ \\
\hline All stands & 161,445 & - & $=$ & $=$ & -- & - & $=$ & -- \\
\hline $\begin{array}{l}\text { Bl ack spruce } \\
\text { Sawtimber } \\
\text { Poletimber } \\
\text { Sapl ing \& seedling }\end{array}$ & $\begin{array}{r}8,000 \\
26,032 \\
12,059 \\
\end{array}$ & $\begin{array}{l}-- \\
-- \\
-\end{array}$ & $\begin{array}{l}-- \\
-- \\
--\end{array}$ & $\begin{array}{r}-- \\
1,344 \\
\end{array}$ & $\begin{array}{l}-- \\
-- \\
--\end{array}$ & 6, 416 & $\begin{array}{r}-- \\
1,180 \\
2,197 \\
\end{array}$ & $\begin{array}{r}-\overline{-} \\
503 \\
\end{array}$ \\
\hline All stands & 46,091 & -- & -- & 1,344 & -- & 6,416 & 3,377 & 2,149 \\
\hline $\begin{array}{l}\text { Northern white-cedar } \\
\text { Sawtimber } \\
\text { Poletimber } \\
\text { Sapling \& seedling }\end{array}$ & $\begin{array}{r}191,554 \\
84,396 \\
2,945 \\
\end{array}$ & $\begin{array}{l}-- \\
-- \\
-- \\
\end{array}$ & $\begin{array}{l}-- \\
-- \\
--\end{array}$ & $\begin{array}{l}-- \\
-- \\
--\end{array}$ & $\begin{array}{l}-- \\
-- \\
--\end{array}$ & $\begin{array}{l}-- \\
-- \\
--\end{array}$ & $\begin{array}{r}1,077 \\
899 \\
1,621 \\
\end{array}$ & $\begin{array}{r}8,423 \\
-- \\
-- \\
\end{array}$ \\
\hline All stands & 278,895 & -- & -- & -- & -- & -- & 3,597 & 8,423 \\
\hline
\end{tabular}

1/ International $1 / 4$-inch rule. 
(Table 37 continued)

\begin{tabular}{|c|c|c|c|c|c|c|c|}
\hline \multirow{2}{*}{$\begin{array}{l}\text { Forest type and } \\
\text { stand-size class }\end{array}$} & \multicolumn{7}{|c|}{ Basal-area class (square feet per acre) } \\
\hline & $71-80$ & $81-90$ & $91-100$ & $101-120$ & $121-150$ & $151-180$ & $181+$ \\
\hline $\begin{array}{l}\text { Jack pine } \\
\text { Sawtimber } \\
\text { Poletimber } \\
\text { Sapling \& seedling }\end{array}$ & $\begin{array}{r}30,576 \\
9,785 \\
8,408 \\
\end{array}$ & $\begin{array}{r}24,372 \\
14,948 \\
1,209 \\
\end{array}$ & $\begin{array}{r}4,426 \\
78,489 \\
-- \\
\end{array}$ & $\begin{array}{r}48,596 \\
46,089 \\
-- \\
\end{array}$ & $\begin{array}{r}5,983 \\
1,815 \\
-- \\
\end{array}$ & $\begin{array}{l}-- \\
-- \\
--\end{array}$ & $\begin{array}{l}-- \\
-- \\
--\end{array}$ \\
\hline All stands & 48,769 & 40,529 & 82,915 & 94,685 & 7,798 & -- & -- \\
\hline $\begin{array}{l}\text { Red pine } \\
\text { Sawtimber } \\
\text { Poletimber } \\
\text { Sapling \& seedling }\end{array}$ & $\begin{array}{r}-- \\
993 \\
775 \\
\end{array}$ & $\begin{array}{r}4,016 \\
6,725 \\
-- \\
\end{array}$ & $\begin{array}{r}29,716 \\
3,284 \\
-- \\
\end{array}$ & $\begin{array}{r}118,325 \\
18,338 \\
746 \\
\end{array}$ & $\begin{array}{r}120,601 \\
14,841 \\
-- \\
\end{array}$ & $\begin{array}{r}147,447 \\
15,785 \\
\cdots \\
\end{array}$ & $\begin{array}{r}23,289 \\
-- \\
-- \\
\end{array}$ \\
\hline All stands & 1,768 & 10,741 & 33,000 & 137,409 & 135,442 & 163,232 & 23,289 \\
\hline $\begin{array}{l}\text { White pine } \\
\text { Sawtimber } \\
\text { Poletimber } \\
\text { Sapling \& seedling }\end{array}$ & $\begin{array}{l}-- \\
-- \\
--\end{array}$ & $\begin{array}{r}8,463 \\
7,007 \\
-- \\
\end{array}$ & $\begin{array}{l}-- \\
-- \\
--\end{array}$ & $\begin{array}{r}77,080 \\
8,290 \\
-- \\
\end{array}$ & $\begin{array}{r}77,290 \\
3,221 \\
-- \\
\end{array}$ & $\begin{array}{r}82,122 \\
-- \\
-- \\
\end{array}$ & $\begin{array}{l}-- \\
-- \\
--\end{array}$ \\
\hline All stands & -- & 15,470 & -- & 85,370 & 80,511 & 82,122 & -- \\
\hline $\begin{array}{l}\text { Balsam fir } \\
\text { Sawtimber } \\
\text { Poletimber } \\
\text { Sapling \& seedling }\end{array}$ & $\begin{array}{r}20,971 \\
2,037 \\
6,710 \\
\end{array}$ & $\begin{array}{r}11,910 \\
21,166 \\
2,830 \\
\end{array}$ & $\begin{array}{l}7,938 \\
6,207 \\
4,247 \\
\end{array}$ & $\begin{array}{r}63,120 \\
14,001 \\
-- \\
\end{array}$ & $\begin{array}{r}96,790 \\
34,075 \\
-- \\
\end{array}$ & $\begin{array}{r}18,028 \\
30,635 \\
3,519 \\
\end{array}$ & $\begin{array}{r}5,904 \\
5,314 \\
-- \\
\end{array}$ \\
\hline All stands & 29,718 & 35,906 & 18,392 & 77,121 & 130,865 & 52,182 & 11,218 \\
\hline $\begin{array}{l}\text { White spruce } \\
\text { Sawtimber } \\
\text { Poletimber } \\
\text { Sapling \& seedling }\end{array}$ & $\begin{array}{l}-- \\
-- \\
--\end{array}$ & $\begin{array}{l}-- \\
-- \\
-- \\
\end{array}$ & $\begin{array}{l}-- \\
-- \\
--\end{array}$ & $\begin{array}{l}-- \\
-- \\
--\end{array}$ & $\begin{array}{r}-- \\
13,869 \\
-- \\
\end{array}$ & $\begin{array}{r}37,464 \\
11,640 \\
-- \\
\end{array}$ & $\begin{array}{r}98,472 \\
-- \\
-- \\
\end{array}$ \\
\hline All stands & -- & -- & -- & -- & 13,869 & 49,104 & 98,472 \\
\hline $\begin{array}{l}\text { Black spruce } \\
\text { Sawtimber } \\
\text { Poletimber } \\
\text { Sapling \& seedling }\end{array}$ & $\begin{array}{r}-- \\
6,388 \\
-- \\
\end{array}$ & $\begin{array}{l}-- \\
2,294 \\
1,599 \\
\end{array}$ & $\begin{array}{r}-- \\
2,630 \\
-- \\
\end{array}$ & $\begin{array}{r}-- \\
2,603 \\
-- \\
\end{array}$ & $\begin{array}{r}8,000 \\
9,291 \\
-- \\
\end{array}$ & $\begin{array}{l}-- \\
-- \\
--\end{array}$ & $\begin{array}{l}-- \\
-- \\
--\end{array}$ \\
\hline A11 stands & 6,388 & 3,893 & 2,630 & 2,603 & 17,291 & -- & -- \\
\hline $\begin{array}{l}\text { Northern white-cedar } \\
\text { Sawtimber } \\
\text { Poletimber } \\
\text { Sapling \& seedling }\end{array}$ & $\begin{array}{r}11,612 \\
1,182 \\
-- \\
\end{array}$ & $\begin{array}{r}5,447 \\
6,861 \\
-- \\
\end{array}$ & $\begin{array}{r}11,505 \\
-- \\
-- \\
\end{array}$ & 49,510 & $\begin{array}{r}55,107 \\
12,519 \\
- \\
\end{array}$ & $\begin{array}{r}42,410 \\
13,425 \\
1,324 \\
\end{array}$ & $\begin{array}{r}55,973 \\
-- \\
-- \\
\end{array}$ \\
\hline Al1 stands & 12,794 & 12,308 & 11,505 & 49,510 & 67,626 & 57,159 & 55,973 \\
\hline
\end{tabular}


(Table 37 continued)

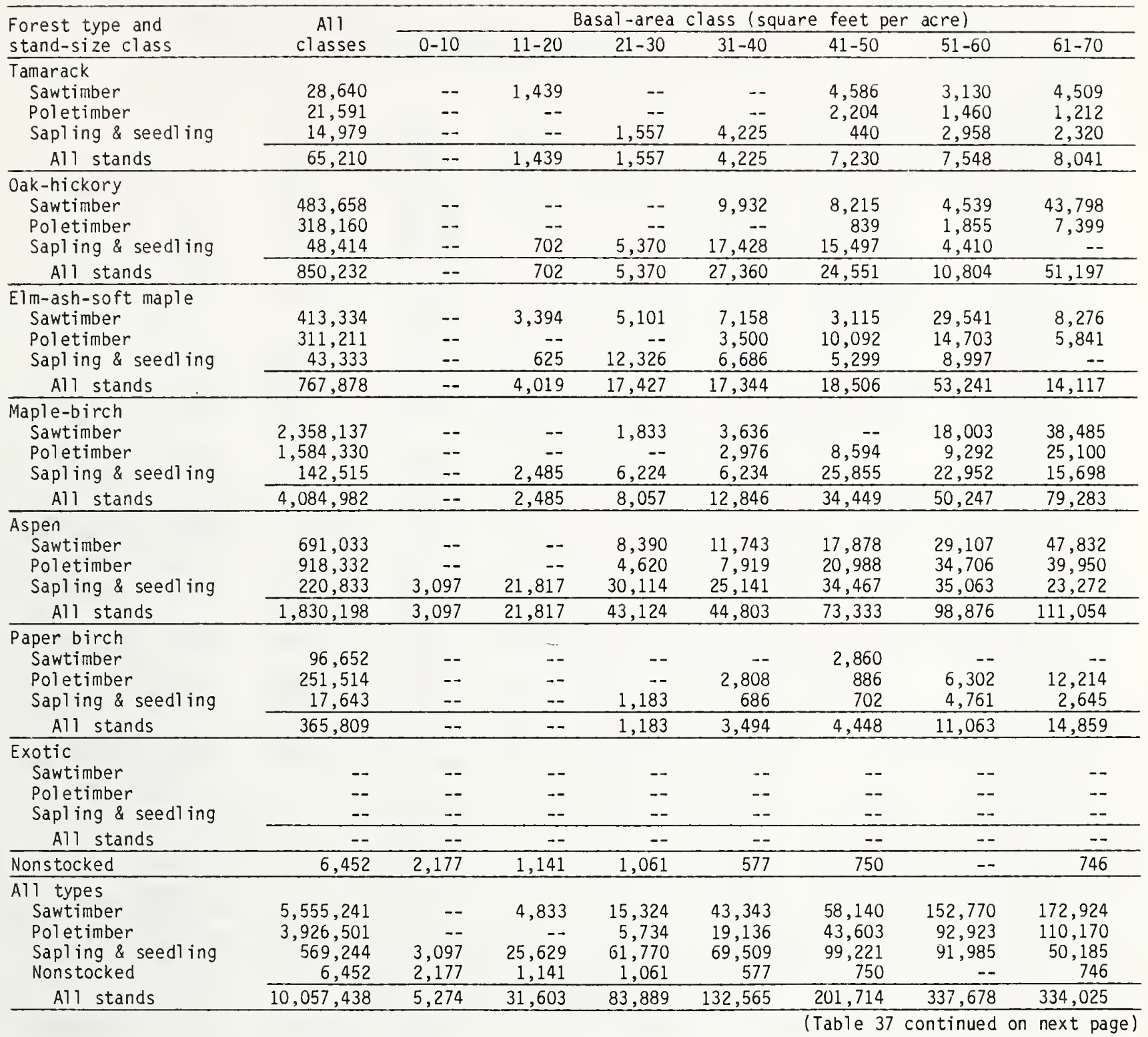


(Table 37 continued)

\begin{tabular}{|c|c|c|c|c|c|c|c|}
\hline \multirow{2}{*}{$\begin{array}{l}\text { Forest type and } \\
\text { stand-size class }\end{array}$} & \multicolumn{7}{|c|}{ Basal-area class (square feet per acre) } \\
\hline & $71-80$ & $81-90$ & $91-100$ & $101-120$ & $121-150$ & $151-180$ & $181+$ \\
\hline \multicolumn{8}{|l|}{ Tamarack } \\
\hline Sawtimber & -- & -- & -- & 14,976 & -- & -- & -- \\
\hline Poletimber & -- & 8,716 & 2,597 & 4,047 & 1,355 & -- & -- \\
\hline Sapling \& seedling & -- & 2,187 & 1,292 & -. & -- & -- & -- \\
\hline A11 stands & -- & 10,903 & 3,889 & 19,023 & 1,355 & -- & -- \\
\hline \multicolumn{8}{|l|}{ Oak-hickory } \\
\hline $\begin{array}{l}\text { Sawtimber } \\
\text { Poletimber }\end{array}$ & $\begin{array}{r}5,082 \\
15,752\end{array}$ & $\begin{array}{l}48,235 \\
43,507\end{array}$ & $\begin{array}{l}30,762 \\
34,539\end{array}$ & $\begin{array}{r}165,000 \\
96,907\end{array}$ & $\begin{array}{r}146,124 \\
51,419\end{array}$ & $\begin{array}{l}21,971 \\
65,943\end{array}$ & -- \\
\hline Sapling \& seedling & 374 & 4,133 & -- & +- & 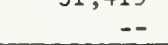 & $\begin{array}{r}0.040 \\
--\end{array}$ & - \\
\hline A11 stands & 21,708 & 95,875 & 65,301 & 261,907 & 197,543 & 87,914 & -- \\
\hline \multicolumn{8}{|l|}{ Elm-ash-soft maple } \\
\hline Sawtimber & 2,449 & 30,549 & 6,903 & 89,989 & 167,142 & 59,717 & -- \\
\hline Poletimber & 41,791 & 65,170 & 44,126 & 33,097 & 64,801 & 25,634 & 2,456 \\
\hline Sapling \& seedling & 470 & 4,363 & 2,528 & -- & 2,039 & -- & -- \\
\hline Al1 stands & 44,710 & 100,082 & 53,557 & 123,086 & 233,982 & 85,351 & 2,456 \\
\hline \multicolumn{8}{|l|}{ Maple-birch } \\
\hline Sawtimber & 86,388 & 149,970 & 152,789 & 483,828 & 810,293 & 521,255 & 91,657 \\
\hline Poletimber & 67,128 & 164,647 & 141,652 & 430,225 & 545,848 & 180,769 & 8,099 \\
\hline Sapling \& seedling & 8,465 & 18,701 & 6,673 & 24,593 & 2,261 & 2,374 & -- \\
\hline A11 stands & 161,981 & 333,318 & 301,114 & 938,646 & $1,358,402$ & 704,398 & 99,756 \\
\hline \multicolumn{8}{|l|}{ Aspen } \\
\hline Sawtimber & 54,243 & 87,052 & 44,684 & 84,517 & 266,707 & 38,880 & -- \\
\hline Poletimber & 75,123 & 153,227 & 88,477 & 191,003 & 230,011 & 68,307 & 4,001 \\
\hline Sapling \& seedling & 28,839 & $\begin{array}{r}7,817 \\
\end{array}$ & 826 & 9,284 & 1,096 & -- & -- \\
\hline All stands & 158,205 & 248,096 & 133,987 & 284,804 & 497,814 & 107,187 & 4,001 \\
\hline \multicolumn{8}{|l|}{ Paper birch } \\
\hline Sawtimber & 10,197 & 3,134 & 3,816 & 28,902 & 36,599 & 11,144 & \\
\hline Poletimber & 10,540 & 13,545 & 29,739 & 50,788 & 83,289 & 33,464 & 7,939 \\
\hline Sapling \& seedling & -- & 2,402 & 613 & 4,651 & -- & -- & -- \\
\hline All stands & 20,737 & 19,081 & 34,168 & 84,341 & 119,888 & 44,608 & 7,939 \\
\hline \multicolumn{8}{|l|}{ Exotic } \\
\hline Sawtimber & -- & -- & -- & -- & -- & -- & -- \\
\hline Poletimber & -- & -- & -- & -- & -- & -- & - \\
\hline Sapling \& seedling & -- & -- & -- & -- & -- & -- & - \\
\hline A11 stands & -- & -- & -- & -- & -- & -- & -- \\
\hline Nonstocked & -- & -- & -- & -- & -- & -- & $\cdots$ \\
\hline \multicolumn{8}{|l|}{ A11 types } \\
\hline Sawtimber & 221,518 & 373,148 & 292,539 & $1,174,333$ & $1,790,636$ & 980,438 & 275,295 \\
\hline Poletimber & 230,719 & 507,813 & 431,740 & 944,898 & $1,066,354$ & 445,602 & 27,809 \\
\hline Sapling \& seedling & 54,541 & 45,241 & 16,179 & 39,274 & 5,396 & 7,217 & -- \\
\hline Nonstocked & -- & -- & -- & -- & -- & -- & -- \\
\hline A11 stands & 506,778 & 926,202 & 740,458 & $2,158,505$ & $2,862,386$ & $1,433,257$ & 303,104 \\
\hline
\end{tabular}


Table 38.--Net volume of sawtimber on commercial forest land by species group and butt $\log$ grade, Northwest Unit, Wisconsin, 1983

(In thousand board feet) 1 !

\begin{tabular}{|c|c|c|c|c|c|}
\hline \multirow[b]{2}{*}{ Species group } & \multirow{2}{*}{$\begin{array}{l}\text { All } \\
\text { grades }\end{array}$} & \multicolumn{4}{|c|}{ Log grade } \\
\hline & & 1 & 2 & 3 & Tie and timber \\
\hline \multicolumn{6}{|l|}{ Softwoods } \\
\hline Jack pine & 403,480 & -- & -- & 403,480 & -- \\
\hline Red pine & 654,363 & -- & 12,177 & 642,186 & -- \\
\hline White pine & 745,829 & 91,585 & 91,626 & 558,760 & 3,858 \\
\hline White spruce & 368,931 & 2,898 & 2,355 & 363,678 & -- \\
\hline 81 ack spruce & 33,543 & -- & -- & 33,543 & -- \\
\hline $8 a 1$ sam fir & 588,647 & -- & -- & 588,617 & -- \\
\hline Hemlock & 264,927 & 25,025 & 43,812 & 196,090 & -- \\
\hline Tamarack & 94,390 & -- & 772 & 93,618 & -- \\
\hline Northern white-cedar & 388,516 & -- & 22,430 & 366,086 & -- \\
\hline Other softwoods & 1,392 & -- & -- & 1,392 & -- \\
\hline Total & $3,544,018$ & 119,508 & 173,172 & $3,247,480$ & 3,858 \\
\hline \multicolumn{6}{|l|}{ Hardwoods } \\
\hline White oak & 202,018 & 9,651 & 33,206 & 139,673 & 19,488 \\
\hline Select red oak & 846,693 & 76,618 & 215,878 & 491,026 & 63,171 \\
\hline other red oak & 100,877 & -- & 21,007 & 79,870 & -- \\
\hline Select hickory & & -- & -. & & -- \\
\hline Other hickory & 9,661 & -- & -- & 6,744 & 2,917 \\
\hline 8asswood & 732,985 & 103,824 & 208,227 & 403,761 & 17,173 \\
\hline 8eech & & & & & \\
\hline Yellow birch & 221,270 & 30,969 & 76,696 & 110,771 & 2,834 \\
\hline Hard maple & 905,072 & 84,792 & 158,329 & 645,155 & 16,796 \\
\hline Soft maple & 498,562 & 40,366 & 68,819 & 367,283 & 22,094 \\
\hline Elm & 411,041 & 47,725 & 136,983 & 216,311 & 10,022 \\
\hline Black ash & 269,758 & 18,605 & 63,966 & 178,843 & 8,344 \\
\hline White \& green ash & 190,571 & 23,062 & 66,534 & 100,975 & -- \\
\hline Sycamore & -- & -- & -- & - & -- \\
\hline Cottonwood & -- & -- & -- & -- & -- \\
\hline Willow & 720 & -- & 328 & 392 & -- \\
\hline Hackberry & & -- & & -- & -- \\
\hline 8alsam poplar & 17,149 & -- & 7,824 & 9,325 & -- \\
\hline Bigtooth aspen & 530,658 & 12,250 & 74,590 & 437,892 & 5,926 \\
\hline Quaking aspen & $1,255,261$ & 30,439 & 153,541 & 968,392 & 102,889 \\
\hline Paper birch & 293,605 & -- & 30,465 & 249,615 & 13,525 \\
\hline 81 ack cherry & 14,138 & -- & 7,592 & 6,546 & -- \\
\hline 81 ack walnut & - & -- & -- & -- & -- \\
\hline Butternut & 13,381 & -- & 6,966 & 6,415 & -- \\
\hline Other hardwoods & -- & -- & - & -- & -- \\
\hline Total & $6,513,420$ & 478,301 & $1,330,951$ & $4,418,989$ & 285,179 \\
\hline All species & $10,057,438$ & 597,809 & $1,504,123$ & $7,666,469$ & 289,037 \\
\hline
\end{tabular}

$1 /$ International $1 / 4$-inch rule. 


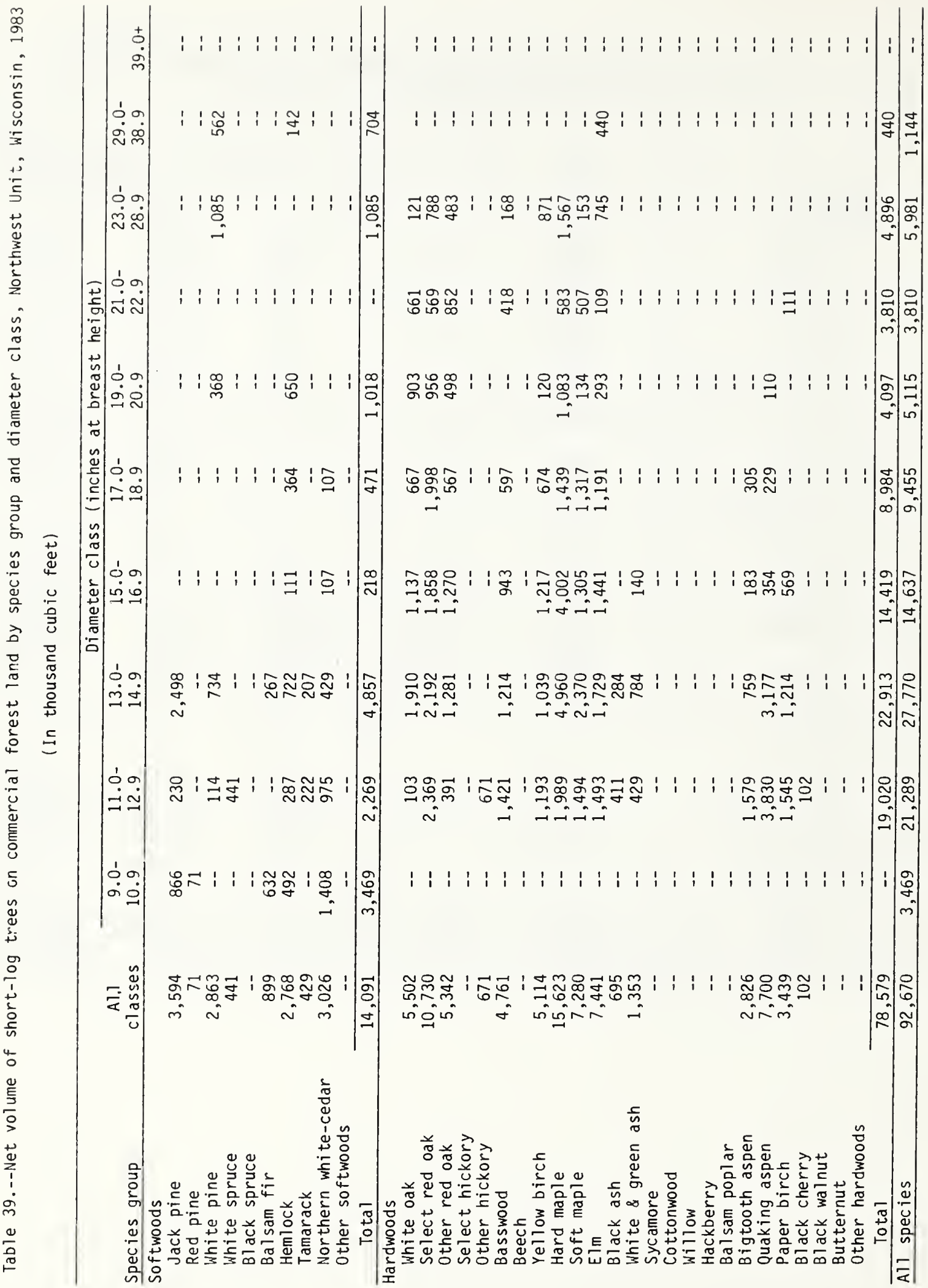




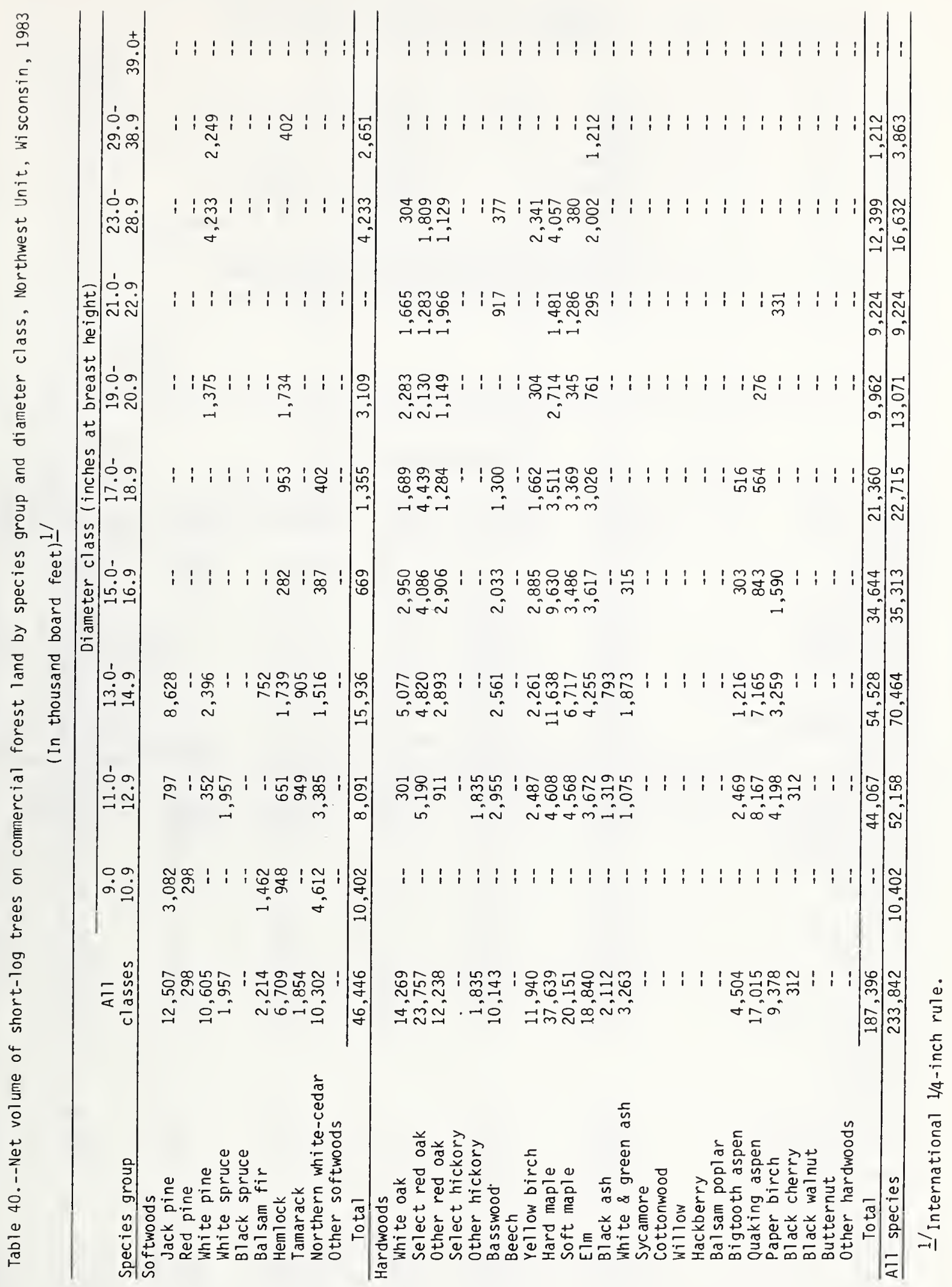


Table 41.--Net annual growth of growing stock on commercial forest 1 and by softwoods and hardwoods, Northwest Unit, Wisconsin, 1967 and 1982

(In thousand cubic feet)

\begin{tabular}{crr}
\hline Species & $1967 \frac{1 /}{1}$ & \multicolumn{1}{c}{1982} \\
\hline Softwoods & 43,000 & 49,537 \\
Hardwoods & 118,000 & 129,690 \\
\hline A11 species & 161,000 & 179,227 \\
\hline
\end{tabular}

$1 /$ Figures have been adjusted from those published after the 1968 survey to conform to 1982 volumes because of changes in survey procedures.

Table 42.--Net annual growth of growing stock on commercial forest land by species group and county, Northwest Unit, Wisconsin, 1982

(In thousand cubic feet)

\begin{tabular}{|c|c|c|c|c|c|c|c|}
\hline \multirow[b]{2}{*}{ Species group } & \multirow{2}{*}{$\begin{array}{c}\text { All } \\
\text { counties }\end{array}$} & \multicolumn{6}{|c|}{ County } \\
\hline & & Ashl and & Barron & Bayfield & Burnett & Douglas & Iron \\
\hline \multicolumn{8}{|l|}{ Softwoods } \\
\hline Jack pine & 10,607 & 3 & 18 & 2,168 & 2,294 & 3,432 & -- \\
\hline Red pine & 8,768 & 693 & 15 & 2,398 & 1,430 & 749 & 194 \\
\hline White pine & 4,234 & 622 & 107 & 1,174 & 222 & 176 & 171 \\
\hline White spruce & 6,875 & 1,930 & -- & 554 & -- & 729 & 600 \\
\hline Black spruce & 2,338 & 222 & 29 & 99 & 19 & 637 & 276 \\
\hline Balsam fir & 11,877 & 1,685 & -- & 1,224 & -13 & 2,847 & 2,340 \\
\hline Hemlock & 466 & 103 & -- & 43 & -- & 10 & 228 \\
\hline Tamarack & 796 & -61 & 22 & 148 & 49 & 38 & 133 \\
\hline Northern white-cedar & 3,560 & 1,058 & -- & 385 & -- & 279 & 938 \\
\hline Other softwoods & 16 & -- & -- & -- & -- & -- & 5 \\
\hline Total & 49,537 & 6,255 & 191 & 8,193 & 4,001 & 8,897 & 4,885 \\
\hline \multicolumn{8}{|l|}{ Hardwoods } \\
\hline White oak & 1,287 & 2 & 270 & 14 & 181 & 30 & - \\
\hline Select red oak & 10,720 & 163 & 654 & 2,749 & 1,211 & 792 & 258 \\
\hline other red oak & -194 & -- & 14 & -105 & -80 & -18 & -- \\
\hline Select hickory & -- & -- & -- & -- & -- & -- & -- \\
\hline other hickory & 210 & -- & -1 & -- & 11 & -- & -- \\
\hline Basswood & 10,794 & 1,173 & 139 & 806 & 161 & 505 & 846 \\
\hline Beech & $=-$ & $\ddot{-}$ & -- & -- & -- & $\overline{c-}$ & - \\
\hline Yellow birch & 1,174 & 102 & 2 & 47 & 3 & 66 & 92 \\
\hline Hard maple & 18,495 & 4,038 & 115 & 2,880 & 82 & 900 & 2,629 \\
\hline Soft maple & 22,289 & 2,666 & 423 & 3,373 & 377 & 1,590 & 1,382 \\
\hline$E \operatorname{lm}$ & 2,978 & 431 & 146 & 296 & 114 & 115 & 447 \\
\hline Black ash & 8,627 & 842 & 26 & 1,162 & 251 & 1,296 & 309 \\
\hline White a green asn & 3,269 & 217 & 228 & 385 & 30 & 73 & 73 \\
\hline sycamore & -- & -- & -- & -- & -- & -- & -- \\
\hline $\begin{array}{l}\text { Cottonwood } \\
\text { Willow }\end{array}$ & $\overline{-}$ & -- & -- & -- & $\overline{1}$ & -- & -- \\
\hline Hackberry & - & -- & -- & -- & $\begin{array}{c}4 \\
--\end{array}$ & -- & - \\
\hline Balsam poplar & 198 & -- & -- & 19 & - & 144 & -- \\
\hline Bigtooth aspen & 8,194 & 501 & 62 & 1,765 & 973 & 510 & 235 \\
\hline Quaking aspen & 26,291 & 3,117 & 836 & 4,387 & 918 & 3,324 & 1,093 \\
\hline Paper birch & 14,620 & 1,787 & 450 & 3,161 & 523 & 2,412 & 870 \\
\hline Black cherry & 562 & 55 & 17 & -- & 42 & -- & 61 \\
\hline Black walnut & -- & -- & -- & -- & -- & -- & -- \\
\hline Butternut & 170 & -- & 5 & -- & 10 & -- & -- \\
\hline Other hardwoods & 2 & -- & -- & -- & -- & 2 & -- \\
\hline Total & 129,690 & 15,094 & 3,386 & 20,939 & 4,811 & 11,741 & 8,321 \\
\hline Al1 species & 179,227 & 21,349 & 3,577 & 29,132 & 8,812 & 20,638 & 13,206 \\
\hline
\end{tabular}




\begin{tabular}{|c|c|c|c|c|c|c|}
\hline \multirow[b]{2}{*}{ Species group } & \multicolumn{6}{|c|}{ County } \\
\hline & Polk & Price & Rusk & Sawyer & Taylor & Washburn \\
\hline $\begin{array}{l}\text { Softwoods } \\
\text { Jack pine } \\
\text { Red pine } \\
\text { White pine } \\
\text { White spruce } \\
\text { Black spruce } \\
\text { Balsam fir } \\
\text { Hemlock } \\
\text { Tamarack } \\
\text { Northern white-cedar } \\
\text { Other softwoods }\end{array}$ & $\begin{array}{r}537 \\
7 \\
85 \\
28 \\
20 \\
-- \\
-- \\
42 \\
-- \\
-- \\
\end{array}$ & $\begin{array}{r}81 \\
1,098 \\
121 \\
753 \\
239 \\
1,732 \\
-12 \\
53 \\
530 \\
-- \\
\end{array}$ & $\begin{array}{r}-- \\
449 \\
263 \\
87 \\
152 \\
353 \\
8 \\
-13 \\
12 \\
-- \\
\end{array}$ & $\begin{array}{r}89 \\
1,141 \\
892 \\
1,535 \\
284 \\
971 \\
61 \\
105 \\
211 \\
-- \\
\end{array}$ & $\begin{array}{r}-- \\
122 \\
174 \\
653 \\
293 \\
603 \\
38 \\
116 \\
54 \\
-- \\
\end{array}$ & $\begin{array}{r}1,985 \\
472 \\
227 \\
6 \\
68 \\
135 \\
-13 \\
164 \\
93 \\
11 \\
\end{array}$ \\
\hline Total & 719 & 4,595 & 1,311 & 5,289 & 2,053 & 3,148 \\
\hline $\begin{array}{l}\text { Hardwoods } \\
\text { White oak } \\
\text { Select red oak } \\
\text { Other red oak } \\
\text { Select hickory } \\
\text { Other hickory } \\
\text { Basswood } \\
\text { Beech } \\
\text { Yellow birch } \\
\text { Hard maple } \\
\text { Soft maple } \\
\text { Elm } \\
\text { Black ash } \\
\text { White \& green ash } \\
\text { Sycamore } \\
\text { Cottonwood } \\
\text { Willow } \\
\text { Hackberry } \\
\text { Balsam poplar } \\
\text { Bigtooth aspen } \\
\text { Quaking aspen } \\
\text { Paper birch } \\
\text { Black cherry } \\
\text { Black walnut } \\
\text { Butternut } \\
\text { Other hardwoods }\end{array}$ & $\begin{array}{r}350 \\
1,043 \\
-72 \\
-- \\
40 \\
449 \\
-- \\
53 \\
221 \\
592 \\
184 \\
334 \\
414 \\
-- \\
-- \\
-- \\
-- \\
-- \\
457 \\
813 \\
351 \\
38 \\
-- \\
116 \\
-- \\
\end{array}$ & $\begin{array}{r}5 \\
276 \\
-- \\
-- \\
-- \\
926 \\
-- \\
49 \\
1,986 \\
2,738 \\
224 \\
1,296 \\
283 \\
-- \\
-- \\
-- \\
-- \\
-- \\
693 \\
2,379 \\
719 \\
88 \\
-- \\
-- \\
--\end{array}$ & $\begin{array}{r}118 \\
854 \\
10 \\
-- \\
52 \\
1,473 \\
-- \\
106 \\
1,328 \\
1,528 \\
440 \\
678 \\
397 \\
-- \\
-- \\
-- \\
-- \\
-- \\
142 \\
2,900 \\
1,029 \\
149 \\
-- \\
30 \\
-- \\
\end{array}$ & $\begin{array}{r}137 \\
1,291 \\
-- \\
-- \\
37 \\
2,226 \\
-- \\
449 \\
2,171 \\
2,677 \\
532 \\
1,014 \\
593 \\
-- \\
-- \\
-- \\
-- \\
-- \\
831 \\
2,495 \\
1,988 \\
40 \\
-- \\
13 \\
-- \\
\end{array}$ & $\begin{array}{r}4 \\
426 \\
-- \\
-- \\
71 \\
1,302 \\
--- \\
202 \\
1,485 \\
4,093 \\
1 \\
937 \\
417 \\
-- \\
-- \\
-- \\
-- \\
-- \\
944 \\
2,546 \\
468 \\
15 \\
-- \\
4 \\
--- \\
\end{array}$ & $\begin{array}{r}176 \\
1,003 \\
57 \\
-- \\
-- \\
788 \\
-- \\
3 \\
660 \\
850 \\
48 \\
482 \\
159 \\
-- \\
-- \\
-- \\
-- \\
9 \\
1,081 \\
1,483 \\
862 \\
57 \\
-- \\
-8 \\
-- \\
\end{array}$ \\
\hline $\begin{array}{ll} & \text { Total } \\
\text { All } & \text { species } \\
\end{array}$ & $\frac{5,383}{6,102}$ & $\frac{11,662}{16,257}$ & $\frac{11,234}{12,545}$ & $\begin{array}{l}16,494 \\
21,783 \\
\end{array}$ & $\begin{array}{l}12,915 \\
14,968 \\
\end{array}$ & $\begin{array}{r}7,710 \\
10,858 \\
\end{array}$ \\
\hline
\end{tabular}


Table 43.--Net annual growth of sawtimber on commercial forest land by species group and county, Northwest Unit, Wisconsin, 1982

(In thousand board feet) $\underline{1 /}$

\begin{tabular}{|c|c|c|c|c|c|c|c|}
\hline \multirow[b]{2}{*}{ Species group } & \multirow{2}{*}{$\begin{array}{c}\text { All } \\
\text { counties }\end{array}$} & \multicolumn{6}{|c|}{ County } \\
\hline & & Ashl and & Barron & 8ayfield & Burnett & Douglas & Iron \\
\hline \multicolumn{8}{|l|}{ Softwoods } \\
\hline Jack pine & 32,952 & 109 & 612 & 7,739 & 5,283 & 13,949 & -- \\
\hline Red pine & 36,234 & 4,834 & 724 & 11,623 & 709 & 2,237 & 1,165 \\
\hline White pine & 24,449 & 3,211 & 803 & 6,860 & 1,076 & 1,269 & 1,189 \\
\hline White spruce & 25,900 & 7,544 & -- & 3,559 & -- & 3,564 & 3,152 \\
\hline 81 ack spruce & 1,324 & 179 & -- & -- & -- & 158 & 584 \\
\hline 8alsam fir & 40,466 & 8,231 & -- & 4,328 & -- & 10,676 & 6,521 \\
\hline Hemlock & 2,382 & 542 & -- & 245 & -- & 36 & 1,186 \\
\hline Tamarack & 4,123 & 205 & 74 & 878 & 59 & 366 & 1 \\
\hline Northern white-cedar & 18,269 & 6,558 & -- & 1,250 & -- & 1,066 & 4,082 \\
\hline Other softwoods & 99 & - & -- & -- & -- & -- & -- \\
\hline Total & 186,198 & 31,413 & 2,213 & 36,482 & 7,127 & 33,321 & 17,880 \\
\hline \multicolumn{8}{|l|}{ Hardwoods } \\
\hline Whi te oak & 5,331 & 5 & 1,832 & 23 & 1,178 & 9 & -- \\
\hline Select red oak & 43,540 & 1,015 & 3,551 & 9,576 & 5,720 & 2,713 & 225 \\
\hline Other red oak & 5,156 & -- & 59 & 50 & 2,681 & 31 & -- \\
\hline Select hickory & -- & -- & -- & -- & -- & -- & -- \\
\hline Other hickory & 166 & -- & 20 & -- & -- & -- & -- \\
\hline Basswood & 36,516 & 5,943 & 635 & 2,097 & 464 & 824 & 2,842 \\
\hline 8eech & -- & -- & -- & -- & -- & $\overrightarrow{-}$ & -- \\
\hline Yellow birch & 3,607 & 311 & -- & 115 & -- & 146 & 150 \\
\hline Hard maple & 34,046 & 7,341 & 343 & 4,505 & 288 & 2,059 & 3,468 \\
\hline Soft maple & 26,531 & 4,669 & 147 & 1,670 & 1,021 & 1,445 & 626 \\
\hline Elm & 13,119 & 1,765 & 732 & 787 & 440 & 143 & 1,434 \\
\hline 81 ack ash & 15,970 & 1,901 & 1,246 & 2,081 & 1,409 & 2,940 & 523 \\
\hline White \& green ash & 11,871 & 738 & 983 & 374 & 109 & 74 & 334 \\
\hline Sycamore & -- & -- & -- & -- & -- & -- & -- \\
\hline Cottonwood & -- & -- & -- & -- & $\rightarrow-$ & -- & -- \\
\hline Willow & 16 & -- & -- & -- & 16 & -- & - \\
\hline Hackberry & -- & -- & -- & - & -- & -- & $-\overline{1}$ \\
\hline Balsam poplar & 470 & -- & - & 116 & -- & 323 & 31 \\
\hline Bigtooth aspen & 31,043 & 858 & 414 & 7,635 & 3,898 & 3,877 & 302 \\
\hline Quaking aspen & 80,988 & 8,880 & 1,621 & 17,796 & 4,634 & 11,925 & 5,483 \\
\hline Paper birch & 26,972 & 3,953 & 103 & 5,524 & 688 & 5,902 & 2,339 \\
\hline Black cherry & 1,038 & 251 & 22 & -- & 101 & -- & 253 \\
\hline 81 ack walnut & -- & -- & -- & -- & -- & $\cdots$ & -- \\
\hline 8utternut & 723 & -- & 102 & -- & 117 & -- & -- \\
\hline other hardwoods & -- & $\cdots$ & - & -- & -- & -- & - \\
\hline Total & 337,103 & 37,630 & 11,810 & 52,349 & 22,764 & 32,411 & 18,010 \\
\hline All species & 523,301 & 69,043 & 14,023 & 88,831 & 29,891 & 65,732 & 35,890 \\
\hline
\end{tabular}




\begin{tabular}{|c|c|c|c|c|c|c|}
\hline \multirow[b]{2}{*}{ Species group } & \multicolumn{6}{|c|}{ County } \\
\hline & Polk & Price & Rusk & Sawyer & Taylor & Washburn \\
\hline \multicolumn{7}{|l|}{ Softwoods } \\
\hline Jack pine & 1,092 & 520 & $\ldots$ & 922 & -- & 2,726 \\
\hline Red pine & 40 & 4,352 & 1,115 & 6,636 & 881 & 1,918 \\
\hline White pine & 516 & 631 & 1,525 & 5,303 & 1,049 & 1,017 \\
\hline White spruce & 165 & 2,422 & 394 & 3,191 & 1,878 & 31 \\
\hline Black spruce & -- & 104 & -- & 253 & 46 & -- \\
\hline Balsam fir & -- & 2,994 & 1,372 & 3,664 & 2,161 & 519 \\
\hline Hemlock & -- & -22 & 35 & 309 & 111 & -60 \\
\hline Tamarack & 185 & 1,284 & 122 & 163 & 303 & 483 \\
\hline Northern white-cedar & -- & 3,401 & 94 & 1,133 & 300 & 385 \\
\hline Other softwoods & -- & -- & -- & -- & -- & 99 \\
\hline Total & 1,998 & 15,686 & 4,657 & 21,574 & 6,729 & 7,118 \\
\hline \multicolumn{7}{|l|}{ Hardwoods } \\
\hline Whi te oak & 1,365 & 20 & 226 & 137 & 16 & 520 \\
\hline Select red oak & 5,688 & 470 & 3,467 & 5,774 & 1,766 & 3,575 \\
\hline Other red oak & 1,304 & -- & 155 & 615 & -- & 261 \\
\hline Select hickory & -- & -- & -- & -- & -- & -- \\
\hline Other hickory & -- & 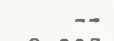 & 34 & -- & 112 & -- \\
\hline Basswood & 1,390 & 3,825 & 5,273 & 6,323 & 6,164 & 736 \\
\hline Beech & -- & -- & -- & -- & -- & -- \\
\hline Yellow birch & -- & -- & 220 & 1,753 & 809 & 103 \\
\hline Hard maple & 276 & 3,735 & 4,217 & 3,458 & 3,787 & 569 \\
\hline Soft maple & 1,436 & 3,289 & 1,948 & 2,703 & 6,087 & 1,490 \\
\hline Elm & 617 & 2,167 & 1,987 & 2,254 & 559 & 234 \\
\hline Black ash & 223 & 946 & 2,043 & 1,743 & 614 & 301 \\
\hline White \& green ash & 1,175 & 1,631 & 1,213 & 2,244 & 2,700 & 296 \\
\hline Sycamore & -- & -- & -- & -- & -- & -- \\
\hline Cottonwood & -- & -- & -- & -- & -- & -- \\
\hline Willow & -- & -- & -- & -- & -- & -- \\
\hline Hackberry & -- & -- & -- & -- & -- & -- \\
\hline Balsam poplar & -- & -- & -- & -- & -- & -- \\
\hline Bigtooth aspen & 1,743 & 1,684 & 688 & 5,641 & 1,892 & 2,411 \\
\hline Quaking aspen & 1,789 & 5,341 & 7,027 & 7,161 & 3,062 & 6,269 \\
\hline Paper birch & 200 & 1,580 & 1,027 & 2,917 & 1,378 & 1,361 \\
\hline Black cherry & -- & 252 & 106 & 53 & -- & -- \\
\hline Black walnut & -- & -- & $-\overline{-}$ & -- & -- & -- \\
\hline Butternut & 108 & -- & 304 & -- & 17 & 75 \\
\hline Other hardwoods & -- & -- & -- & -- & -- & -- \\
\hline Total & 17,314 & 24,940 & 29,935 & 42,776 & 28,963 & 18,201 \\
\hline All species & 19,312 & 40,626 & 34,592 & 64,350 & 35,692 & 25,319 \\
\hline
\end{tabular}

Table 44.--Net annual growth of growing stock on commercial forest 1 and by ownership class and softwoods and hardwoods, Northwest Unit, Wisconsin, 1983

(In thousand cubic feet)

\begin{tabular}{lrrr}
\hline Ownership class & \multicolumn{1}{c}{$\begin{array}{c}\text { Al } \\
\text { species }\end{array}$} & Softwoods & Hardwoods \\
\hline National Forest & 27,716 & 8,210 & 19,506 \\
Miscellaneous federal & 155 & 42 & 113 \\
State & 5,861 & 1,678 & 4,183 \\
County and municipal & 37,864 & 12,279 & 25,585 \\
Indian & 3,913 & 1,436 & 2,477 \\
Forest industry & 18,562 & 5,600 & 12,962 \\
Farmer & 14,926 & 2,881 & 12,045 \\
Misc. private-corp. & 8,148 & 2,488 & 5,660 \\
Misc. private-indiv. & 62,082 & 14,923 & 47,159 \\
All owners & 179,227 & 49,537 & 129,690 \\
\hline
\end{tabular}


Table 45.--Net annual growth of growing stock on commercial forest land by species group and type, Northwest Unit, Wisconsin, 1982

(In thousand cubic feet)

\begin{tabular}{|c|c|c|c|c|c|c|c|c|}
\hline \multirow[b]{2}{*}{ Species group } & \multirow[b]{2}{*}{$\begin{array}{c}\text { All } \\
\text { types }\end{array}$} & \multicolumn{7}{|c|}{ Forest type } \\
\hline & & $\begin{array}{l}\text { Jack } \\
\text { pine }\end{array}$ & $\begin{array}{l}\text { Red } \\
\text { pine }\end{array}$ & $\begin{array}{l}\text { White } \\
\text { pine }\end{array}$ & $\begin{array}{c}\text { Bal sam } \\
\text { fir }\end{array}$ & $\begin{array}{l}\text { White } \\
\text { spruce }\end{array}$ & $\begin{array}{l}\text { Bl ack } \\
\text { spruce }\end{array}$ & $\begin{array}{c}\text { Northern } \\
\text { whi te- } \\
\text { cedar }\end{array}$ \\
\hline \multicolumn{9}{|l|}{ Softwoods } \\
\hline Jack pine & 10,607 & 8,020 & 142 & 23 & -- & -- & -- & -. \\
\hline Red pine & 8,768 & 848 & 6,211 & 182 & 311 & 10 & 16 & -- \\
\hline White pine & 4,234 & 100 & 573 & 1,101 & 176 & 36 & 34 & -13 \\
\hline White spruce & 6,875 & -- & 26 & 61 & 705 & 3,373 & 25 & 55 \\
\hline Black spruce & 2,338 & 9 & -- & 33 & 166 & 1 & 1,246 & 87 \\
\hline Balsam fir & 11,877 & 7 & 48 & 73 & 2,190 & 69 & 120 & 685 \\
\hline Heml ock & 466 & -- & -- & -- & -20 & -- & 24 & 11 \\
\hline Tamarack & 796 & -- & -- & -19 & 69 & -- & -84 & \\
\hline Northern white-cedar & 3,560 & -- & 20 & -- & 586 & 44 & 159 & 1,855 \\
\hline Other softwoods & & -- & -- & 11 & -- & -- & - & - \\
\hline Total & 49,537 & 8,984 & 7,020 & 1,465 & 4,183 & 3,533 & 1,540 & 2,799 \\
\hline \multicolumn{9}{|l|}{ Hardwoods } \\
\hline White oak & 1,287 & -- & -- & -7 & 1 & -- & -- & -- \\
\hline Select red oak & 10,720 & 90 & 90 & 13 & 3 & -- & 16 & -- \\
\hline other red oak & -194 & 26 & -- & -23 & -- & -- & -- & -- \\
\hline Select hickory & -- & -- & -- & -- & -- & -- & -- & -- \\
\hline Other hickory & 210 & -- & -- & -- & -- & -- & -- & -- \\
\hline Basswood & 10,794 & 2 & -- & 14 & -- & -- & - & -- \\
\hline Beech & -- & -- & -- & -- & -- & -- & -- & -- \\
\hline Yellow birch & 1,174 & -- & -- & -- & -34 & -- & 1 & -38 \\
\hline Hard maple & 18,495 & -- & 32 & -- & 34 & 2 & 6 & -- \\
\hline Soft maple & 22,289 & -- & 118 & 34 & 222 & 13 & 22 & 2 \\
\hline Elm & 2,978 & -- & 3 & -4 & 17 & -- & -- & -- \\
\hline Black ash & 8,627 & -- & -- & -- & 566 & 3 & -- & 632 \\
\hline White \& green ash & 3,269 & -- & 5 & -- & 6 & 14 & -- & -- \\
\hline Sycamore & - & -- & -- & -- & -- & -- & -- & -- \\
\hline Cottonwood & -- & -- & -- & -- & -- & -- & -- & -- \\
\hline Willow & 4 & -- & -- & -- & -- & -- & -- & -- \\
\hline Hackberry & -- & -- & -- & -- & -- & -- & -- & -- \\
\hline Bal sam poplar & 198 & -- & -- & -- & 3 & -- & -- & -- \\
\hline Bigtooth aspen & 8,194 & 236 & 50 & 63 & 12 & 4 & -7 & -- \\
\hline Quaking aspen & 26,291 & 173 & 107 & 313 & -41 & 3 & 2 & 29 \\
\hline Paper birch & 14,620 & 38 & 94 & 56 & 214 & 7 & 30 & 77 \\
\hline Black cherry & 562 & -- & -- & -- & 2 & -- & -- & -- \\
\hline Bl ack walnut & -- & -- & -- & -- & -- & -- & -- & -- \\
\hline Butternut & 170 & -- & -- & -- & -- & -- & -- & -- \\
\hline Other hardwoods & 2 & -- & -- & -- & -- & -- & -- & -- \\
\hline Total & 129,690 & 565 & 499 & 459 & 1,005 & 46 & 70 & 702 \\
\hline All species & 179,227 & 9,549 & 7,519 & 1,924 & 5,188 & 3,579 & 1,610 & 3,501 \\
\hline
\end{tabular}


(Table 45 continued)

\begin{tabular}{|c|c|c|c|c|c|c|c|c|}
\hline \multirow[b]{2}{*}{ Species group } & \multicolumn{8}{|c|}{ Forest type } \\
\hline & Tamarack & $\begin{array}{c}\text { Oak- } \\
\text { nickory }\end{array}$ & $\begin{array}{l}\text { Elm-ash- } \\
\text { soft maple }\end{array}$ & $\begin{array}{l}\text { Maple- } \\
\text { birch }\end{array}$ & Aspen & $\begin{array}{l}\text { Paper } \\
\text { birch }\end{array}$ & Exotic & $\begin{array}{c}\text { Non- } \\
\text { stocked }\end{array}$ \\
\hline \multicolumn{9}{|l|}{ Softwoods } \\
\hline Jack pine & 17 & 1,465 & 11 & 21 & 815 & 24 & -- & 69 \\
\hline Red pine & 7 & 240 & 7 & 160 & 706 & 70 & -- & -- \\
\hline White pine & 117 & 237 & 156 & 779 & 801 & 127 & -- & 10 \\
\hline White spruce & 19 & -- & 226 & 597 & 1,438 & 342 & -- & 8 \\
\hline Black spruce & 378 & -- & 30 & 78 & 215 & 95 & -- & -- \\
\hline Bal sam fir & 543 & 31 & 1,246 & 2,016 & 3,924 & 925 & - & - \\
\hline Heml ock & 2 & 9 & 45 & 338 & 45 & 12 & -- & -- \\
\hline Tamarack & 507 & -1 & 118 & -25 & 83 & 15 & -- & 14 \\
\hline Northern white-cedar & 11 & -- & 318 & 406 & 125 & 36 & -- & -- \\
\hline Other softwoods & -- & -- & -- & 5 & -- & -- & -- & -- \\
\hline Total & 1,601 & 1,981 & 2,157 & 4,375 & 8,152 & 1,646 & -- & 101 \\
\hline \multicolumn{9}{|l|}{ Hardwoods } \\
\hline White oak & -- & 722 & 56 & 224 & 253 & 30 & -- & 8 \\
\hline Select red oak & -- & 5,195 & 123 & 2,857 & 1,839 & 494 & -- & -- \\
\hline other red oak & -- & -88 & -14 & 16 & -77 & 3 & -- & -37 \\
\hline Select hickory & -- & -- & -- & -- & -- & -- & -- & -- \\
\hline Other hickory & -- & 22 & 4 & 172 & 12 & -- & -- & -- \\
\hline Basswood & -- & 383 & 415 & 9,187 & 665 & 128 & -- & -- \\
\hline Beech & -- & -- & -- & -- & $\overline{-1}$ & -- & -- & -- \\
\hline Yellow birch & -- & 2 & 84 & 1,053 & 105 & 1 & -- & -- \\
\hline Hard maple & 5 & 183 & 506 & 16,446 & 929 & 285 & -- & 67 \\
\hline Soft maple & 160 & 772 & 2,658 & 11,621 & 5,360 & 1,304 & -- & 3 \\
\hline Elm & -- & -7 & 974 & 1,507 & 438 & 50 & -- & -- \\
\hline Black ash & -- & 20 & 4,356 & 1,816 & 1,087 & 130 & -- & 17 \\
\hline White \& green ash & -- & 159 & 192 & 2,593 & 216 & 84 & -- & -- \\
\hline Sycamore & -- & -- & -- & -- & -- & -- & -- & -- \\
\hline Cottonwood & -- & -- & -- & -- & -- & -- & -- & -- \\
\hline Willow & -- & -- & 4 & -- & -- & -- & $\rightarrow$ & -- \\
\hline Hackberry & -- & -- & -- & $-\bar{c}$ & $\overline{-}$ & -- & - & - \\
\hline Bal sam poplar & -- & -1 & 26 & -5 & 179 & -4 & -- & -- \\
\hline Bigtooth aspen & 331 & 409 & 21 & 987 & 5,937 & 151 & -- & $\overrightarrow{7}$ \\
\hline Quaking aspen & 72 & 379 & 567 & 2,542 & 21,816 & 259 & -- & 70 \\
\hline Paper birch & 54 & 934 & 251 & 2,080 & 5,411 & 5,313 & -- & 61 \\
\hline Black cherry & 1 & -15 & 5 & 324 & 214 & 31 & -- & -- \\
\hline Black walnut & -- & -- & -- & -- & -- & -- & -- & -- \\
\hline Butternut & -- & 24 & -- & 155 & -9 & -- & -- & -- \\
\hline Other hardwoods & -- & -- & 2 & - & -- & -- & -- & -- \\
\hline Total & 623 & 9,093 & 10,230 & 53,575 & 44,375 & 8,259 & -- & 189 \\
\hline Al1 species & 2,224 & 11,074 & 12,387 & 57,950 & 52,527 & 9,905 & -- & 290 \\
\hline
\end{tabular}


Table 46.--Net annual growth of sawtimber on commercial forest land by species group and type, Northwest Unit, Wisconsin, 1982

(In thousand board feet) 1 !

\begin{tabular}{|c|c|c|c|c|c|c|c|c|}
\hline \multirow[b]{2}{*}{ Species group } & \multirow[b]{2}{*}{$\begin{array}{l}\text { All } \\
\text { types }\end{array}$} & \multicolumn{7}{|c|}{ Forest type } \\
\hline & & $\begin{array}{l}\text { Jack } \\
\text { pine }\end{array}$ & $\begin{array}{l}\text { Red } \\
\text { pine }\end{array}$ & $\begin{array}{l}\text { White } \\
\text { pine }\end{array}$ & $\begin{array}{l}\text { Bal sam } \\
\text { fir }\end{array}$ & $\begin{array}{l}\text { White } \\
\text { spruce }\end{array}$ & $\begin{array}{l}\text { Bl ack } \\
\text { spruce }\end{array}$ & $\begin{array}{c}\text { Northern } \\
\text { whi te-cedar }\end{array}$ \\
\hline \multicolumn{9}{|l|}{ Softwoods } \\
\hline Jack pine & 32,952 & 21,534 & 1,902 & 51 & -- & -- & -- & -- \\
\hline Red pine & 36,234 & 2,398 & 24,321 & 1,112 & 1,517 & -- & 721 & -- \\
\hline White pine & 24,449 & 798 & 2,951 & 5,780 & 997 & 216 & 113 & -118 \\
\hline White spruce & 25,900 & -- & 124 & 341 & 3,634 & 10,167 & 120 & 332 \\
\hline 81 ack spruce & 1,324 & -- & -- & -- & 392 & 59 & 411 & 165 \\
\hline Balsam fir & 40,466 & -- & 627 & 445 & 16,042 & 210 & 124 & 54 \\
\hline Heml ock & 2,382 & -- & -- & -- & -107 & -- & 132 & 46 \\
\hline Tamarack & 4,123 & -- & -- & 70 & 294 & -- & 1 & 427 \\
\hline Northern white-cedar & 18,269 & -- & 58 & -- & 2,612 & -- & 584 & 10,907 \\
\hline Other softwoods & 99 & -- & -- & 99 & -- & -- & -- & -- \\
\hline Total & 186,198 & 24,730 & 29,983 & 7,898 & 25,381 & 10,652 & 2,206 & 11,813 \\
\hline \multicolumn{9}{|l|}{ Hardwoods } \\
\hline White oak & 5,331 & -- & -- & 3 & -- & -- & -- & -- \\
\hline Select red oak & 43,540 & 137 & 213 & -- & 16 & -- & 13 & -- \\
\hline Other red oak & 5,156 & 643 & -- & 11 & -- & -- & -3 & -- \\
\hline Select hickory & -- & -- & -- & -- & -- & -- & -- & -- \\
\hline Other hickory & 166 & -- & - & -- & -- & $\cdots$ & - & -- \\
\hline Basswood & 36,516 & -- & -- & 20 & -- & -- & -- & -- \\
\hline Beech & -- & -- & -- & -- & -- & -- & -- & 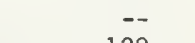 \\
\hline Yellow birch & 3,607 & -- & -- & -- & -151 & -- & 5 & -128 \\
\hline Hard maple & 34,046 & -- & -- & -- & 73 & -- & -- & -- \\
\hline Soft maple & 26,531 & -- & -- & -- & 123 & 95 & -- & 62 \\
\hline Elm & 13,119 & -- & -- & 9 & 137 & -- & -- & -- \\
\hline Black ash & 15,970 & -- & -- & -- & 1,544 & 11 & -- & 10 \\
\hline White \& green ash & 11,871 & -- & -- & -- & -- & -- & -- & -- \\
\hline Sycamore & -- & -- & -- & -- & -- & -- & -- & $\rightarrow$ \\
\hline Cottonwood & -- & - & - & -- & -- & -- & - & -- \\
\hline Willow & 16 & -- & -- & -- & -- & -- & -- & -- \\
\hline Hackberry & -- & -- & -- & -- & -- & -- & -- & -- \\
\hline Bal sam poplar & 470 & -- & -- & -- & - & - & -- & -- \\
\hline Bigtooth aspen & 31,043 & -- & 115 & 250 & -- & -- & -15 & -6 \\
\hline Quaking aspen & 80,988 & 159 & 618 & 912 & 1,941 & 674 & 48 & 264 \\
\hline Paper birch & 26,972 & -- & 414 & 49 & 2,354 & -- & 13 & -- \\
\hline Black cherry & 1,038 & -- & -- & -- & 53 & - & -- & -- \\
\hline Bl ack wal nut & -- & -- & -- & -- & -- & -- & -- & -- \\
\hline Butternut & 723 & -- & -- & -- & -- & -- & -- & -- \\
\hline Other hardwoods & -- & $=-$ & -- & -- & -- & -- & -- & -- \\
\hline Total & 337,103 & 939 & 1,360 & 1,254 & 6,090 & 780 & 61 & 202 \\
\hline All species & 523,301 & 25,669 & 31,343 & 9,152 & 31,471 & 11,432 & 2,267 & 12,015 \\
\hline
\end{tabular}




\begin{tabular}{|c|c|c|c|c|c|c|c|c|}
\hline \multirow[b]{2}{*}{ Species group } & \multicolumn{8}{|c|}{ Forest type } \\
\hline & Tamarack & $\begin{array}{c}\text { Oak- } \\
\text { hickory }\end{array}$ & $\begin{array}{l}\text { Elm-ash- } \\
\text { soft maple }\end{array}$ & $\begin{array}{l}\text { Maple- } \\
\text { birch }\end{array}$ & Aspen & $\begin{array}{l}\text { Paper } \\
\text { birch }\end{array}$ & Exotic & $\begin{array}{c}\text { Non- } \\
\text { stocked }\end{array}$ \\
\hline \multicolumn{9}{|l|}{ Softwoods } \\
\hline Jack pine & -- & 5,759 & 75 & 130 & 3,243 & 202 & -- & 56 \\
\hline Red pine & 38 & 529 & 43 & 1,065 & 4,116 & 374 & -- & -- \\
\hline White pine & 808 & 1,369 & 1,211 & 4,642 & 4,601 & 757 & -- & 324 \\
\hline White spruce & 65 & -- & 1,343 & 3,624 & 4,686 & 1,419 & -- & 45 \\
\hline Black spruce & 76 & -- & 105 & -13 & 110 & 19 & -- & -- \\
\hline Balsam fir & 93 & 35 & 3,554 & 6,201 & 10,986 & 2,095 & -- & -- \\
\hline Hemlock & 8 & 50 & 245 & 1,739 & 215 & 54 & -- & -- \\
\hline Tamarack & 1,034 & -- & 844 & -8 & 736 & 99 & -- & 626 \\
\hline Northern white-cedar & - & -- & 2,015 & 1,626 & 388 & 79 & -- & -- \\
\hline Other softwoods & -- & -- & -- & -- & -- & - & -- & -- \\
\hline Total & 2,122 & 7,742 & 9,435 & 19,006 & 29,081 & 5,098 & -- & 1,051 \\
\hline \multicolumn{9}{|l|}{ Hardwoods } \\
\hline White oak & -- & 2,561 & 208 & 1,713 & 760 & 74 & -- & 12 \\
\hline Select red oak & -- & 20,309 & 674 & 14,712 & 5,470 & 1,996 & -- & - \\
\hline Other red oak & -- & 1,790 & 675 & 390 & 1,551 & 82 & -- & 17 \\
\hline Select hickory & -- & -- & -- & -- & - & -- & -- & -- \\
\hline other hickory & -- & 7 & -- & 159 & -- & -- & -- & -- \\
\hline Basswood & -- & 462 & 1,042 & 34,317 & 556 & 119 & -- & -- \\
\hline Beech & -- & -- & -- & -- & -- & -- & -- & -- \\
\hline Yellow birch & -- & -- & 565 & 3,349 & -3 & -30 & -- & -- \\
\hline Hard maple & -- & 215 & 366 & 32,878 & 401 & 113 & -- & -- \\
\hline Soft maple & 36 & 595 & 5,984 & 17,424 & 1,988 & 224 & -- & -- \\
\hline Elm & -- & -156 & 3,790 & 8,294 & 841 & 204 & -- & -- \\
\hline Black ash & -- & 194 & 8,733 & 4,115 & 1,169 & 194 & -- & -- \\
\hline White \& green ash & -- & 975 & 1,284 & 9,242 & 251 & 119 & -- & -- \\
\hline Sycamore & -- & -- & -- & -- & -- & -- & -- & -- \\
\hline Cottonwood & -- & -- & -- & -- & -- & -- & -- & -- \\
\hline Willow & -- & -- & 16 & -- & -- & -- & -- & -- \\
\hline Hackberry & -- & -- & -- & -- & -- & -- & -- & -- \\
\hline Bal sam poplar & -- & -- & 27 & -34 & 499 & -22 & -- & -- \\
\hline Bigtooth aspen & 21 & 808 & 102 & 2,402 & 26,437 & 929 & -- & -- \\
\hline Quaking aspen & 90 & 2,666 & 1,334 & 14,708 & 53,781 & 3,207 & -- & 586 \\
\hline Paper birch & 108 & 2,111 & 1,646 & 6,374 & 9,922 & 3,981 & -- & -- \\
\hline Bl ack cherry & - & - & - & 778 & 101 & 106 & -- & -- \\
\hline Black walnut & - & -- & -- & -- & -- & -- & -- & -- \\
\hline Butternut & -- & 229 & -- & 494 & -- & -- & -- & -- \\
\hline Other hardwoods & -- & -- & -- & -- & -- & -- & -- & -- \\
\hline Total & 255 & 32,766 & 26,446 & 151,315 & 103,724 & 11,296 & -- & 615 \\
\hline All species & 2,377 & 40,508 & 35,881 & 170,321 & 132,805 & 16,394 & -- & 1,666 \\
\hline
\end{tabular}




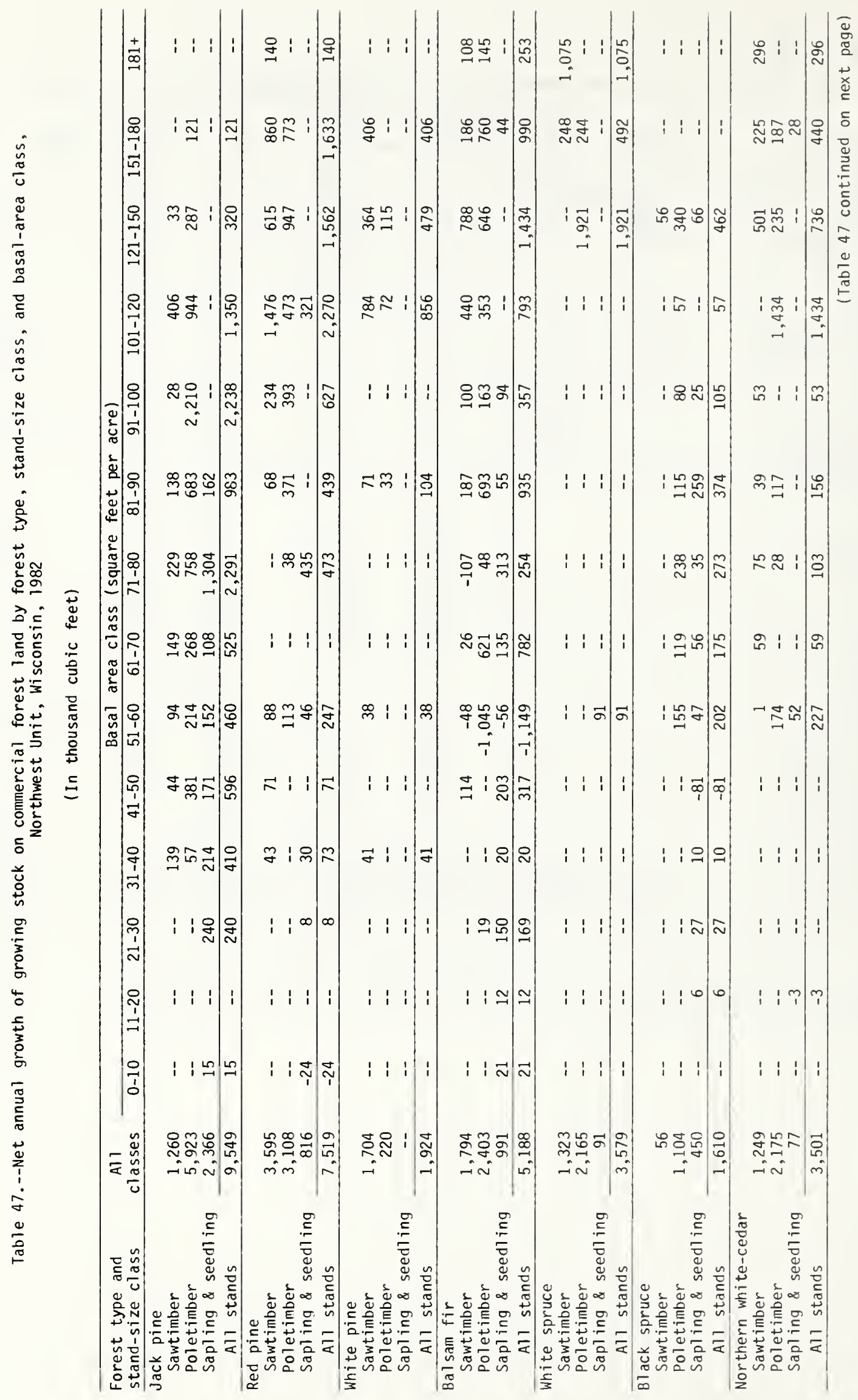




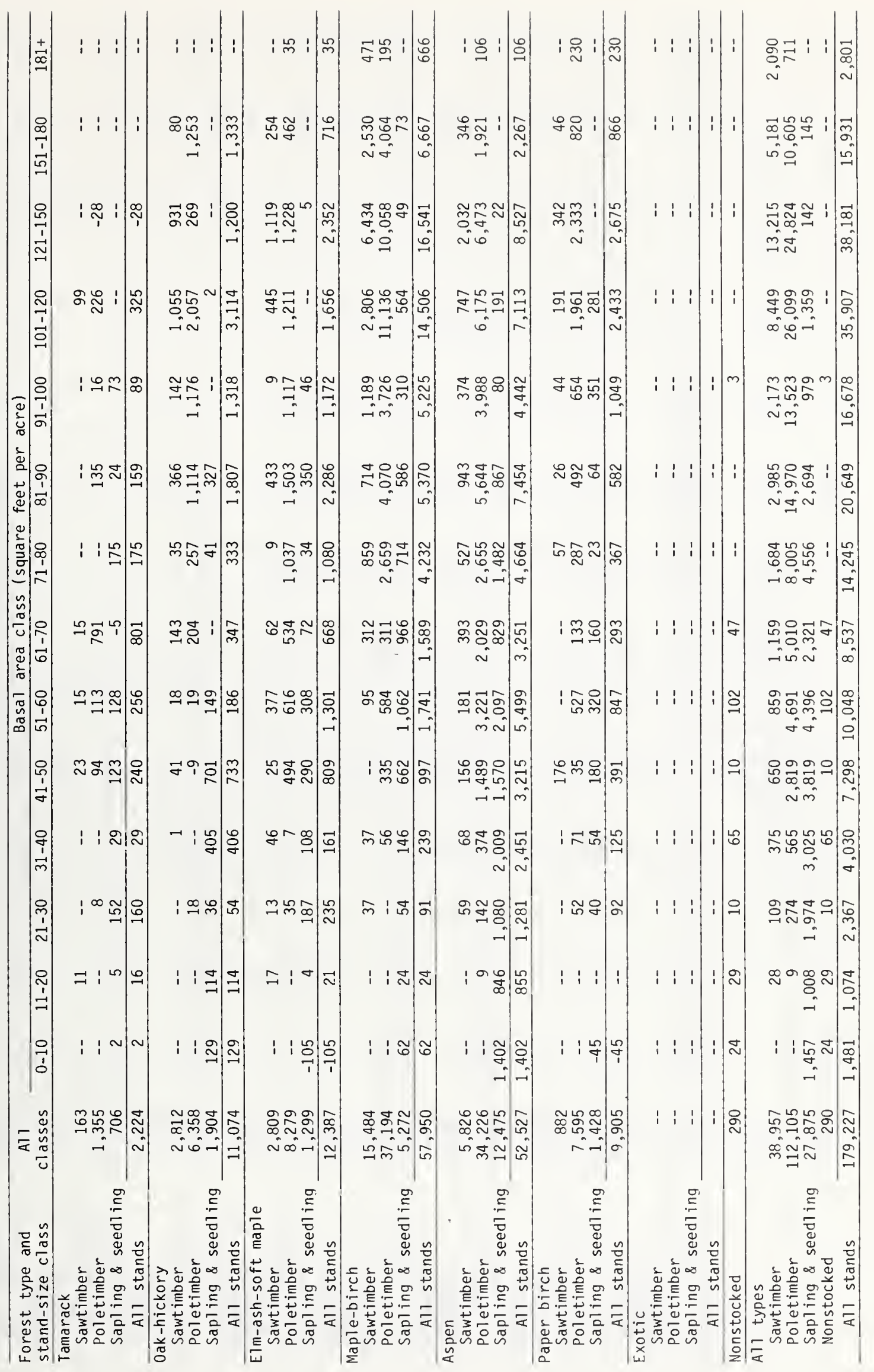




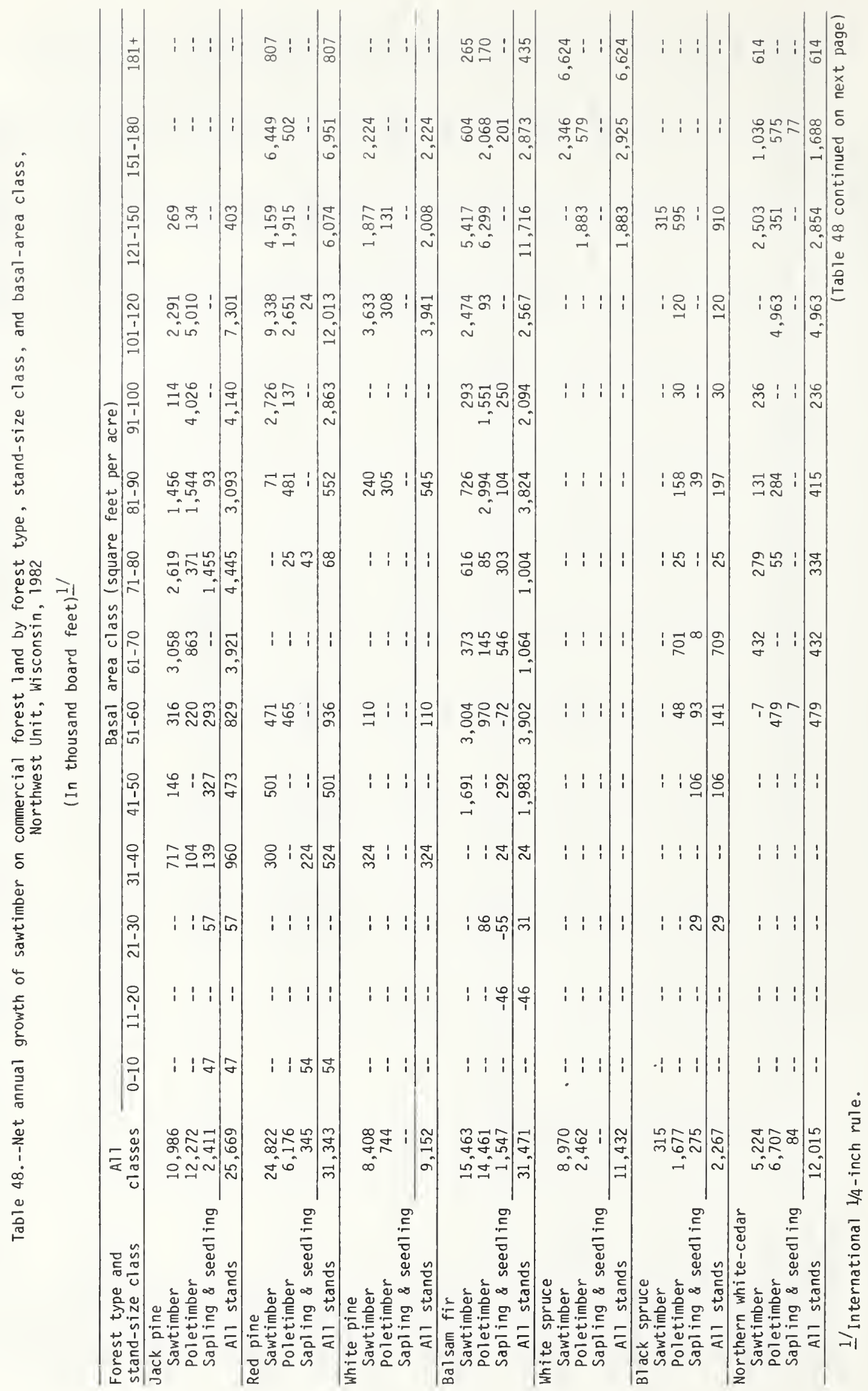




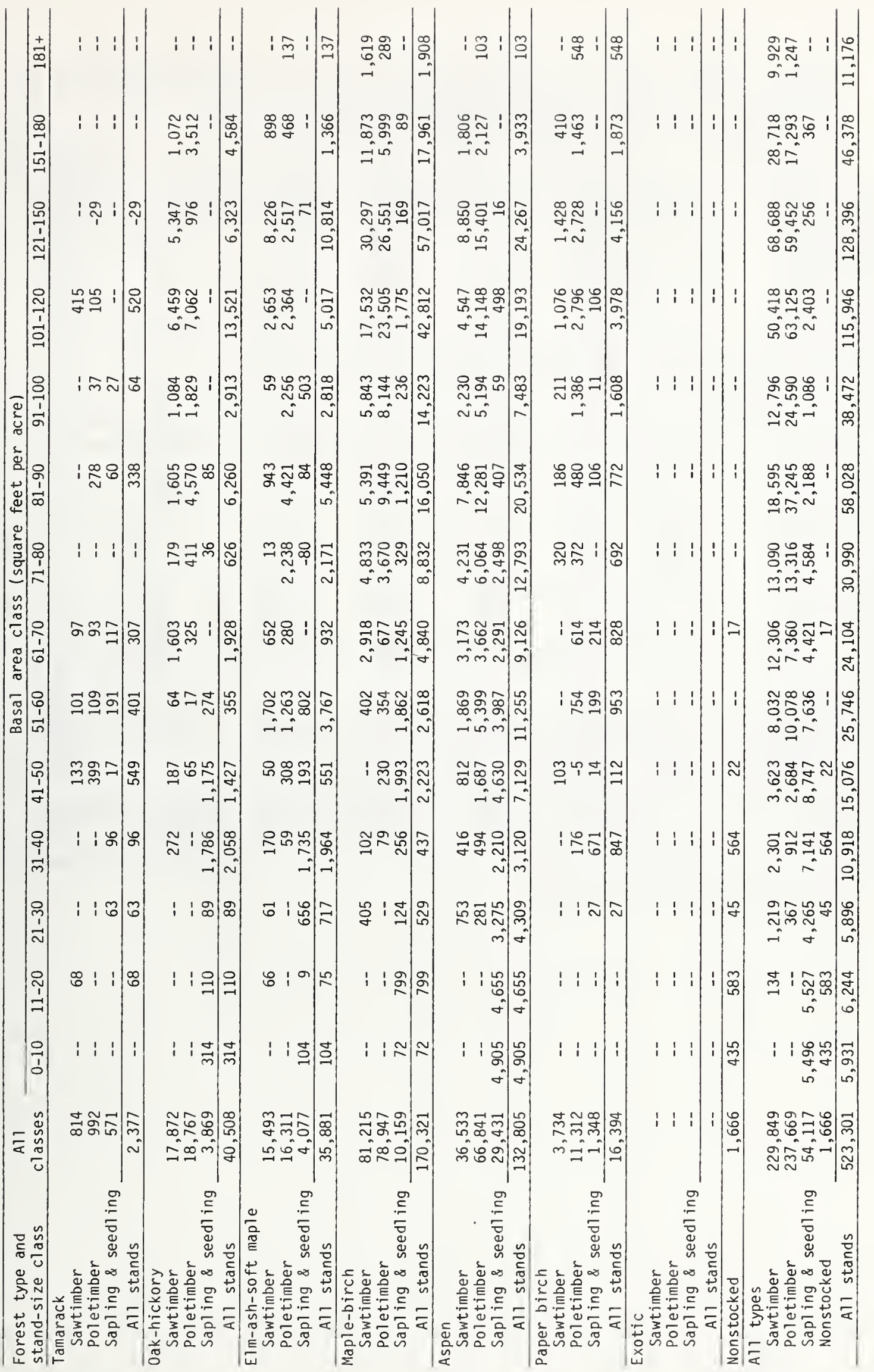


Table 49.--Current annual growing-stock removals on commercial forest land by species group and county, Northwest Unit, Wisconsin, 1982

(In thousand cubic feet)

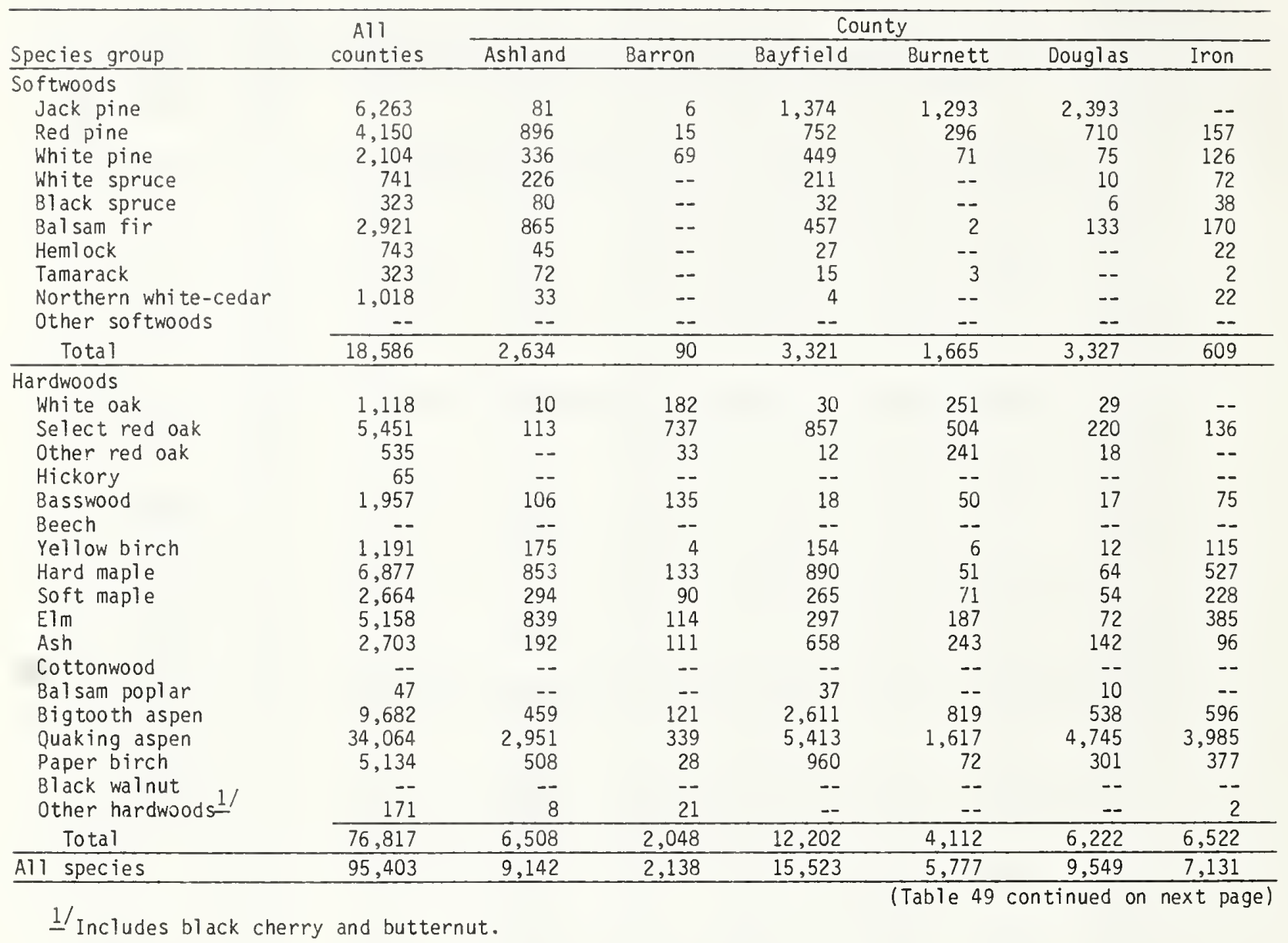


(Table 49 continued)

\begin{tabular}{|c|c|c|c|c|c|c|}
\hline \multirow[b]{2}{*}{ Species group } & \multicolumn{6}{|c|}{ County } \\
\hline & Polk & Price & Rusk & Sawyer & Taylor & Washburn \\
\hline \multicolumn{7}{|l|}{ Softwoods } \\
\hline Jack pine & 125 & 91 & -- & 215 & -- & 685 \\
\hline Red pine & 14 & 216 & 132 & 380 & 241 & 341 \\
\hline White pine & 19 & 189 & 152 & 282 & 224 & 112 \\
\hline White spruce & -- & 85 & 1 & 78 & 23 & 35 \\
\hline Black spruce & -- & 62 & -- & 53 & 18 & 34 \\
\hline Balsam fir & -- & 477 & -- & 411 & 246 & 160 \\
\hline Hemlock & -- & 58 & 15 & 497 & 79 & -- \\
\hline Tamarack & -- & 120 & 7 & 72 & 30 & 2 \\
\hline Northern white-cedar & -- & 897 & -- & 31 & 31 & -- \\
\hline Other softwoods & -- & $\cdots$ & -- & -- & -- & -- \\
\hline Total & 158 & 2,195 & 307 & 2,019 & 892 & 1,369 \\
\hline \multicolumn{7}{|l|}{ Hardwoods } \\
\hline White oak & 360 & 22 & 90 & 32 & 41 & 71 \\
\hline Select red oak & 604 & 362 & 860 & 366 & 348 & 344 \\
\hline Other red oak & 153 & -- & 28 & 6 & -- & 44 \\
\hline Hickory & 2 & -- & 30 & -- & 33 & -- \\
\hline Basswood & 113 & 609 & 399 & 222 & 197 & 16 \\
\hline Beech & -- & -- & -- & -- & -- & -- \\
\hline Yellow birch & 1 & 234 & 94 & 195 & 184 & 17 \\
\hline Hard maple & 64 & 1,799 & 668 & 843 & 834 & 151 \\
\hline Soft maple & 17 & 602 & 307 & 268 & 386 & 82 \\
\hline Elm & 119 & 1,637 & 545 & 234 & 689 & 40 \\
\hline Ash & 59 & 419 & 272 & 230 & 250 & 31 \\
\hline Cottonwood & -- & -- & -- & -- & -- & -- \\
\hline Balsam poplar & -- & -- & -- & -- & -- & -- \\
\hline Bigtooth aspen & 62 & 697 & 306 & 1,767 & 634 & 1,072 \\
\hline Quaking aspen & 153 & 2,893 & 3,268 & 4,668 & 2,058 & 1,974 \\
\hline Paper birch & 48 & 949 & 471 & 804 & 382 & 234 \\
\hline Black walnut & -- & -- & -- & -- & -- & -- \\
\hline Other hardwoods & 2 & 75 & 20 & 26 & 14 & 3 \\
\hline Total & 1,757 & 10,298 & 7,358 & 9,661 & 6,050 & 4,079 \\
\hline All species & 1,915 & 12,493 & 7,665 & 11,680 & 6,942 & 5,448 \\
\hline
\end{tabular}

$1 /$ Includes black cherry and butternut. 
Table 50.--Current annual sawtimber removals on commercial forest 1 and by species group and county, Northwest Unit, Wisconsin, 1982

(In thousand board feet) 1 /

\begin{tabular}{|c|c|c|c|c|c|c|c|}
\hline \multirow[b]{2}{*}{ Species group } & \multirow{2}{*}{$\begin{array}{c}\text { All } \\
\text { counties }\end{array}$} & \multicolumn{6}{|c|}{ County } \\
\hline & & Ashl and & Barron & Bayfield & Burnett & Douglas & Iron \\
\hline \multicolumn{8}{|l|}{ Softwoods } \\
\hline Jack pine & 9,315 & 137 & 9 & 2,782 & 1,645 & 2,952 & -- \\
\hline Red pine & 12,770 & 2,261 & 66 & 3,018 & 883 & 1,489 & 691 \\
\hline White pine & 9,788 & 1,570 & 359 & 2,185 & 248 & 173 & 572 \\
\hline White spruce & 2,656 & 618 & -- & 897 & -- & 52 & 371 \\
\hline Black spruce & 154 & 38 & -- & -- & -- & 6 & 40 \\
\hline Balsam fir & 6,753 & 1,701 & -- & 1,562 & -- & 458 & 415 \\
\hline Hemlock & 643 & 88 & -- & 51 & -- & -- & 47 \\
\hline Tamarack & 386 & 100 & -- & 7 & 7 & -- & 3 \\
\hline Northern white-cedar & 1,293 & 49 & -- & 7 & -- & -- & 38 \\
\hline Other softwoods & -- & $=-$ & -- & -- & -- & $=-$ & -- \\
\hline Total & 43,758 & 6,562 & 434 & 10,509 & 2,783 & 5,130 & 2,177 \\
\hline \multicolumn{8}{|l|}{ Hardwoods } \\
\hline White oak & 3,934 & 30 & 822 & 95 & 792 & 33 & -- \\
\hline Select red oak & 20,781 & 376 & 3,258 & 2,753 & 1,583 & 671 & 549 \\
\hline other red oak & 2,243 & -- & 104 & 6 & 1,014 & 30 & -- \\
\hline Hickory & 178 & -- & 1 & -- & -- & 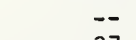 & -- \\
\hline Basswood & 7,003 & 463 & 416 & 92 & 53 & 37 & 280 \\
\hline Beech & & -- & -- & -- & -- & -- & -- \\
\hline Yellow birch & 2,431 & 419 & $\overline{-}$ & 295 & $\overline{-}$ & 41 & 329 \\
\hline Hard maple & 21,711 & 2,957 & 671 & 2,245 & 176 & 222 & 1,888 \\
\hline Soft maple & 6,226 & 606 & 154 & 560 & 73 & 67 & 413 \\
\hline Elm & 16,307 & 3,115 & 518 & 513 & 223 & 22 & 1,370 \\
\hline Ash & 4,964 & 435 & 409 & 171 & 92 & 67 & 243 \\
\hline Cottonwood & -- & -- & -- & $-\overline{-}$ & -- & $\overline{-}$ & -- \\
\hline Balsam poplar & & -- & -- & 34 & -- & 17 & -- \\
\hline Bigtooth aspen & 30,821 & 996 & 729 & 7,810 & 2,185 & 1,921 & 1,541 \\
\hline Quaking aspen & 83,522 & 7,080 & 980 & 13,225 & 3,534 & 11,008 & 12,207 \\
\hline Paper birch & 5,413 & 348 & 47 & 1,124 & 203 & 283 & 522 \\
\hline Black walnut $2 /$ & $\overline{--}$ & $-\overline{1}$ & 81 & -- & $-\overline{2}$ & -- & - \\
\hline Other hardwoods $\leq$ & 225 & 19 & 81 & -- & 2 & -- & 4 \\
\hline Total & 205,810 & 16,844 & 8,190 & 28,923 & 9,930 & 14,419 & 19,346 \\
\hline All species & 249,568 & 23,406 & 8,624 & 39,432 & 12,713 & 19,549 & 21,523 \\
\hline
\end{tabular}


(Table 50 continued)

\begin{tabular}{|c|c|c|c|c|c|c|}
\hline \multirow[b]{2}{*}{ Species group } & \multicolumn{6}{|c|}{ County } \\
\hline & Polk & Price & Rusk & Sawyer & Taylor & Wa shburn \\
\hline \multicolumn{7}{|l|}{ Softwoods } \\
\hline Jack pine & 160 & 123 & -- & 421 & -- & 1,086 \\
\hline Red pine & 66 & 598 & 528 & 1,028 & 966 & 1,176 \\
\hline White pine & 102 & 980 & 775 & 1,363 & 997 & 464 \\
\hline White spruce & -- & 220 & 4 & 206 & 57 & 231 \\
\hline Black spruce & -- & 15 & -- & 51 & 4 & -- \\
\hline Balsam fir & -- & 909 & 2 & 820 & 437 & 449 \\
\hline Hemlock & -- & 144 & 31 & 103 & 179 & -- \\
\hline Tamarack & -- & 136 & 11 & 79 & 39 & 4 \\
\hline Northern white-cedar & -- & 1,120 & -- & 29 & 50 & -- \\
\hline Other softwoods & -- & - & -- & - & -- & -- \\
\hline Tota 1 & 328 & 4,245 & 1,351 & 4,100 & 2,729 & 3,410 \\
\hline \multicolumn{7}{|l|}{ Hardwoods } \\
\hline White oak & 1,418 & 61 & 258 & 107 & 141 & 177 \\
\hline Select red oak & 2,804 & 1,259 & 3,453 & 1,623 & 1,507 & 945 \\
\hline other red oak & 809 & -- & 165 & 28 & - & 87 \\
\hline Hickory & -- & -- & 68 & -- & 109 & -- \\
\hline Basswood & 548 & 2,279 & 1,521 & 615 & 614 & 85 \\
\hline Beech & -- & -- & -- & -- & -- & -- \\
\hline Yellow birch & -- & 459 & 218 & 191 & 425 & 54 \\
\hline Hard maple & 341 & 4,913 & 2,483 & 2,501 & 2,846 & 468 \\
\hline Soft maple & 83 & 1,641 & 785 & 581 & 1,054 & 209 \\
\hline Elm & 554 & 4,823 & 2,035 & 791 & 2,219 & 124 \\
\hline Ash & 284 & 1,122 & 721 & 648 & 719 & 53 \\
\hline Cottonwood & -- & - & - & - & -- & -- \\
\hline Bal sam poplar & -- & -- & - & -- & -- & -- \\
\hline Bigtooth aspen & 326 & 1,653 & 1,412 & 5,986 & 2,891 & 3,371 \\
\hline Quaking aspen & 682 & 8,194 & 8,653 & 10,153 & 4,044 & 3,762 \\
\hline Paper birch & 37 & 760 & 265 & 985 & 547 & 292 \\
\hline Black walnut & -- & -- & -- & -- & -- & -- \\
\hline Other hardwoods 27 & 8 & 23 & 26 & 39 & 17 & 6 \\
\hline Total & 7,894 & 27,187 & 22,063 & 24,248 & 17,133 & 9,633 \\
\hline All species & 8,222 & 31,432 & 23,414 & 28,348 & 19,862 & 13,043 \\
\hline
\end{tabular}

2/ Includes black cherry and butternut. 
Table 51.--Average annual growing-stock removals on commercial forest land by species group and county, Northwest Unit, Wisconsin, 1967-1982

(In thousand cubic feet per year)

\begin{tabular}{|c|c|c|c|c|c|c|c|}
\hline \multirow[b]{2}{*}{ Species group } & \multirow{2}{*}{$\begin{array}{c}\text { Al } 1 \\
\text { counties }\end{array}$} & \multicolumn{6}{|c|}{ County } \\
\hline & & Ashl and & Barron & Bayfield & Burnett & Douglas & Iron \\
\hline \multicolumn{8}{|l|}{ Softwoods } \\
\hline Jack pine & 7,009 & 6 & -- & 1,138 & 2,286 & 2,083 & -- \\
\hline Red pine & 335 & 3 & -- & 162 & -- & -- & 91 \\
\hline White pine & 1,261 & 7 & -- & 259 & 80 & 43 & -- \\
\hline White spruce & 964 & 613 & -- & 156 & -- & -- & 102 \\
\hline Black spruce & 690 & 299 & -- & 15 & -- & 128 & 53 \\
\hline Bal sam fir & 3,959 & 1,673 & -- & 26 & -- & 407 & 220 \\
\hline Hemlock & 1,805 & 235 & -- & 1 & -- & -- & 859 \\
\hline Tamarack & 767 & 38 & 118 & 13 & -- & -- & -- \\
\hline Northern white-cedar & 590 & 25 & -- & 3 & 65 & -- & 58 \\
\hline Other softwoods & -- & - & -- & -- & -- & -- & -- \\
\hline Total & 17,380 & 2,899 & 118 & 1,773 & 2,431 & 2,661 & 1,383 \\
\hline \multicolumn{8}{|l|}{ Hardwoods } \\
\hline Whi te oak & 321 & 2 & -- & 1 & 56 & -- & - \\
\hline Select red oak & 3,044 & 3 & -- & 1,004 & 349 & 43 & -- \\
\hline 0ther red oak & 79 & 1 & -- & -- & 75 & -- & -- \\
\hline Hickory & -- & -- & -- & -- & -- & -- & -- \\
\hline Basswood & 2,484 & 234 & 58 & 262 & 45 & 14 & -- \\
\hline Beech & & -- & -- & -- & -- & -- & -- \\
\hline Yellow birch & 1,208 & 4 & -- & 50 & -- & -- & 450 \\
\hline Hard maple & 5,004 & 1,402 & -- & 720 & -- & -- & 85 \\
\hline Soft maple & 3,115 & 374 & 64 & 1,238 & 49 & 71 & 74 \\
\hline Elm & 4,154 & 937 & -- & $\begin{array}{r}65 \\
770\end{array}$ & 142 & 115 & 74 \\
\hline Ash & 2,031 & 276 & -- & 778 & 251 & 139 & -- \\
\hline Cottonwood & -- & -- & -- & $-\overline{0}$ & -- & -- & -- \\
\hline Balsam poplar & 22 & -- & -- & 22 & -- & -- & - \\
\hline Bigtooth aspen & 9,119 & 142 & 104 & 3,159 & 1,382 & 1,637 & 304 \\
\hline Quaking aspen & 19,042 & 3,235 & 562 & 3,021 & 1,193 & 1,797 & 1,950 \\
\hline Paper birch & 4,889 & 639 & -- & 1,896 & -- & 441 & 366 \\
\hline Black cherry & 116 & -- & -- & -- & -- & -- & -- \\
\hline Black walnut & -- & -- & -- & -- & -- & -- & - \\
\hline Butternut & -- & -- & -- & -- & -- & -- & -- \\
\hline Other hardwoods & -- & $=-$ & -- & - & -- & -- & -- \\
\hline Total & 54,628 & 7,249 & 788 & 12,216 & 3,542 & 4,257 & 3,303 \\
\hline All species & 72,008 & 10,148 & 906 & 13,989 & 5,973 & 6,918 & 4,686 \\
\hline
\end{tabular}


(Table 51 continued)

\begin{tabular}{|c|c|c|c|c|c|c|}
\hline \multirow[b]{2}{*}{ Species group } & \multicolumn{6}{|c|}{ County } \\
\hline & Polk & Price & Rusk & Sawyer & Taylor & Washburn \\
\hline \multicolumn{7}{|l|}{ Softwoods } \\
\hline Jack pine & 570 & 27 & - & 548 & 2 & 349 \\
\hline Red pine & -- & 1 & - & 2 & 1 & 75 \\
\hline White pine & 275 & 3 & - & 593 & 1 & $\ldots$ \\
\hline White spruce & - & 4 & -- & 3 & 52 & 34 \\
\hline Black spruce & - & 27 & - & 54 & 12 & 102 \\
\hline Balsam fir & - & 114 & $\cdots$ & 1,344 & 175 & - \\
\hline Hemlock & $\cdots$ & 2 & - & 511 & 197 & - \\
\hline Tamarack & -- & 405 & - & 27 & 8 & 158 \\
\hline Northern white-cedar & $\cdots$ & 426 & $\cdots$ & 10 & 3 & $\cdots$ \\
\hline Other softwoods & - & - & - & - & $=$ & $=$ \\
\hline Total & 845 & 1,009 & $\cdots$ & 3,092 & 451 & 718 \\
\hline \multicolumn{7}{|l|}{ Hardwoods } \\
\hline White oak & 237 & 2 & - & 1 & $\cdots$ & 22 \\
\hline Select red oak & 1,040 & 53 & 259 & 34 & - & 259 \\
\hline Other red oak & - & 2 & - & 1 & -- & -- \\
\hline Hickory & - & $\cdots$ & - & - & - & -- \\
\hline Basswood & 149 & 962 & 222 & 74 & 464 & - \\
\hline Beech & -- & - & - & - & - & - \\
\hline Yellow birch & - & 194 & 199 & 135 & 176 & -- \\
\hline Hard maple & 121 & 1,184 & 920 & 184 & 388 & $\cdots$ \\
\hline Soft maple & 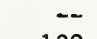 & 153 & 140 & 188 & 716 & 48 \\
\hline E $1 \mathrm{~m}$ & 192 & 959 & 795 & 40 & 835 & -- \\
\hline Ash & - & 233 & 206 & 49 & 99 & - \\
\hline Cottonwood & $\cdots$ & $\cdots$ & - & $\cdots$ & $\cdots$ & - \\
\hline Balsam poplar & $\ddot{30}$ & $=$ & $\cdots$ & $-\bar{c}$ & $=$ & 25 \\
\hline Bigtooth aspen & 348 & 165 & - & 966 & 62 & $\begin{array}{r}850 \\
2187\end{array}$ \\
\hline Quaking aspen & 43 & 1,387 & 157 & 1,887 & 1,666 & 2,181 \\
\hline $\begin{array}{l}\text { Paper birch } \\
\text { Black cherry }\end{array}$ & - & $\begin{array}{r}302 \\
58\end{array}$ & 426 & 428 & $\begin{array}{r}139 \\
18\end{array}$ & 209 \\
\hline $\begin{array}{l}\text { Black cherry } \\
\text { Black walnut }\end{array}$ & $\ldots$ & $\begin{array}{l}58 \\
-\end{array}$ & $\cdots$ & 40 & 18 & $\cdots$ \\
\hline $\begin{array}{l}\text { Black walnut } \\
\text { Butternut }\end{array}$ & - & $\ldots$ & $\ldots$ & $\cdots$ & $\ldots$ & $\ldots$ \\
\hline Other hardwoods & - & $\ldots$ & - & - & $\ldots$ & $\ldots$ \\
\hline Total & 2,130 & 5,654 & 3,324 & 4,027 & 4,563 & 3,575 \\
\hline All species & 2,975 & 6,663 & 3,324 & 7,119 & 5,014 & 4,293 \\
\hline
\end{tabular}


Table 52.--Average annual sawtimber removals on commercial forest land by species group and county, Northwest Unit, Wisconsin, 1967-1982

(In thousand board feet per year) $\underline{1}$ '

\begin{tabular}{|c|c|c|c|c|c|c|c|}
\hline \multirow[b]{2}{*}{ Species group } & \multirow{2}{*}{$\begin{array}{c}\text { Al1 } \\
\text { counties }\end{array}$} & \multicolumn{6}{|c|}{ County } \\
\hline & & Ashl and & Barron & Bayfield & Burnett & Douglas & Iron \\
\hline \multicolumn{8}{|l|}{ Softwoods } \\
\hline Jack pine & 11,362 & 5 & -- & 1,539 & 2,709 & 2,226 & -- \\
\hline Red pine & 1,885 & -- & -- & 929 & -- & -- & 524 \\
\hline White pine & 6,469 & 2 & -- & 1,416 & 266 & -- & -- \\
\hline White spruce & 3,582 & 1,795 & -- & 834 & -- & -- & 518 \\
\hline Black spruce & 859 & 859 & -- & -- & -- & -- & -- \\
\hline Balsam fir & 9,806 & 3,594 & -- & 2 & -- & 1,476 & 207 \\
\hline Hemlock & 6,096 & 1,065 & -- & -- & -- & -- & 4,166 \\
\hline Tamarack & 2,001 & 4 & 638 & 1 & -- & -- & -- \\
\hline Northern white-cedar & 716 & 3 & -- & 1 & -- & -- & 231 \\
\hline Other softwoods & -- & -- & -- & -- & -- & -- & - \\
\hline Total & 42,776 & 7,327 & 638 & 4,722 & 2,975 & 3,702 & 5,646 \\
\hline \multicolumn{8}{|l|}{ Hardwoods } \\
\hline White oak & 553 & 2 & -- & -- & -- & -- & -- \\
\hline Select red oak & 10,070 & 1 & -- & 2,461 & 269 & -- & -- \\
\hline Other red oak & 340 & 1 & -- & -- & 336 & -- & -- \\
\hline Hickory & $\overline{-}$ & -- & -- & -- & -- & -- & 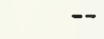 \\
\hline Basswood & 9,019 & 999 & -- & 1,499 & -- & -- & -- \\
\hline Beech & -- & -- & -- & -- & -- & -- & -- \\
\hline Yellow birch & 4,827 & 2 & -- & 281 & -- & -- & 2,609 \\
\hline Hard maple & 13,484 & 4,268 & -- & 984 & -- & $\cdots$ & 271 \\
\hline Soft maple & 2,137 & 526 & -- & 540 & -- & -- & -- \\
\hline Elm & 16,812 & 4,483 & -- & 2 & -- & 208 & 381 \\
\hline Ash & 4,071 & 1,553 & -- & 408 & -- & -- & -- \\
\hline Cottonwood & -- & -- & -- & -- & -- & -- & -- \\
\hline Balsam poplar & $\because$ & -- & -- & $\because-$ & $\ddot{-}$ & -- & -- \\
\hline Bigtooth aspen & 21,740 & -- & 572 & 9,546 & 3,248 & -- & 1,687 \\
\hline Quaking aspen & 42,820 & 7,779 & 1,846 & 8,464 & 1,178 & 2,627 & 2,914 \\
\hline Paper birch & 13,332 & 3,467 & -- & 6,215 & -- & 733 & 654 \\
\hline Black cherry & 379 & -- & - & -- & -- & -- & -- \\
\hline Black walnut & -- & -- & -- & -- & -- & -- & -- \\
\hline Butternut & -- & -- & -- & -- & -- & -- & -- \\
\hline Other hardwoods & -- & - & -- & -- & -- & - & - \\
\hline Total & 139,584 & 23,081 & 2,418 & 30,400 & 5,031 & 3,568 & 8,516 \\
\hline All species & 182,360 & 30,408 & 3,056 & 35,122 & 8,006 & 7,270 & 14,162 \\
\hline
\end{tabular}




\begin{tabular}{|c|c|c|c|c|c|c|}
\hline \multirow[b]{2}{*}{ Species group } & \multicolumn{6}{|c|}{ County } \\
\hline & Polk & Price & Rusk & Sawyer & Taylor & Washburn \\
\hline \multicolumn{7}{|l|}{ Softwoods } \\
\hline Jack pine & 1,752 & 79 & -- & 2,286 & 2 & 764 \\
\hline Red pine & -- & -- & -- & -- & -- & 432 \\
\hline White pine & 1,611 & 1 & -- & 3,173 & -- & -- \\
\hline White spruce & -- & 3 & -- & 1 & 265 & 166 \\
\hline Black spruce & -- & -- & -. & -- & -- & - \\
\hline Balsam fir & -- & 256 & -- & 3,952 & 319 & -- \\
\hline Hemlock & -- & -- & -- & -- & 865 & -- \\
\hline Tamarack & -- & 1,185 & -- & 3 & 1 & 169 \\
\hline Northern white-cedar & -- & 480 & -- & 1 & -- & -- \\
\hline Other softwoods & -- & -- & -- & -- & -- & -- \\
\hline Total & 3,363 & 2,004 & -- & 9,416 & 1,452 & 1,531 \\
\hline \multicolumn{7}{|l|}{ Hardwoods } \\
\hline White oak & 548 & 2 & -- & 1 & -- & -- \\
\hline Select red oak & 5.775 & 297 & 992 & -- & -- & 275 \\
\hline Other red oak & -- & 2 & -- & 1 & - & - \\
\hline Hickory & -- & -- & -- & -- & -- & -- \\
\hline Basswood & 832 & 2,896 & 1,259 & 1 & 1,533 & -- \\
\hline Beech & -- & -- & -- & -- & -- & -- \\
\hline Yellow birch & -- & 365 & 1,144 & 1 & 425 & -- \\
\hline Hard maple & 704 & 1,003 & 3,797 & 666 & 1,791 & -- \\
\hline Soft maple & -- & 278 & -- & 6 & 787 & - \\
\hline Elm & 988 & 4,496 & 3,118 & 3 & 3,133 & -- \\
\hline Ash & -- & 566 & 898 & 12 & 634 & $=-$ \\
\hline Cottonwood & -- & -- & -- & -- & -- & -- \\
\hline Balsam poplar & -- & -- & -- & -- & -- & -- \\
\hline Bigtooth aspen & 1,919 & 293 & -- & 3,470 & 340 & 665 \\
\hline Quaking aspen & -- & 2,155 & 303 & 4,947 & 4,404 & 6203 \\
\hline Paper birch & -- & 10 & 939 & 276 & 597 & 441 \\
\hline Black cherry & -- & 379 & - & - & - & - \\
\hline Black walnut & -- & -- & -- & -- & -- & -- \\
\hline Butternut & -- & -- & -- & -- & -- & -- \\
\hline Other hardwoods & -- & -- & - & -- & $\cdots$ & -- \\
\hline Total & 10,766 & 12,742 & 12,450 & 9,384 & 13,644 & 7,584 \\
\hline All species & 14,129 & 14,746 & 12,450 & 18,800 & 15,096 & 9,115 \\
\hline
\end{tabular}


Table 53.--Current annual growing-stock and sawtimber removals on commercial forest land by species group, Northwest Unit, Wisconsin, 1967 and 1982

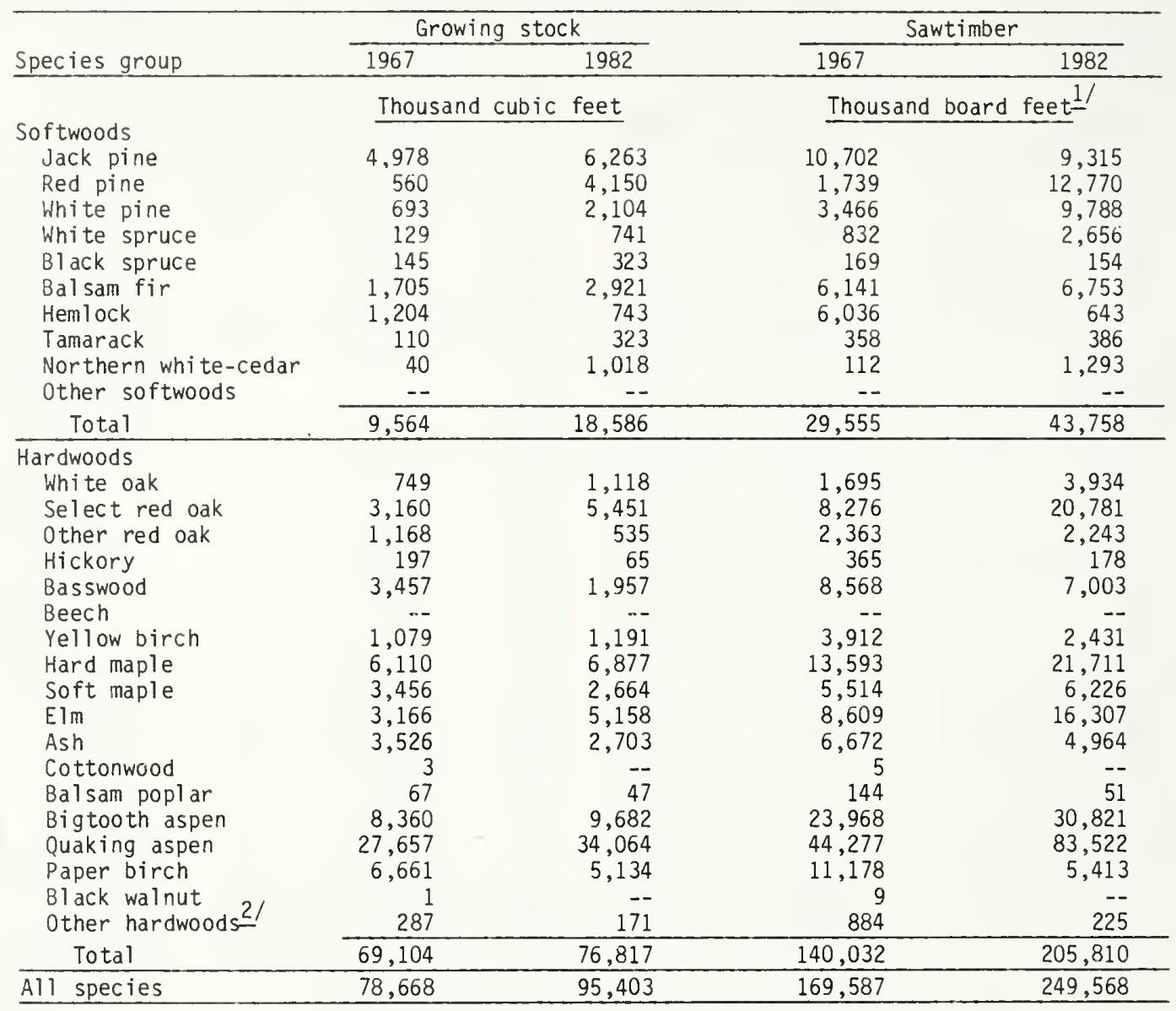

$1 /$ International $1 / 4$-inch rule.

2/ Includes black cherry and butternut. 


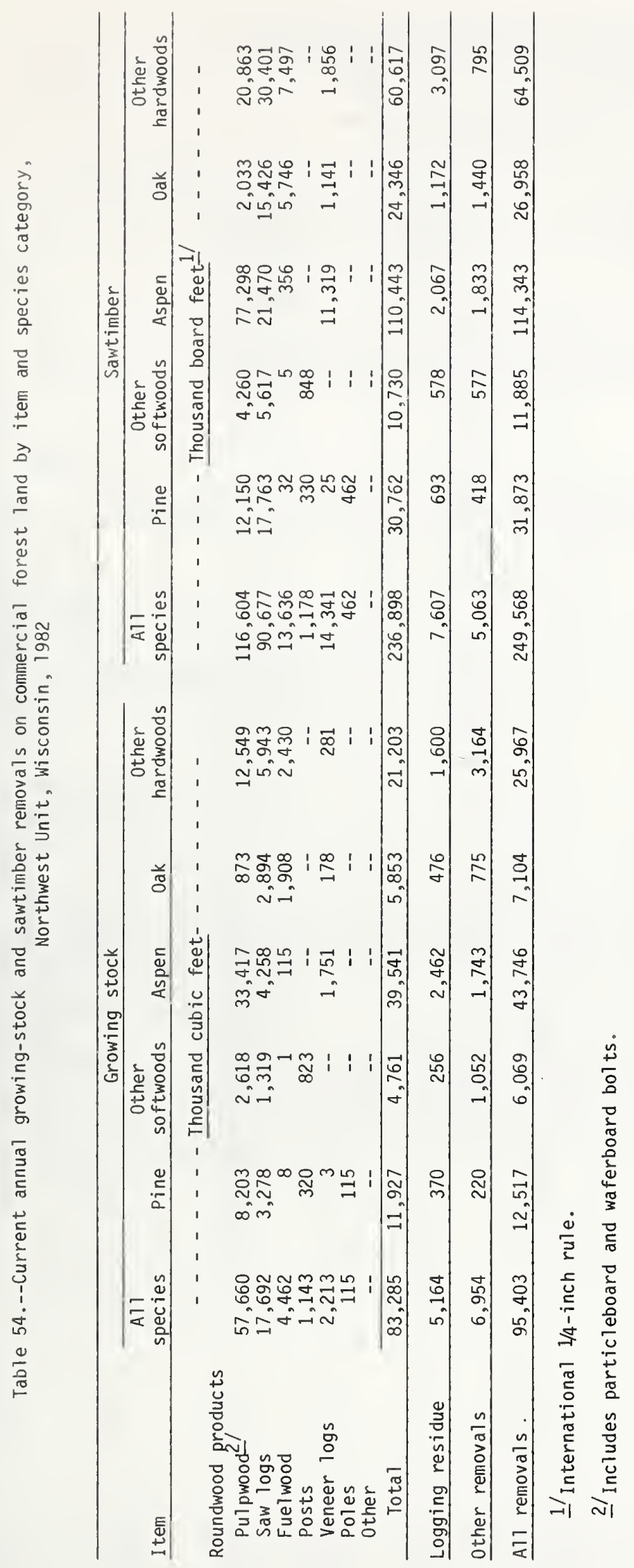


Table 55.--Annual mortality of growing stock on commercial forest 1 and by softwoods and hardwoods, Northwest Unit, Wisconsin, 1967 and 1982

(In thousand cubic feet)

\begin{tabular}{lrc}
\hline Species & $1967^{\underline{1}}$ & 1982 \\
\hline Softwoods & 7,000 & 10,298 \\
Hardwoods & 28,000 & 38,613 \\
\cline { 2 - 3 } Total & 35,000 & 48,911 \\
\hline
\end{tabular}

1/Figures have been adjusted from those pub1 ished after the 1968 survey to conform to 1982 volumes because of changes in survey procedures.

Table 56.--Annual mortality of growing stock on commercial forest land by species group and cause, Northwest Unit, Wisconsin, 1982

(In thousand cubic feet)

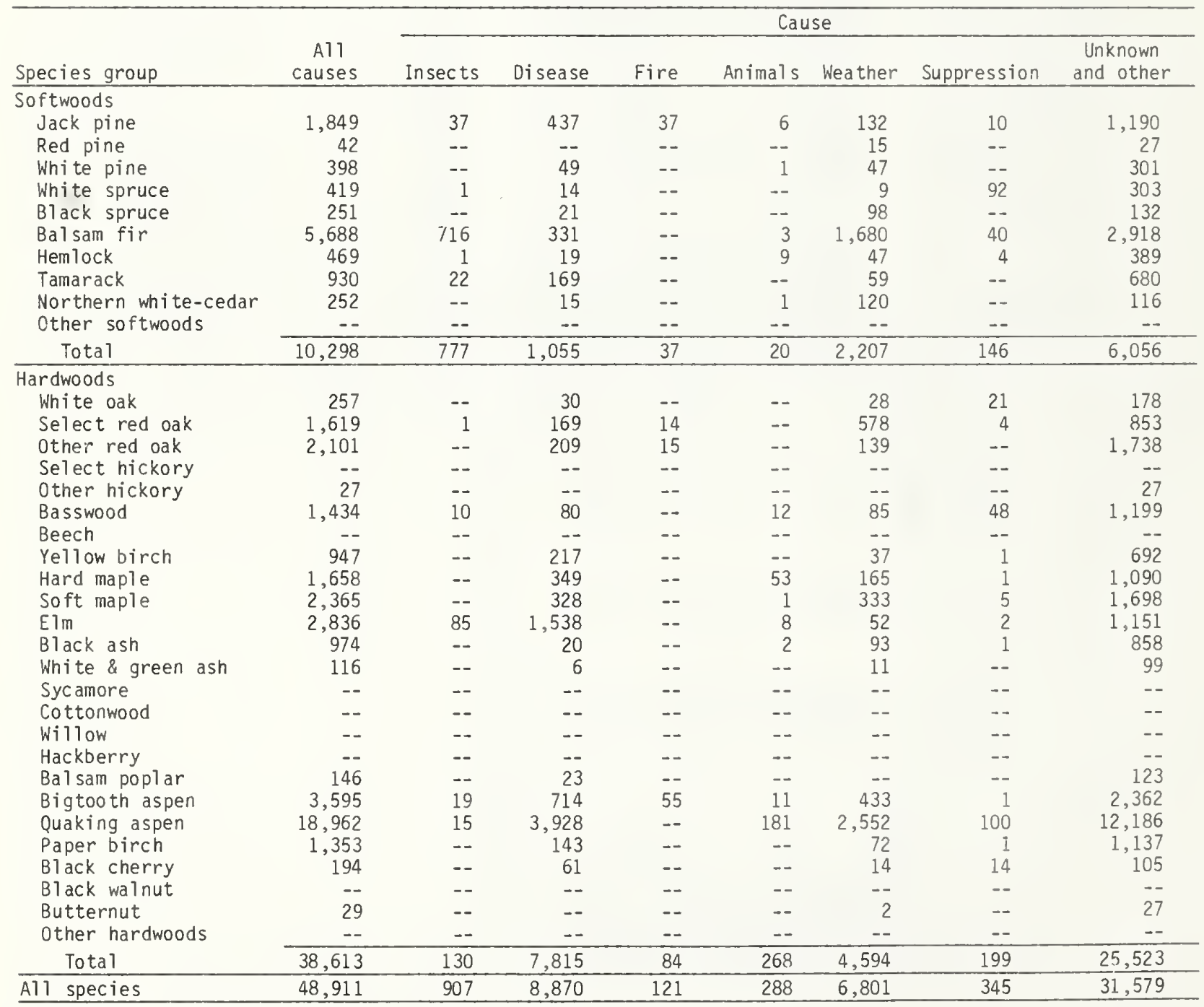


Table 57.--Annual mortality of sawtimber on commercial forest land by species group and cause, Northwest Unit, Wi sconsin, 1982

(In thousand board feet) 1 '

\begin{tabular}{|c|c|c|c|c|c|c|c|c|}
\hline \multirow[b]{2}{*}{ Species group } & \multirow[b]{2}{*}{$\begin{array}{c}\text { All } \\
\text { causes }\end{array}$} & \multicolumn{7}{|c|}{ Cause } \\
\hline & & Insects & Disease & Fire & Animals & Wea ther & Suppression & $\begin{array}{l}\text { Unknown } \\
\text { and other }\end{array}$ \\
\hline \multicolumn{9}{|l|}{ Softwoods } \\
\hline Jack pine & 1,800 & 57 & 144 & -- & 20 & 569 & -- & 1,010 \\
\hline Red pine & 157 & -- & -- & -- & -- & 86 & -- & \\
\hline White pine & 1,590 & 3 & 238 & -- & 4 & 300 & -- & 1,045 \\
\hline White spruce & 794 & $g$ & 44 & -- & -- & 7 & -- & 734 \\
\hline Black spruce & 95 & -- & 4 & -- & -- & 88 & -- & 3 \\
\hline Bal sam fir & 8,939 & 74 & 1,161 & -- & 6 & 2,646 & 3 & 5,049 \\
\hline Hemlock & 1,935 & 8 & 89 & -- & 33 & 210 & 14 & 1,581 \\
\hline Tamarack & 793 & - & 91 & -- & -- & 6 & -- & 696 \\
\hline Northern white-cedar & 802 & -- & 110 & -- & 5 & 238 & -- & 449 \\
\hline Other softwoods & -- & -- & - & -- & -- & -- & -- & -- \\
\hline Total & 16,905 & 151 & 1,881 & -- & 68 & 4,150 & 17 & 10,638 \\
\hline \multicolumn{9}{|l|}{ Hardwoods } \\
\hline Whi te oak & 480 & -- & 150 & -- & 3 & 38 & 3 & 286 \\
\hline Select red oak & 2,404 & -- & 363 & -- & -- & 554 & -- & 1,487 \\
\hline other red oak & 1,244 & -- & 175 & 65 & -- & 136 & -- & 868 \\
\hline Select hickory & - & -- & -- & -- & -. & $\ldots$ & -- & -- \\
\hline Other hickory & 13 & -- & 7 & -- & -- & -- & -- & 6 \\
\hline Basswood & 2,526 & 24 & 223 & -- & 38 & 261 & - & 1,980 \\
\hline Beech & - & -- & -- & -- & -- & -- & -- & -- \\
\hline Yellow birch & 2,685 & -- & 635 & -- & -- & 127 & -- & 1,923 \\
\hline Hard maple & 2,218 & -- & 597 & -- & 6 & 427 & -- & 1,188 \\
\hline Soft maple & 2,038 & -- & 367 & -- & -- & 359 & -- & 1,312 \\
\hline Elm & 7,310 & 139 & 4,194 & -- & 25 & 202 & -- & 2,750 \\
\hline Black ash & 974 & -- & 19 & -- & - & 127 & -- & 828 \\
\hline White \& green ash & 236 & -- & 17 & -- & -- & 5 & -- & 214 \\
\hline Syc amore & -- & -- & -- & -- & -- & -- & -- & -- \\
\hline Cottonwood & -- & -- & -- & -- & -- & -- & -- & -- \\
\hline Willow & -- & -- & -- & -- & -- & -- & -- & -- \\
\hline Hackberry & -- & -- & -- & -- & - & -- &.- & -- \\
\hline Bal sam poplar & 262 & -- & 52 & -- & -- & -- & -- & 210 \\
\hline Bigtooth aspen & 7,157 & 96 & 1,381 & -- & 42 & 1,887 & -- & 3,751 \\
\hline Quaking aspen & 24,658 & -- & 6,241 & -- & 140 & 4,406 & -- & 13,871 \\
\hline Paper birch & 664 & -- & 120 & -- & -. & 63 & -- & 481 \\
\hline Bl ack cherry & 23 & -- & -- & -- & -- & - & -- & 23 \\
\hline Black walnut & -- & -- & -- & -- & -- & -- & -- & - \\
\hline Butternut & 10 & -- & 4 & -- & -- & -- & -- & 6 \\
\hline Other hardwoods & -- & -- & -- & -- & -- & -- & -- & -- \\
\hline Total & 54,902 & 259 & 14,545 & 65 & 254 & 8,592 & 3 & 31,184 \\
\hline All species & 71,807 & 410 & 16,426 & 65 & 322 & 12,742 & 20 & 41,822 \\
\hline
\end{tabular}

1/International $1 / 4$-inch rule. 
Table 58.--Annual mortality of growing stock and sawtimber on commercial forest land by county and softwoods and hardwoods, Northwest Unit, Wi sconsin, 1982

\begin{tabular}{|c|c|c|c|c|c|c|}
\hline \multirow[b]{2}{*}{ County } & \multicolumn{3}{|c|}{ Growing stock } & \multicolumn{3}{|c|}{ Sawtimber } \\
\hline & $\begin{array}{c}\text { All } \\
\text { species }\end{array}$ & So ftwoods & Hardwoods & $\begin{array}{c}\text { All } \\
\text { species }\end{array}$ & So f twoods & Hardwoods \\
\hline & --- & usand cubic & et --- & $--I$ & sand board & $t \frac{1 /}{1 /}$. \\
\hline $\begin{array}{l}\text { Ashl and } \\
\text { Barron } \\
\text { Bayfield } \\
\text { Burnett } \\
\text { Douglas } \\
\text { Iron } \\
\text { Polk } \\
\text { Price } \\
\text { Rusk } \\
\text { Sawyer } \\
\text { Taylor } \\
\text { Washburn }\end{array}$ & $\begin{array}{l}6,278 \\
1,524 \\
7,659 \\
3,277 \\
5,132 \\
3,283 \\
2,283 \\
5,057 \\
3,368 \\
4,941 \\
2,874 \\
3,235 \\
\end{array}$ & $\begin{array}{r}2,981 \\
5 \\
1,683 \\
428 \\
1,210 \\
710 \\
56 \\
1,302 \\
178 \\
731 \\
527 \\
487 \\
\end{array}$ & $\begin{array}{l}3,297 \\
1,519 \\
5,976 \\
2,849 \\
3,922 \\
2,573 \\
2,227 \\
3,755 \\
3,190 \\
4,210 \\
2,347 \\
2,748 \\
\end{array}$ & $\begin{array}{r}8,704 \\
2,508 \\
10,857 \\
4,392 \\
7,090 \\
5,829 \\
2,874 \\
8,933 \\
4,522 \\
7,984 \\
3,966 \\
4,148 \\
\end{array}$ & $\begin{array}{r}2,862 \\
11 \\
3,142 \\
712 \\
2,120 \\
1,819 \\
36 \\
3,279 \\
374 \\
1,349 \\
638 \\
563 \\
\end{array}$ & $\begin{array}{l}5,842 \\
2,497 \\
7,715 \\
3,680 \\
4,970 \\
4,010 \\
2,838 \\
5,654 \\
4,148 \\
6,635 \\
3,328 \\
3,585\end{array}$ \\
\hline
\end{tabular}

$1 /$ International $1 / 4$-inch rule.

Table 59.--Annual mortality of growing stock and sawtimber on commercial forest land by ownership class and softwoods and hardwoods, Northwest Unit, Wisconsin, 1982

\begin{tabular}{|c|c|c|c|c|c|c|}
\hline \multirow[b]{2}{*}{ Ownership class } & \multicolumn{3}{|c|}{ Growing stock } & \multicolumn{3}{|c|}{ Sawtimber } \\
\hline & $\begin{array}{c}\text { All } \\
\text { species }\end{array}$ & Softwoods & Hardwoods & $\begin{array}{c}\text { All } \\
\text { species }\end{array}$ & So ftwoods & Hardwoods \\
\hline & $-\ldots$ & sand cubic & et - - - & $-\ldots I$ & sand board & $t \underline{1 /}-\cdots$ \\
\hline $\begin{array}{l}\text { National Forest } \\
\text { Miscellaneous federal } \\
\text { State } \\
\text { County and municipal } \\
\text { Indian } \\
\text { Forest industry } \\
\text { Farmer } \\
\text { Misc. private-corp. }\end{array}$ & $\begin{array}{r}8,289 \\
45 \\
1,509 \\
10,439 \\
1,235 \\
3,777 \\
4,630 \\
2,268\end{array}$ & $\begin{array}{r}4,650 \\
-- \\
241 \\
1,774 \\
173 \\
800 \\
381 \\
205\end{array}$ & $\begin{array}{r}3,639 \\
45 \\
1,268 \\
8,665 \\
1,062 \\
2,977 \\
4,249 \\
2,063\end{array}$ & $\begin{array}{r}11,949 \\
85 \\
2,641 \\
15,023 \\
2,400 \\
5,846 \\
7,034 \\
3,427\end{array}$ & $\begin{array}{r}5,241 \\
-- \\
498 \\
4,093 \\
647 \\
1,731 \\
611 \\
350\end{array}$ & $\begin{array}{r}6,708 \\
85 \\
2,143 \\
10,930 \\
1,753 \\
4,115 \\
6,423 \\
3,077\end{array}$ \\
\hline Misc. private-indiv. & 16,719 & 2,074 & 14,645 & 23,402 & 3,734 & 19,668 \\
\hline All owners & 48,911 & 10,298 & 38,613 & 71,807 & 16,905 & 54,902 \\
\hline
\end{tabular}

1/International $1 / 4-i n c h$ rule. 


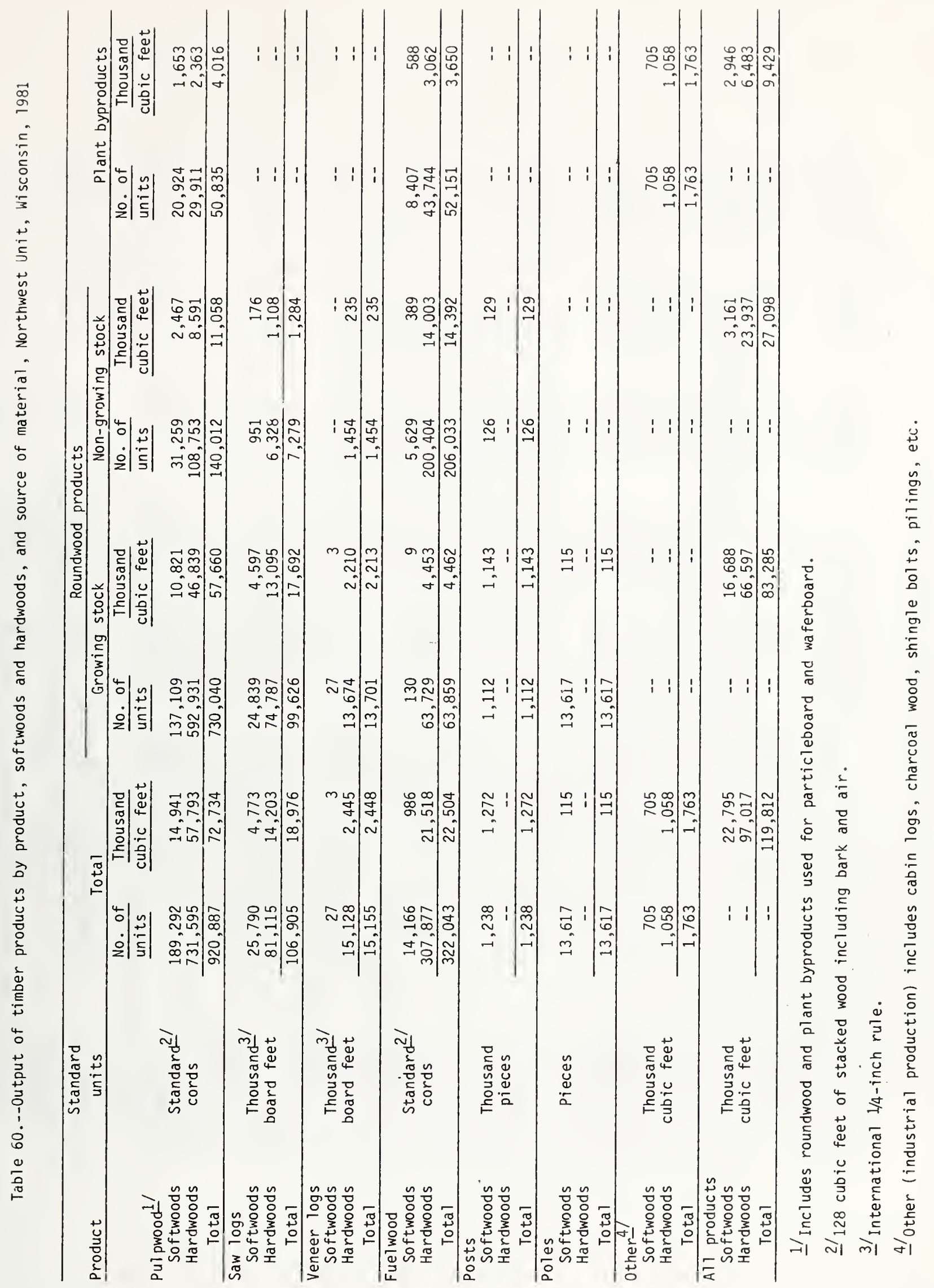




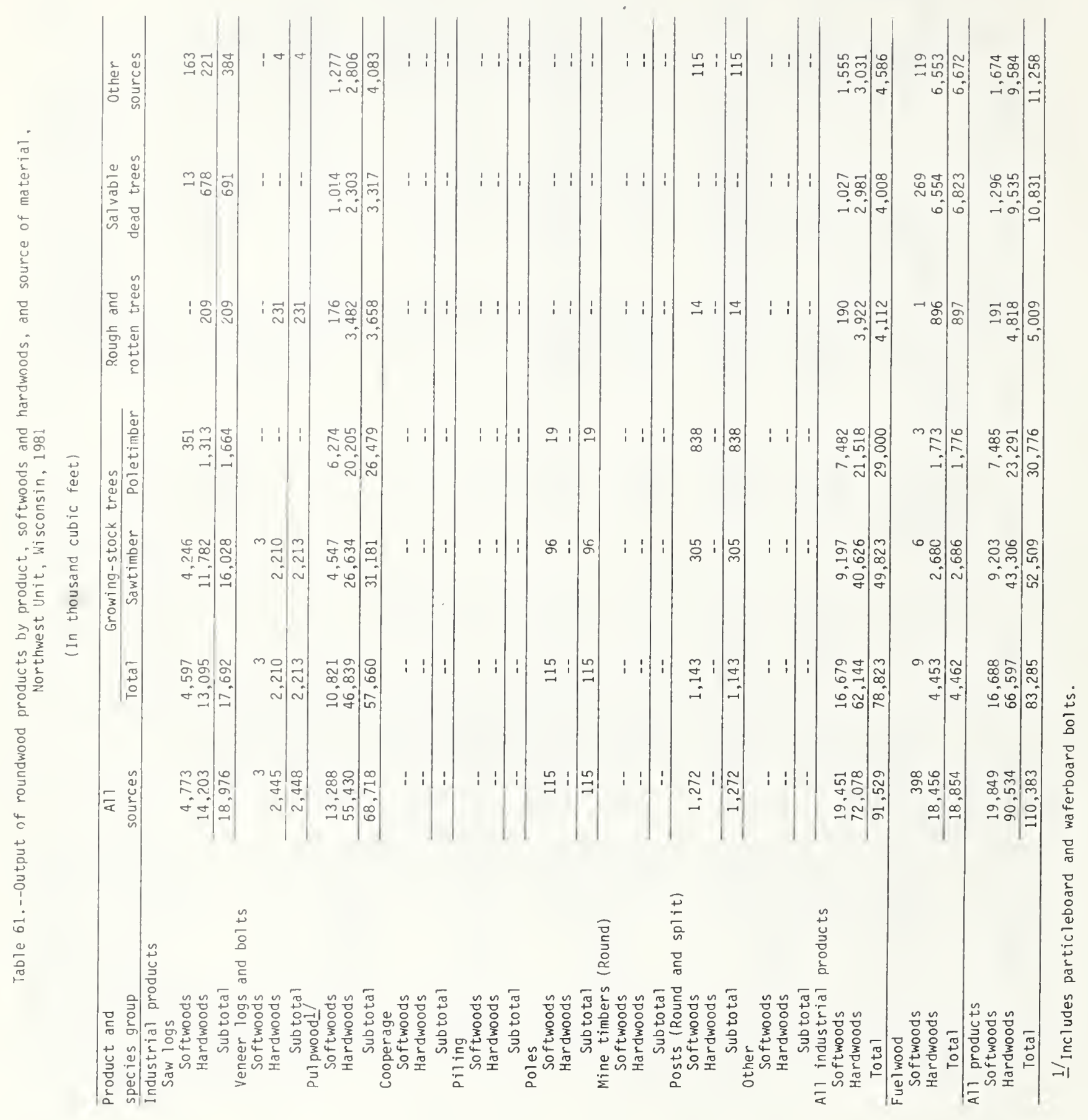




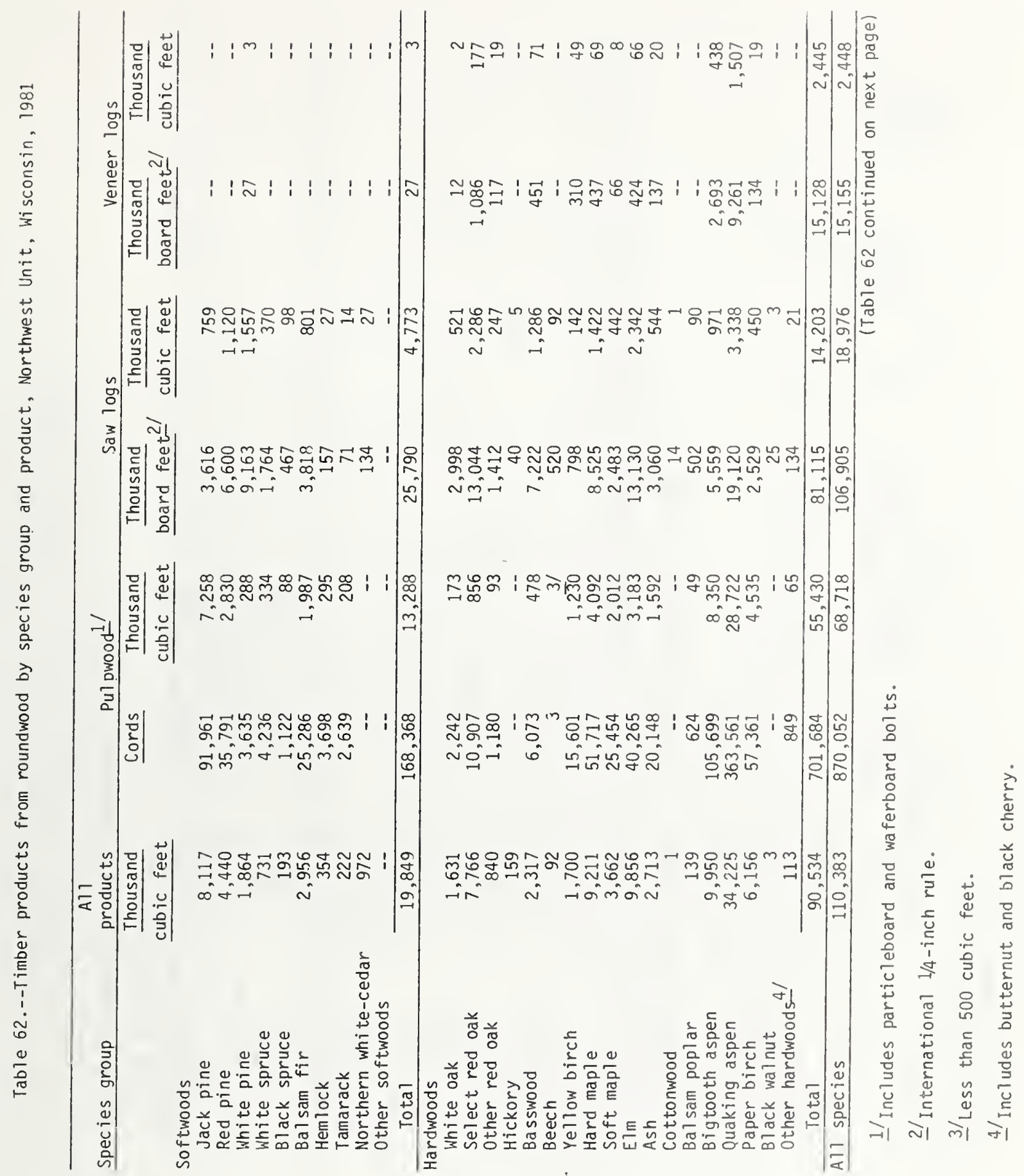




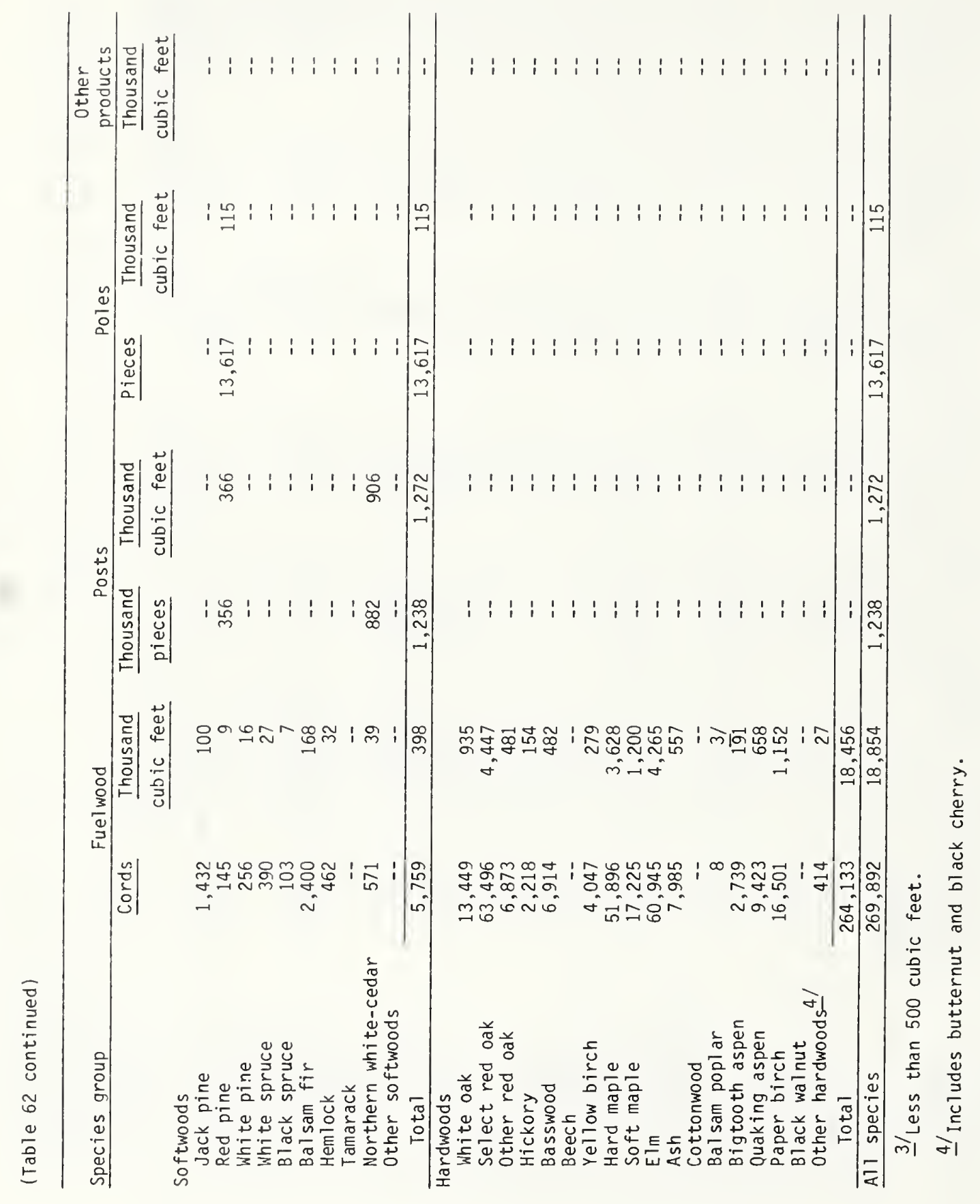




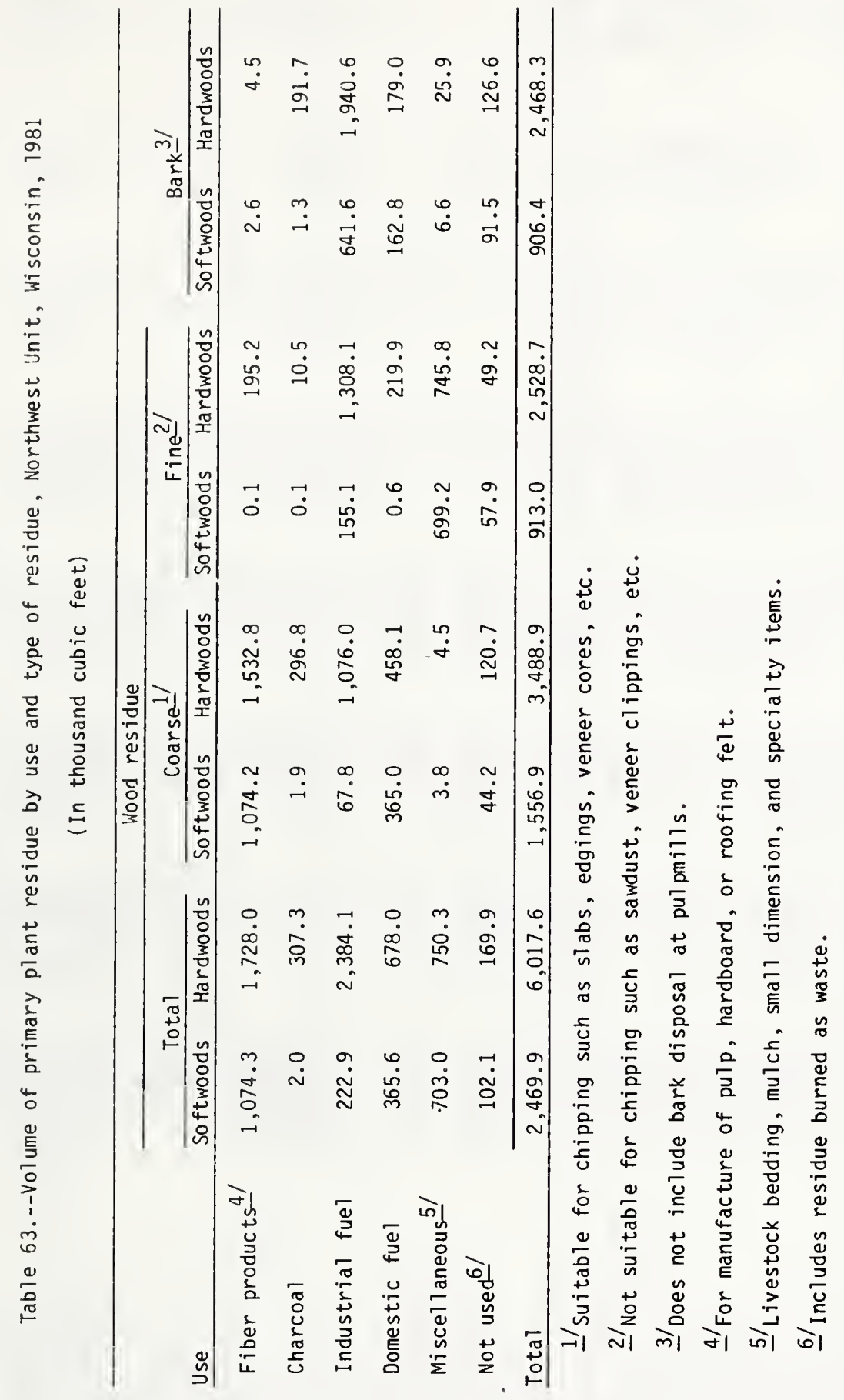




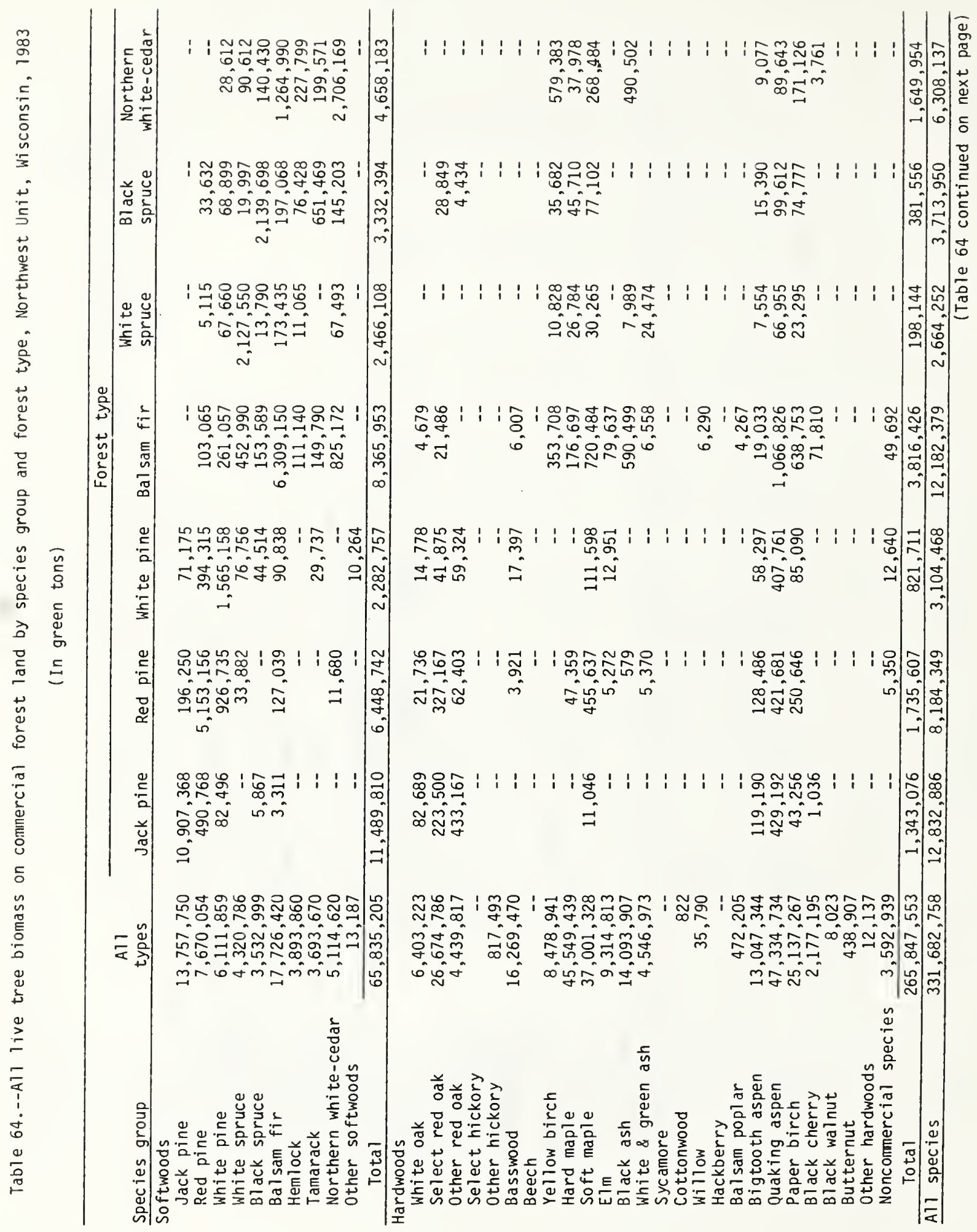




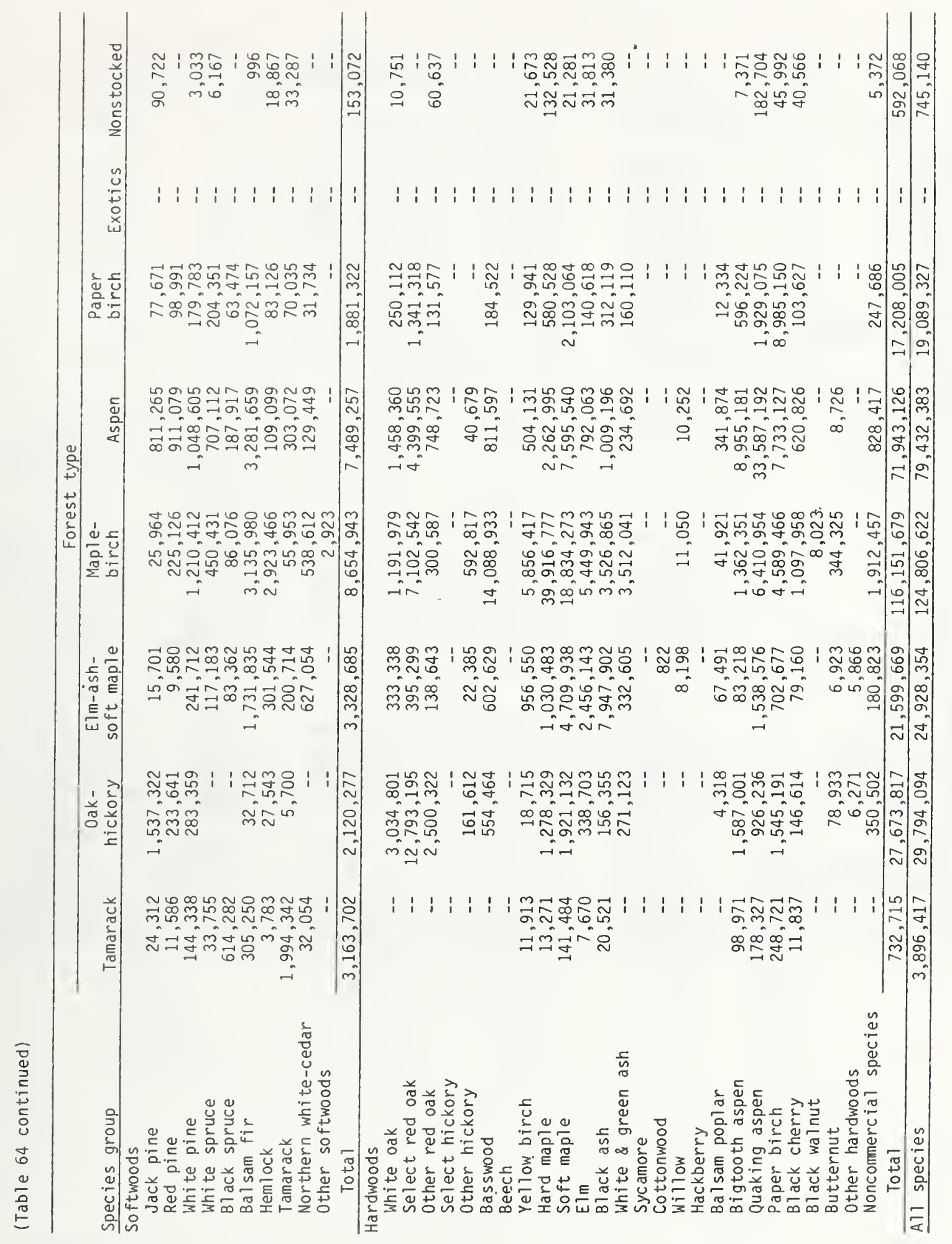


Table 65.--All live tree biomass by species group and tree biomass component, Northwest Unit, Wisconsin, 1983

(In green tons)

\begin{tabular}{|c|c|c|c|c|c|c|}
\hline \multirow[b]{3}{*}{ Species group } & \multirow[b]{3}{*}{$\begin{array}{c}\text { All } \\
\text { components }\end{array}$} & \multicolumn{5}{|c|}{ Biomass component } \\
\hline & & \multirow{2}{*}{$\begin{array}{l}\text { All live } \\
\text { 1- to 5-inch } \\
\text { trees }\end{array}$} & \multicolumn{2}{|c|}{ Growing stock } & \multicolumn{2}{|c|}{ Cull } \\
\hline & & & Boles & $\begin{array}{c}\text { Tops and } \\
\text { Timbs }\end{array}$ & Boles & $\begin{array}{c}\text { Tops and } \\
1 \text { imbs }\end{array}$ \\
\hline \multirow[t]{2}{*}{$\begin{array}{l}\text { So ftwoods } \\
\text { Jack pine } \\
\text { Red pine } \\
\text { White pine } \\
\text { White spruce } \\
\text { Black spruce } \\
\text { Bal sam fir } \\
\text { Hemlock } \\
\text { Tamarack } \\
\text { Northern white-cedar } \\
\text { Other softwoods } \\
\text { Total } \\
\end{array}$} & $\begin{array}{r}13,757,750 \\
7,670,054 \\
6,111,859 \\
4,320,786 \\
3,532,999 \\
17,726,420 \\
3,893,860 \\
3,693,670 \\
5,114,620 \\
13,187 \\
\end{array}$ & $\begin{array}{r}2,176,670 \\
693,034 \\
307,812 \\
434,498 \\
2,204,380 \\
5,120,100 \\
69,132 \\
1,103,072 \\
626,940 \\
-- \\
\end{array}$ & $\begin{array}{r}7,609,521 \\
4,814,788 \\
3,721,056 \\
2,686,586 \\
848,692 \\
8,557,069 \\
2,207,338 \\
1,694,892 \\
2,366,040 \\
9,279 \\
\end{array}$ & $\begin{array}{r}3,238,214 \\
2,074,267 \\
1,606,336 \\
1,119,050 \\
353,822 \\
3,537,137 \\
933,004 \\
711,979 \\
965,276 \\
3,908 \\
\end{array}$ & $\begin{array}{r}526,304 \\
61,522 \\
332,663 \\
62,363 \\
107,764 \\
396,637 \\
486,729 \\
134,524 \\
840,452 \\
- \\
\end{array}$ & $\begin{array}{r}207,041 \\
26,443 \\
143,992 \\
18,289 \\
18,341 \\
115,477 \\
197,657 \\
49,203 \\
315,912 \\
-\end{array}$ \\
\hline & $65,835,205$ & $12,735,638$ & $34,515,261$ & $14,542,993$ & $2,948,958$ & $1,092,355$ \\
\hline \multicolumn{7}{|l|}{ Hardwoods } \\
\hline $\begin{array}{l}\text { White oak } \\
\text { Select red oak } \\
\text { Other red oak }\end{array}$ & $\begin{array}{r}6,403,223 \\
26,674,786 \\
4,439,817\end{array}$ & $\begin{array}{r}574,364 \\
1,283,896 \\
151,914\end{array}$ & $\begin{array}{r}3,050,691 \\
15,676,248 \\
1,709,730\end{array}$ & $\begin{array}{r}1,264,699 \\
6,642,616 \\
714,336\end{array}$ & $\begin{array}{l}1,102,011 \\
2,175,517 \\
1,358,236\end{array}$ & $\begin{array}{l}411,458 \\
896,509 \\
505,601\end{array}$ \\
\hline $\begin{array}{l}\text { Select hickory } \\
\text { other hickory } \\
\text { Basswood }\end{array}$ & $\begin{array}{r}817,493 \\
16,269,470\end{array}$ & $\begin{array}{l}141,516 \\
799,378\end{array}$ & $\begin{array}{r}400,189 \\
9,784,105\end{array}$ & $\begin{array}{r}170,105 \\
4,145,454\end{array}$ & $\begin{array}{r}80,743 \\
1,100,584\end{array}$ & $\begin{array}{r}24,940 \\
439,949\end{array}$ \\
\hline Beech & -- & -- & -- & -- & -- & -- \\
\hline $\begin{array}{l}\text { Yellow birch } \\
\text { Hard maple }\end{array}$ & $\begin{array}{r}8,478,941 \\
45,549,439\end{array}$ & $\begin{array}{r}739,138 \\
7,526,665\end{array}$ & $\begin{array}{r}3,269,882 \\
20,104,517\end{array}$ & $\begin{array}{l}1,367,331 \\
8,515,846\end{array}$ & $\begin{array}{l}2,250,602 \\
6,804,001\end{array}$ & $\begin{array}{r}851,988 \\
2,598,410\end{array}$ \\
\hline $\begin{array}{l}\text { Soft maple } \\
\text { Elm } \\
\text { Black ash } \\
\text { White \& green ash }\end{array}$ & $\begin{array}{r}37,001,328 \\
9,314,813 \\
14,093,907 \\
4,546,973\end{array}$ & $\begin{array}{r}9,409,836 \\
679,829 \\
2,351,888 \\
253,755\end{array}$ & $\begin{array}{r}14,599,455 \\
5,089,631 \\
7,407,553 \\
2,669,745\end{array}$ & $\begin{array}{l}6,202,839 \\
2,117,019 \\
3,097,957 \\
1,135,504\end{array}$ & $\begin{array}{r}5,004,810 \\
1,031,080 \\
948,355 \\
352,189\end{array}$ & $\begin{array}{r}1,784,388 \\
397,254 \\
288,154 \\
135,780\end{array}$ \\
\hline Sycamore & -- & -- & -- & - & -- & -. \\
\hline $\begin{array}{l}\text { Cottonwood } \\
\text { Willow }\end{array}$ & $\begin{array}{r}822 \\
35,790\end{array}$ & $\begin{array}{r}822 \\
--\end{array}$ & $5,7 \overline{89}$ & 2,409 & 21,234 & 6,358 \\
\hline Hackberry & $=$ & -- & -- & -- & $\begin{aligned} 21,204 \\
--\end{aligned}$ & 0 \\
\hline Balsam poplar & 472,205 & 101,923 & 230,089 & 98,935 & 28,816 & 12,442 \\
\hline Bigtooth aspen & $13,047,344$ & 915,895 & $7,694,142$ & $3,341,992$ & 783,444 & 311,871 \\
\hline Quaking aspen & $47,334,734$ & $6,074,439$ & $24,590,710$ & $10,576,858$ & $4,338,066$ & $1,754,661$ \\
\hline Paper birch & $25,137,267$ & $3,161,542$ & $13,758,213$ & $5,851,178$ & $1,739,463$ & 626,871 \\
\hline Black cherry & $2,177,195$ & 321,896 & 694,705 & 296,074 & 617,720 & 246,800 \\
\hline Black walnut & 8,023 & -- & -- & -- & 5,616 & 2,407 \\
\hline Butternut & 438,907 & 29,573 & 169,276 & 71,989 & 117,908 & 50,161 \\
\hline Other hardwoods & 12,137 & -- & 4,141 & 1,725 & 4,433 & 1,838 \\
\hline Noncommercial species & $3,592,939$ & -- & -- & -- & $3,351,062$ & 241,877 \\
\hline Total & $265,847,553$ & $34,518,269$ & $130,908,811$ & $55,614,866$ & $33,215,890$ & $11,589,717$ \\
\hline All species & $331,682,758$ & $47,253,907$ & $165,424,072$ & $70,157,859$ & $36,164,848$ & $12,682,072$ \\
\hline
\end{tabular}


Table 66.--Sampling errors/ for estimates smaller than the Unit totals of volume, net growth, removals, and area of commercial forest land, Northwest Unit, Wisconsin, 1983

\begin{tabular}{|c|c|c|c|c|c|c|c|}
\hline \multirow{2}{*}{$\begin{array}{l}\text { Sampl ing } \\
\text { error }\end{array}$} & \multirow{2}{*}{$\begin{array}{l}\text { Commercial } \\
\text { forest land }\end{array}$} & \multicolumn{3}{|c|}{ Growing stock } & \multicolumn{3}{|c|}{ Sawtimber } \\
\hline & & Inventory & Growth & Removals & Inventory & Growth & Removals \\
\hline \multirow[b]{2}{*}{ Percent } & Thousand & \multirow{2}{*}{\multicolumn{2}{|c|}{ - - - Thousand cubic }} & \multirow[b]{2}{*}{ feet- - - - } & \multirow{2}{*}{\multicolumn{3}{|c|}{$e t^{2 /}$}} \\
\hline & acres & & & & & & \\
\hline 1 & 677.8 & $11,945,209$ & 828,191 & $19,045,163$ & $67,150,869$ & $5,948,281$ & $76,363,039$ \\
\hline 2 & 169.4 & $2,986,302$ & 207,048 & $4,761,291$ & $16,787,717$ & $1,487,070$ & $19,090,760$ \\
\hline 3 & 75.3 & $1,327,245$ & 92,021 & $2,116,129$ & $7,461,208$ & 660,920 & $8,484,782$ \\
\hline 4 & 42.4 & 746,576 & 51,762 & $1,190,323$ & $4,196,929$ & 371,768 & $4,772,690$ \\
\hline 5 & 27.1 & 477,808 & 33,128 & 761,807 & 2.686 .035 & 237,931 & $3,054,522$ \\
\hline 10 & 6.8 & 119,452 & 8,282 & 190,452 & 671,509 & 59,483 & 763,630 \\
\hline 15 & 3.0 & 53,090 & 3,681 & 84,645 & 298,448 & 26,437 & 339,391 \\
\hline 20 & 1.7 & 29,863 & 2,070 & 47,613 & 167,877 & 14,871 & 190,908 \\
\hline 25 & 1.1 & 19,112 & 1,325 & 30,472 & 107,441 & 9,517 & 122,181 \\
\hline 50 & 0.3 & 4,778 & 331 & 7,618 & 26,860 & 2,379 & 30,545 \\
\hline 100 & 0.1 & 1,195 & 83 & 1,905 & 6,715 & 595 & 7,636 \\
\hline
\end{tabular}

$1 /$ At the 68-percent probability level.

2/International $1 / 4$-inch rule.

Table 67.--Sampling errors for county totals of growing-stock volume, net growth, removals, and area of commercial forest land, Northwest Unit, Wisconsin, 1983

(Percent of estimate)

\begin{tabular}{lcrrr}
\hline & $\begin{array}{c}\text { Commercial } \\
\text { Corest land }\end{array}$ & \multicolumn{3}{c}{ Growing stock } \\
\cline { 3 - 5 } & 1.16 & 4.29 & 6.07 & 41.01 \\
Ashland & 2.07 & 9.10 & 14.75 & 85.50 \\
Barron & 0.96 & 3.74 & 5.24 & 38.07 \\
Bayfield & 1.46 & 6.55 & 9.53 & 69.60 \\
Burnett & 1.04 & 4.68 & 6.24 & 78.36 \\
Douglas & 1.34 & 5.20 & 7.80 & 58.73 \\
Iron & 1.75 & 7.53 & 11.32 & 60.03 \\
Polk & 1.11 & 5.01 & 6.88 & 56.62 \\
Price & 1.37 & 5.71 & 7.94 & 63.96 \\
Rusk & 1.06 & 4.28 & 5.98 & 47.66 \\
Sawyer & 1.38 & 5.78 & 7.17 & 58.11 \\
Taylor & 1.44 & 6.05 & 8.62 & 74.74 \\
Washburn & 0.36 & 1.50 & 2.10 & 16.29 \\
All counties & & & & \\
\hline
\end{tabular}

\& U.S. GOVERNMENT PRINTING OFFICE: 1984-766-460/10006 

Smith, W. Brad.

Timber resource of Wisconsin's Northwest Survey Unit, 1983. Resour. Bull. NC-73. St. Paul, MN: U.S. Department of Agriculture, Forest Service, North Central Forest Experiment Station; 1984. 97 p.

The fourth inventory of the timber resource of the Northwest Wisconsin Survey Unit shows a 1.8 percent decline in commercial forest area and a 36 percent gain in growing-stock volume between 1968 and 1983. Presented are highlights and statistics on area, volume, growth, mortality, removals, utilization, and biomass.

KEY WORDS: Statistics, area, volume, growth, mortality, and removals. 


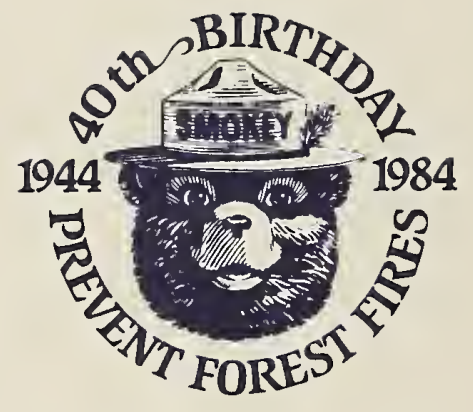

